\title{
A SHORT GUIDE \\ TO \\ CANADIAN GENERA \\ OF \\ SEED PLANTS
}

$\mathrm{Br}$

JOHN ADAMS, M.A.

DIVISION OF BOTANY

DOMINION EXPERIMENTAL FARMS

\section{DOMINION OF CANADA DEPARTMENT OF AGRICULTURE} BULLETIN NO. 78-NEW SERIES 


\title{
DOMINION EXPERIMENTAL FARMS
}

\author{
E. S. ARCHIBALD, Director
}

\section{DIVISION OF BOTANY}

\author{
H. T. GÜSSOW, Dominion Botanist
}

\section{ECONOMIC BOTANY}

Botanists

J. Adams

Junior Botanist and Librarian

H. Groh

R. A. Inglis

\section{PLANT PATHOLOGY}

Central Laboratory, Ottawa.

Plant Pathologists ........................ F. L. Drayton

Forest. B. MacCurry

Assistant Plant Pathologist...................... Irene Mounce

Charlottetown, P.E.I.

Assistant Plant Pathologist in Charge........... R. R. Hurst

Kentville, N.S.

Plant Pathologist in Charge................... J. F. Hockey

Fredericton, N.B.

Plant Pathologist in Charge................... D. J. MacLeod

Assistant Plant Pathologist.................... K. Richardson

Ste. Anne de la Pocatière, Que.

Plant Pathologist in Charge.................... N. Racicot

St. Catharines, Ont.

Plant Pathologist in Charge..................... H. Berkeley

Assistant Plant Pathologist.................... B. Jackson

Winnipeg, Man.

Senior Plant Pathologist................... D. L. Bailey

Plant Pathologists .............................. Conners

J. H. Craigie

Margaret Newton

Assistant Plant Pathologists................. F. J. Greaney

W. L. Gordon

T. Johnson

Saskatoon, Sask.

Senior Plant Pathologist in Charge............. Vacant

Plant Pathologist .............................. B. Sanford

Assistant Plant Pathologists...................... A. Scott

Indian Head, Sask.

R. C. Russell

Plant Pathologist in Charge................. P. M. Simmonds

Summerland, B.C.

Plant Pathologist in Charge................... R. McLarty 


\section{CONTENTS}

Chapter

INTRODUCTION

II Principal Subdivisions of Seed-Plants ..................... 6

III Gymosperms-Families and Genera........................ 8

IV Monocotyledons-Families and Genera.................... 9

V Monocotyledons-Araceae and Cyperaceae.................... 12

VI Monocotyledons-Gramineae........................... 14

ViI Monocotyledons-Liliaceae, Amaryllidaceae, Iridaceae, Orchidaceae. 20

Vili Apetalous Dicotyledons-Fanilies and Genera................. 24

iX Apetalous, Dicotyledons-Urticaceae, Euphorbiaceae, Polygonaceae, Amarantaceae, Chenopodiaceae ...........................

X Apetalous Dicotyledons-Salicaceae, Fagaceae, Betulaceae, Cory-

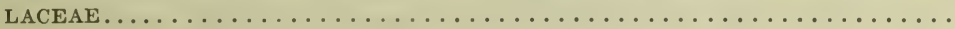

XI Choripetalous Dicotyledons-Families and Genera..............

XiI Choripetalous Dicotyledons-Ranunculaceae, Nymphaeaceae, MagNoliaceae, LaUraceae, Berberidaceae.................. \& 36

XiII Choripetalous Dicotyledons-Portulacaceae, Caryophyllaceae, Papaveraceae, Fumartaceae, Cruciferae.....................

XiV Choripetalous Dicotyledons-Cistaceae, Malvaceae, Rosaceae.....

XV Choripetalous Dicotyledons-Fabaceae, Rutaceae, Violaceae, Saxi-

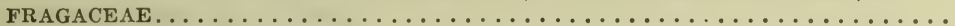

XVi Choripetalous Dicotyledons-Cactaceae, Oenotheraceae, Araliaceae, UMbelLIFERAE......................................

XViI Sympetalous Dicotyledons-Families and Genera............... 50

XViII Sympetalous Dicotyledons-Pyrolaceae, Monotropaceae, Ericaceae, Vacciniaceae, Primulaceae.............................

XiX Sympetalous Dicotyledons-Gentianaceae, Convolvdlaceae, Asclepiadaceae, Hydrophyllaceae, Boraginaceae, Polemoni-

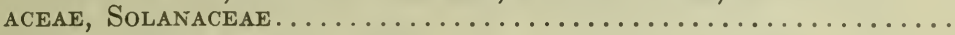

XX Sympetalous Dicotyledons-Labiatae, Verbenaceae, Orobanchaceae, LENTIBULARIACEAE, ScrophulariacEAE........................

XXI Sympetalous Dicotyledons-Caprifoliaceae, Rubiaceae, Cucurbitaceae, Campanulaceae， Lobeliaceae，Valerianaceae.........

XXII Sympetalous Dicotyledons-Compositae......................

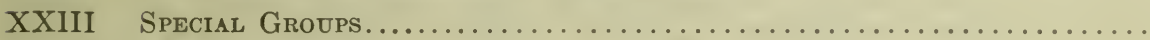

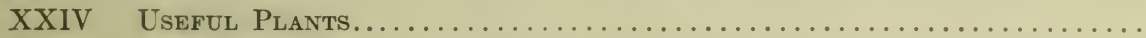

Index to Latin Names-Families, Genera and Species........... 88

Index to EngLish Names.............................. 93 
Digitized by the Internet Archive in 2013 


\section{A SHORT GUIDE TO CANADIAN GENERA OF SEED PLANTS}

\section{CHAPTER I}

\section{INTRODUCTION}

The present work includes all the genera of seed-plants that are indigenous in the Dominion of Canada. The Latin or scientific name of the genus is given in every case followed by the English name or names in brackets. In standard works the name, in abbreviated form, of the author who established or defined the genus is usually given in connection with the generic name but this practice is not usually followed in the more elementary treatises on botany such as the present. There is considerable difference of opinion among botanists as to the exact limits of a genus. Some authors regard Persicaria, Bistorta, Polygonella, etc., as distinct genera while others lump them together under the single genus Polygonum. Such synonyms, as they are called, will be found in the index of Latin names of genera and are indicated thus: "Persicaria=Polygonum", the symbol of equality in this case implying that the former genus is included under the latter.

In some cases the English and the Latin name of the species also are given when the species is easily recognizable either from its distribution in Canada or from some other character. Where only one species of a genus occurs in Canada the full double Latin name is given.

The more important families are also indicated with the genera included in each, except in those cases where the family includes a single genus, or a number of genera which have comparatively little in common, or whose classification still leaves room for doubt.

In order to determine the group or genus to which a particular plant belongs not only the leaves and flowers but also the ripe fruits are necessary and in some cases also the underground parts of the plant. As a general rule no difficulty need be experienced in ascertaining the main group to which a nlant belongs. The two principal groups of seed-plants are GYMNOSPERMS and ANGIOSPERMS which are easily distinguished. The ANGIOSPERMS are further divided into Monocotyledons and Dicotyledons, but in this case while the main features of each group are sufficiently distinct, exceptional forms occur. These are indicated in connection with the definitions of the two main groups. In the present work the DiсотYLEDons are further subdivided into three grouns. namely Apetalous, Choripetalous, and Sympetalous Dicotyledons, according as petals are absent, or free, or united. Here also exceptional forms occur and are separately indicated.

In order to find the name of the genus to which some plant, such as a species of Violet, belongs it will be necessary first of all to determine the main group in which it comes. As it has a closed ovary and five free petals it is obviously a Choripetalous Dicotylfonon. Hence to determine it we begin with ChoripetaLous DiCOTYLEDONs on page 30. Starting with grcup 1, as the Violet is a leafy plant it must be included under group 2. From group 2 we find that as the leaves are of the normal type we must refer it to group 4 which again leads on to group 
5 as the Violet is neither a shrub nor a tree. As the leaves are neither opposite nor whorled we pass on from group 5 to group 12 . The stipulate leaves of the Violet indicate that it belongs to group 13 and as the stamens are not united into a column we pass on to group 14 where the zygomorphic nature of the flower leads on to group 15. The spurred petal shows finally that the plant belongs to the family VIOLACEAE (page 48). As there are only two Canadian genera in this family the definitions show that the plant in question belongs to the genus Viola. In using the key as indicated above great care must be taken at each step to determine the characters concerned with strict accuracy otherwise the result will be disappointing. The characters given as distinguishing the various families and genera are applicable to Canadian plants only and do not necessarily hold good for plants in other parts of the world.

In this connection it may be advisable to refer to some plants whose classification is not easily determined, partly owing to the nature of the leaves or flowers. In some plants the venation of the leaves cannot be readily distinguished; in others the flowers are not typical for that group, or are rarely found.

In the family Lemnaceae which includes the two genera of aquatic plants known as Lemna and Wolffia there is no distinction between stem and leaf while in Wolffia roots also are absent. In the family Cactaceae the leaves are generally absent or rudimentary, their position being indicated by groups of spines. The genus Arceuthobium has very small leaves but can be readily recognized from its habit of growing as a parasite on coniferous trees.

There are a number of water plants in which the venation is obscure and the flowers very variable in type or rarely found. Of these the genera Elodea, Najas, Phyllospadix, some species of Potamogeton, Ruppia, and Zannichellia, agree with Monocotyledons in having simple leaves, while Ceratophyllum, Myriophyllum, and Podostemon have divided leaves and are Dicotylenons.

The carnivorous plants can be recognized by their peculiar leaves; they all belong to the group of Dicotyledons. Likewise the parasitic and saprophytic plants, which are devoid of green colouring matter are nearly all DiCOTYLEDONS.

Further reference to the identification of these and other groups will be found in Chapter XXIII.

At the end of each section dealing with a particular family or a group of miscellaneous genera, the distribution in Canada together with the number of species in each genus will be found. These genera are arranged in alphabetical order for convenience of reference. As opinions differ so greatly on the definition and limits of a species, the number of Canadian species occurring in each genus must be taken as an approximation only.

As regards the distribution in Canada of the various genera, the same arrangement of climatic areas has been adopted as in Department of Agriculture. Bulletin 58 entitled "A Survey of Canadian Plants in Relation to their Environment", Ottawa, 1926, where a definition of the boundaries of each area with accompanying map will be found. These six floral areas are Arctic, Northern, Eastern, Southern, Prairie and Western and are indicated for the sake of brevity by the first letter of each, namely, A.N.E.S.P.W. The boundaries of these six divisions are briefly as follows; the Arctic region lies beyond the northern limit of trees; the Northern or Transcontinental region is bounded on the north by the Arctic region and on the south by a line drawn from the western end of Anticosti island through the southern point of James bay, the northern end of lake Winnipeg, Lesser Slave lake, and the southerm boundary of Yukon Territory; the Eastern region includes the rest of Canada east of lake Winnipeg and Lake of the Woods except the region south of a line drawn from Kingston to Collingwood which constitutes the Southern region; the Prairie region extends from lake Winnipeg to the Rocky mountains while the Western region includes the Rockv mountains and the territory west of them and south of the Yukon boundary. 
It is perhaps needless to add that some knowledge of botany is necessary before attempting to find out the name of a plant but technical terms have hern sparingly used in the descriptions.

When the name of the genus has been determined a local "flora" must in most cases be consulted to determine the name of the species. The principal trees of the Dominion will be found in Morton and Lewis's Bulletin entitled "Native Trees of Canada," published by the Department of the Interior, Ottawa, 1917. Plants of the eastern and southern floral regions are described in Britton and Brown's "Illustrated Flora of the Northern United States and Canada," 3 vols., New York, 1913, and in "Gray's New Manual of Botany" 7th edition, by Robinson and Fernald, New York, 1908. "The Forest Trees of Ontario" by $\mathrm{J}$. H. White, Toronto, 1925 is well illustrated.

Prairie species are dealt with to some extent in Britton and Brown's work mentioned above, also in B. J. Hales' "Selected Western Flora," Toronto, 1915, P. A. Rydberg's "Flora of the Rocky Mountains and Adjacent Plains, New York, 1922, and W. C. McCalla's "Wild Flowers of Western Canada". Toronto, 1920.

The western region is covered by Brown and Schaeffer's "Alpine Flora of the Canadian Rocky Mountains" New York, 1907, J. K. Henry's "Flora of Southern British Columbia and Vancouver Island", Toronto, 1915, Piper and Beattie's "Flora of the Northwest Coast", Pullman, 1915, and Frye and Rigg's "Elementary Flora of the Northwest," New York, 1914. A useful work is also J. R. Anderson's "Trees and Shrubs, Food, Medicinal, and Poisonous Plants of British Columbia," Victoria, 1925, which contains a map and numerous illustrations. 


\section{PRINCIPAL SUBDIVISIONS OF SEED-PLANTS}

Woody plants with simple leaves; flowers unisexual; there is no ovary or stigma; seed naked or enclosed partially by scales=GYMNOSPERMS (Gymnospermae).

Herbaceous or woody plants with simple or divided leaves; flowers generally bisexual, though sometimes unisexual; an ovary and stigma are always present; seeds contained in a closed receptacle known as the fruit=ANGIOSPERMS (Angiospermae).

Exceptional Form: In Blue Cohosh (Caulophyllum thalictroides), which is an ANGIOSPERM, the developing seed bursts the ovary at an early stage so that the ripe seed appears to be naked.

\section{ANGIOSPERMS}

Mostly herbs, with the fibrovascular bundles of the stem scattered so that there is no distinct pith; leaves usually alternate, without stipules, simple, much longer than broad, with parallel veins; the parts of the flower are typically in threes; the seed has but one seed-leaf or cotyledon.=MoNocotyLEDons (Monocotyledones).

Herbs, shrubs or trees: fibrovascular bundles of the young stem typica!ly arranged in a circle with the pith in the centre; the leaves are net-veined; the parts of the flower are typically in fours or fives; the seed has two cotyledons.= Dicotyledons (Dicotyledones).

Exceptional Forms: Among Monocotylabons some species of Smilax have a woody stem; there is no distinction into stem and leaf in Lemna and Wolffia; opposite or whorled leaves occur in Elodea, Lilium, Medeola, Najas, Trillium, and Zannichellia; scales which somewhat resemble stipules occur within the leaf-sheath of Potamogeton and other aquatic plants while the base of the leaf of Smilax bears a pair of tendrils; divided leaves occur in Ariscema; netreined leaves are found in the family Araceae, Dioscorea, Medeola, Trillium, and Smilax; the parts of the flower are very variable in the family Araceae, Potamogeton, and allied genera.

Among Dicotyledons the arrangement of the fibrovascular bundles in the family Nymphaeaceae, some members of the family Ranunculaceae, Podophyllum, and some others resembles that of Monocotyledons; in the families Magnoliaceae, Berberidaceae, Lauraceae, Corema, Empetrum, and Floerkea, some of the floral whorls frequently consist of three members only.

\section{DiCOTYLEDONS}

Leaves usually simple; flowers naked or with a single perianth which is green or inconspicuous in colour, pollinated by wind.=APETALous Dicotyledons (Apetalae).

The perianth consists of two or more whorls, the petals being free and usually brightly coloured.=POLYPETALOUs DiCOTYLEDONs (Choripetalae).

The perianth consists of two whorls, the petals being united and usually brightly coloured; stamens in two, or more commonly in one whorl, epipetalous; 
ovary syncarpous, composed usually of two, rarely of 3-5 carpels. = SympeTalous Dicotyledons (Sympetalae).

Exceptional Forms: In the group of Apetalous Dictyledons compound leaves occur in Carya and Juglans and divided leaves in Ceratophyllum, Myriophyllum, Podostemon and Proserpinaca; the perianth is double in the pistillate flowers of Juglans, Myriophyllum, and some members of the family Polygonaceae; a coloured perianth is found in Abronia, Allionia, Asarum, Dirca, Phytolacca, and Polygonum; insect-pollinated flowers are found in Salix and water-pollinated flowers in Ceratophyllum.

Among the Polypetalous Dicotyledons the perianth is absent in Achlys triphylla, while it is single in Chrysosplenium, Corema, Penthorum, Rhamnus alnifolia, Sanguisorba, and some members of the family Ranunculaceae; the perianth is green or inconspicuous in Ceanothus, Corema, Elatine, Empetrum, Parthenocissus, Rhamnus, and Vitis; the petals are united at the base in the family Malvaceae and at the top in Vitis.

In the group of SympeTalous Dicotyledons the perianth is frequently single or absent in Fraxinus; petals are absent in Glaux and Synthyris; the petals are free in the family Pyrolaceae, Limonium, and Statice; the petals are not brightly coloured in Plantago and Littorella, while in Glaux the calyx is coloured; in the families Ericaceae, Pyrolaceae, and their allies, and also in those genera with free petals the stamens are scarcely epipetalous; the carpels are separate or nearly so in Apocynum and the family Asclepiadaceae. 


\section{CHAPTER III}

\section{GYMNOSPERMS-FAMILIES AND GENERA}

1. The stamens and ovules occur on separate plants, the stamens being in groups while the ovules occur singly; the ripe seed has a scarlet, fleshy, cup-shaped aril at its base $=$ Taxus.

The seeds are enclosed between the scales of the cone which becomes woody when ripe; the seed-coat is hard or leathery.=PINACEAE... . . . . . . . . . . 2

2. Leaves scale-like, opposite or whorled; scales of the cone opposite.......... 3

Leaves linear, alternate or on dwarf shoots; scales of the cone imbricated.. . . . . 4

3. Cone and scales oblong=Thuja.

Cone globose; scales peltate=Chamaecyparis.

Cone globose, berry-like, with concrescent scales=Juniperus.

4. Leaves borne in tufts at the summit of dwarf shoots. . . . . . . . . . . . . . 5

Leaves attached singly on long shoots.. . . . . . . . . . . . . . . . . . . . . . 6

5. Leaves numerous on each dwarf shoot, deciduous; cones maturing the first year=Larix. Leaves 2-5 on each dwarf shoot, persistent for several years; cones maturing the second year $=$ Pinus.

6. Branches rough, owing to persistent leaf-bases (sterigmata); cones pendulous.... 7 Branches smooth, without persistent leaf-bases................... . . 8

7. Leaves 4-sided, sessile on the persistent base=Picea .

Leaves flat, in 2 rows through twisting of the short petiole=Tsuga.

8. Leaves sessile with circular scars; cones erect, the scales falling away from the persistent axis =Abies.

Leaves petiolate, with oval scars; cones pendulous, with persistent scales; outer of each pair of scales 3-toothed=Pseudotsuga.

\section{Distribution of Genera}

Abies (Fir) NESPW. 4 sp. namely, Balsam Fir (A, balsamea) in East and North and 3 western species.

Chamaecyparis nootkatensis (Yellow Cypress) in the coast region of B.C.

Juniperus (Juniper) NESPW. 5 sp.

Larix (Larch) NESPW. 3 sp. of which the Tamarack (L. laricina) occurs in East and North while the other 2 are western.

Picea (Spruce) ANESPW. 5 sp.

Pinus (Pine) NESPW. $9 \mathrm{sp}$. Of the 5 -leaved species the White Pine ( $P$. Strobus) is the only one in the East; of the 3-leaved species the Pitch Pine ( $P$. rigida) is eastern while Western Yellow Pine (P. ponderosa) occurs in B.C.

- Pseudotsuga taxifolia (Douglas Fir) ranges from the Rocky mountains to the Pacific ocean. With the Western Cedar it shares the distinction of being one of the two largest trees in Canada.

Taxus (Yew) ESW. 2 sp. The Ground Hemlock (T. canadensis) is eastern while the Western Yew (T. brevifolia) is confined to the western region.

Thuja (Cedar) NESW. 2 sp. The White Cedar (T. occidentalis) occurs in the East and North, while the Western Cedar (T. plicata) is confined to B.C. and is one of the largest trees in Canada.

Tsuga (Hemlock) ESW. 3 sp. The Eastern Hemlock (T. canadensis) occurs east of the Great Lakes, while the other two species are western. 


\section{CHAPTER IV}

\section{MONOCOTYLEDONS-FAMILIES AND GENERA}

1. Free-floating water-plants without any evident distinction into stem and leaf.... 2

Plants with proper leaves.. . . . . . . . . . . . . . . . . . . . . . . 3

2. Plants provided with roots=Lemna.

Plants very minute, without roots=Wolffia.

3. Perianth single and then inconspicuous, or else absent................ 4

Perianth in two whorls, mostly inconspicuous.................... . . 12

Perianth in two whorls of 3 segments each, the inner being brightly coloured.. .. 18

Perianth in two whorls of 3 segments each, both whorls being brightly coloured. .. 24

4. Leaves mostly net-veined; flowers in a spadix, without bracts, but with a large spathe at the base which is often brightly coloured; fruit berry-like=ARACEAE (p. 12).

Marsh or land plants with grass-like leaves and usually bisexual flowers grouped in spikes or spikelets; the flower arises in the axil of one or more bracts, has 3 stamens and 2 or 3 stigmas.. . . . . . . . . . . . . . . . . . . . . . . . . . 5

Water or marsh plants with long leaves, dense inflorescences and unisexual flowers; the staminate flowers are borne uppermost on the axis; stigma usually single and

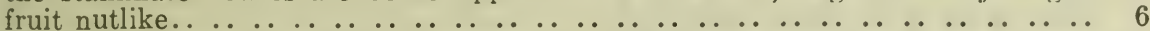

Water plants, generally entireiy submerged or with floating leaves; flowers in a spike or spadix, or solitary, frequently developing under the water.. . . . . . . . 7

5. Stem mostly solid and angular; leaves in 3 rows on the stem; leaf-sheath not split down one side; flowers borne in the axil of a single bract; the seed is free from the wall of the fruit=CYPERACEAE (p. 12).

Stem hollow and cylindrical; leaves in 2 rows on the stem; leaf-sheath usuaily split down one side; flowers in spikelets with usually two bracts (glumes) at the base of the spikelet and 2 others enclosing the flower; seed-coat united with the wall of the fruit, which is often enclosed between the 2 glumes=GRAMINEAE ( $p$. 14).

6. Flowers borne in a cylindrical unbranched inflorescence; fruit with long downy hairs attached $=$ Typha.

Inflorescence branched or unbranched, the flowers being borne in heads; fruit a fleshy nut=Sparganium.

7. Flowers bisexual, appearing above the surface of the water............ 8

Flowers, unisexual, developed below water. . . . . . . . . . . . . . . . . . . 99

8. Freshwater plants with flowers in a spike; stamens 4 , each with an outgrowth resernbling a perianth-segment; carpels 4 ; drupes sessile $=$ Potamogeton.

Plants occurring in brackish water with flowers in a spadix; stamens 2 ; carpels 4; drupes stalked = Ruppia.

9. Leaves opposite or whorled.. . . . . . . . . . . . . . . . . . . . . . . . 10

Marine plants with alternate, ribbon-shaped leaves and flowers in a flat spadix.. 11

Leaves terete, fleshy, forming a rosette; flowers in a spike=Lilaea.

10. Leaves spiny-toothed; pistillate flowers solitary $=$ Najus.

Leaves capillary, smooth: pistillate flowers in groups of $2-5$ in a cup-shaped involucre $=$ Zannichellia.

11. Plants monoecious, with two longitudinal rows of alternating stamens and carpels; fruit rounded at the base=Zostera.

Plants dioecious, the staminate flowers occuring in two longitudinal rows on the spadix, the pistillate being similarly grouped; fruit cordate at the base=Phy lospadix.

12. Some or all of the flowers unisexual....................... 13

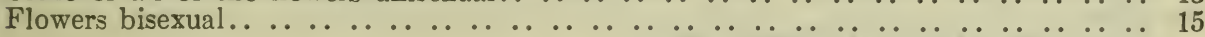

13. Land-plants with twining stems, cordate, net-veined leaves, and inferior ovary=Dioscorea.

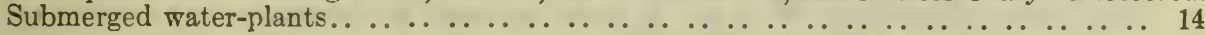


14. Leaves awl-shaped, forming a rosette; flowers in heads at the top of the scape= Eriocaulon.

Stems branched; leaves opposite or whorled, 1-nerved=Elodea.

Plants stoloniferous, with ribbon-shaped, 5-nerved leaves; pistillate flower on a long stalk=Vallisneria .

15. Flowers grouped in a raceme......................... 16

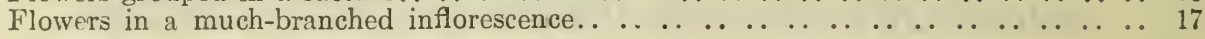

16. Leaves all basal with the flowers on a bractless scape=Triglochin.

Stem leafy, with bracts beneath the flowers=Scheuchzeria.

17. Mostly marsh plants with narrow leaves and open leal-sheath; capsule many-seeded= Juncus.

Leaves usually flat and hairy, with closed leaf-sheath; capsule 1-celled, 3-seeded=Luzula.

18. Aquatic plants.. . . . . . . . . . . . . . . . . . . . . . . . . . 19

Land plants with 3 broad, whorled, net-veined leaves; fruit a berry=Trillium.

Land plants with narrow, basal or alternate leaves; fruit a capsule=Calochortus.

19. Ovary syncarpous............................... 20

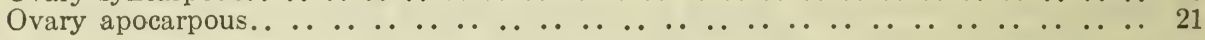

20. Plants floating, stoloniferous, with cordate leaves, and many-celled ovary=Limnobium. Plants with basal, narrow leaves and flowers in a head at the top of the scapee; ovary 1-celled=X yris.

21. Flowers bisexual. . . . . . . . . . . . . . . . . . . . . . . . . 22

Some or all of the flowers unisexual. ... . . . . . . . . . . . . . . . . . . . . . 23

22. Carpels in a single whorl=Alisma.

Carpels in several series forming a head=Echinodorus.

23. Lower flowers bisexual, the upper staminate; stamens 9-15=Lophotocarpus.

Lower flowers pistillate, the upper staminate; stamens numerous=Sagittaria.

24. Ovary superior.. . . . . . . . . . . . . . . . . . . . . . . 25

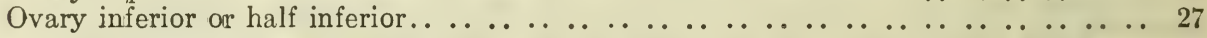

25. Aquatic plants with 6 stamens or $3 \ldots \ldots \ldots \ldots \ldots \ldots \ldots \ldots \ldots \ldots \ldots \ldots \ldots . \ldots 26$ Mostly land-plants with actinomorphic flowers and 6 stamens=LILIACEAE (p. 20).

26. One-leaved plants, with 2-lipped blue perianth and 6 stamens; fruit 1-seeded, indehiscent= Pontederia.

Perianth pale-yellow; stamens 3 ; fruit a many-seeded capsule=Heteranthera.

27. Stamens 6=AMARYLLIDACEAE (p. 22).

Leaves in 2 rows; stamens $3=$ IRIDACEAE (p. 22).

Corolla zygomorphic, one of the petals (labellum) being different from the others; stamens sometimes 2 , usually 1 ; fruit a 1 -celled capsule with very minute seeds= ORCHIDACEAE (p. 22).

\section{Distribution of Genera}

Alisma Plantago-aquatica (Water-plantain) NESW:

Calochortus (See page 21).

Dioscorea villosa (Wild Yam-root) S.

Echinodorus parvulus (Dwari Water-plantain) S.

Elodea (Water-weed) ESP. 2 sp.

Eriocaulon septangulare (Pipewort) ES.

Heteranthera dubia (Water-stargrass) ES.

Juncus (Rush) ANESPW. 46 sp.

Lemna (Duckweed) NESPW. 3 sp. Greater Duckweed (L. polyrrhiza) has several roots on each frond.

Lilaea subulata (Flowering Quillwort) W:

Limnobium Spongia (Frog's Bit) S. It has white flowers.

Lophotocarpus spongiosus (Sea Arrow-head) E. It occurs in brackish marshes along

the coast.

Luzula (Wood-rush) ANESPW. $10 \mathrm{sp.}$

Najas flexilis (Water-nymph) NESW.

Phyllospadix (Surf-grass) W. 2 sp. It grows on rocks in the sea.

Pontederia cordata (Pickerel-weed) ES. 
Potamogeton (Yondweed) NESPW. $27 \mathrm{sp}$. Some species have broad floating leaves, while in others the leaves are submerged and linear or threadlike. water.

Ruppia (Ditch-grass; Tassel-pondweed) EPW. 2 sp. Both species occur in brackish

Sagittaria (Arrow-head) NESPW. 4 sp.

Scheuchzeria palustris (Creeping Arrow-grass) NESW.

Sparganium (Bur-reed) ANESPW. $10 \mathrm{sp}$.

Triglochin (Arrow-grass) ANESPW. 2 sp. Marsh Arrow-grass (T'. palustris) has 3 carpels. whereas Sea Arrow-grass (T. maritima) has 6 carpels.

Trillium (See page 22).

Typha (Cat-tail; Reed-mace) NESPW. 2 sp.

Vallisneria spiralis (Eel-grass; Wild Celery) ES.

Wolffia (Rootless Duckweed) S. 2 sp.

Xyris (Yellow-eyed grass) ES. 2 sp. The flowers are yellow.

Zannichellin palustris (Horned Pondweed) ESPW.

Zostera marina (Sea Eel-grass, Grass-wrack) ANEW. It occurs chiefly in muddy estuaries. 


\section{CHAPTER V}

\section{MONOCOTYLEDONS-ARACEAE AND CYPERACEAE}

\section{ARACEAE}

1. Flowers without a perianth; some or all of the flowers unisexual........... 2 Perianth present; flowers bisexual.. . . . . . . . . . . . . . . . . . . . 4

2. Leaves divided; flowers present at the base of the spadix only=Arisaema. Leaves simple; flowers covering the whole spadix.................. . . . . . 3

3. Leaves sagittate; spathe narrow, convolute, green; all the flowers unisexual=Peltandra. Leaves broadly cordate; spathe broad, white; uppermost flowers sometimes staminate $=$ Calla.

4. Leaves linear, aromatic; spathe leaflike, appearing as a prolongation of the scape with the spadix laterally attached=Acorus.

Leaves broad, fetid; spadix borne at the top of the scape.. . . . . . . . . . . 5

5. Leaves cordate at the base; scape scarcely rising above ground-level; berries sunk in the fleshy axis of the spadix, becoming united with the fleshy perianth=Symplocarpus.

Leaves narrowed at the base into the petiole; scape elongated, with the stalk of the spadix exserted beyond the yellow spathe $=$ Lysichiton.

\section{Distribution of Genera}

Acorus Calamus (Sweet Flag) ES. It grows in swampy situations.

Arisaema (Indian Turnip) ES. $2 \mathrm{sp.} \mathrm{Jack-in-the-pulpit} \mathrm{(A.} \mathrm{triphyllum)} \mathrm{with} 3$ leaflets occurs in the eastern and southern regions, while Dragon-root ( $A$. Dracontium) with 7 or more leaflets is confined to southern Ontario. Both occur in moist soil.

Calla palustris (Water Arum) NESPW. It occurs in boggy situations.

Lysichiton camtschatcensis (Western Skunk Cabbage) W. It occurs in swampy situations.

Peltandra virginica (Arrow-arum) S. It occurs in shallow water.

Symplocarpus foetidus (Eastern Skunk Cabbage) ES. It occurs in swamps.

\section{CYPERACEAE}

1. Flowers all unisexual, without a perianth.................... 2

Some or all of the flowers bisexual.. . . . . . . . . . . . . . . . . 4

2. Stamens 3 ; achene enclosed or partially enclosed by a bract. . . . . . . . . . 3 Pistillate spikelet 1-flowered; stamens 1-3; achene bony in texture, without a bract surrounding it $=$ Scleria.

3. Spikelet 1-flowered, or 2-flowered, one being staminate and the other pistillate; stigmas 3 ; achene partly enclosed by a bract $=$ Kobresia.

Spikelet several-flowered; stigmas 2-3; achene completely enclosed by a flask-like bract $($ perigynium $)=$ Carex.

4. No perianth present............................. . . . . 5

Perianth present, composed of bristles. . . . . . . . . . . . . . . . . 8

5. There is an involucre of several leaves at the base of the inflorescence; flowers in 2 rows in each spikelet $=$ Cyperus.

Spikelets terete, with the flowers spirally arranged.. . . . . . . . . . . . . . . 6

6. Lower scales of the spikelet empty; stamens 2 ; styles $3=$ Cladium.

Inflorescence subtended by an involucre of one or more leaves; all the scales of the

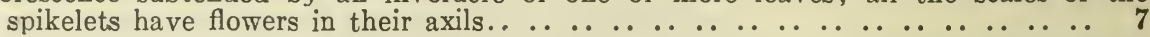

7. Annual tufted plants with filiform leaves; spikelets solitary or in heads; there is a single hyaline inner scale between the flower and the axis of the spikelet; stamen single; styles $2=$ Hemicarpha.

Spikelets umbellately arranged; stamens $1-3$; styles $2-3$; achene striate or reticulate= Fimbristylis. 
S. Stem terete and hollow, leafy to the top, the lower leaves being reduced to sheaths. Flowers in 2 rows in long narrow spikelets which break up into 1-seeded joints when ripe; bristles of the perianth barbed; styles $2=$ Dulichium.

Flowers spirally arranged in the spikelet.................... . . . 9

9. Perianth bristles much exserted from the scales as the fruit ripens; styles $3=$ Eriophorum. Perianth bristles not becoming elongated, barbed; styles 2-3.. . . . . . . . . . 10

10. Leaves mostly reduced to sheaths; spikelets solitary and terminal; bristles 1-12; stamens 2-3; the base of the style forms a persistent tubercle on the tip of the fruit $=$ Helcocharis.

Stem leafy; spikelets clustered, few-flowered, the lower scales empty and the upper flowers sometimes staminate; scales of the spikelet of ten mucronate; stamens 3 ; styles 2 ; achene lenticular, capped by the persistent base of the style as a small tubercle = Rhynchospora .

Leaves well developed or reduced to sheaths; spikelets clustered or solitary; involucre of one to several leaves, or absent; perianth bristles usually 1-6; stamens 2-3; style usually deciduous but sometimes forming a subulate tip to the lenticular or triangular achene $=$ Scirpus.

\section{Distribution of Genera}

Carex (Bottle-sedge) ANESPW. $277 \mathrm{sp}$. In some species the inflorescence consists of a single spikelet while in others it is branched and composed of several spikelets; both staminate and pistillate flowers may occur in the same spikelet or they may be confined to separate spikelets, in which case the staminate spikelets occur nearest the top.

Cladium mariscoides (Twig-rush) ES.

Cyperus (Cypress-sedge; Nut-grass) NESPW. $12 \mathrm{sp.}$

Dulichium arundinaceum (Bamboo-sedge) ESW.

Eriophorum (Cotton-grass) ANESPW. $10 \mathrm{sp.}$

Fimbristylis (Rib-sedge) S. $4 \mathrm{sp}$.

Heleocharis (Spike-rush) NESPW. $13 \mathrm{sp}$.

Hemicarpha (Scale-sedge) SW. 2 sp.

Kobresia (Wrapper-sedge) ANW. 2 sp.

Rhynchospora (Beak-rush) NESW. 4 sp.

Scirpus (Club-rush; Bulrush) ANESPW. $24 \mathrm{sp.}$

Scleria (Nut-rush) S. 2 sp. 


\section{CHAPTER VI}

\section{MONOCOTYLEDONS-GRAMINEAE}

The general characters of this large family are as follows: Mostly perennial herbs with cylindrical stems; nodes well marked, internodes hollow. Leaves in 2 rows on the stem, consisting of a sheath and blade; the edges of the sheath overlap and there is a small hyaline membrane or tuft of hairs at the junction of the sheath and blade known as the ligule. The inflorescence may have one of three forms, namely, a compound spike, an open or contracted panicle, or a more or less cylindrical inflorescence in which the spikelets are crowded together on short stalks. The unit of the inflorescence in each case is the spikelet. It consists typically of an axis known as the "rachilla" bearing a series of flowers in 2 rows along it with a pair of bracts at the base of the spikelet known as the "empty glumes." Each flower is likewise enclosed between two bracts of which the lower is known as the "flowering glume"; it frequently bears a bristle-like outgrowth or prolongation of the midrib known as the "awn." The upper bract at the base of the flower is 2-nerved and is known as the "pale." Inside these two bracts are 2 small hyaline, succulent scales known as the "lodicules" which appear to represent a perianth. The grass flower is usually bisexual with 3 stamens and a single carpel. The stamens have long filaments, versatile anthers and powdery pollen, while the ovary bears 2 feathery stigmas. In some grasses the flowers in each spikelet may be reduced to 2 in number while in others there is only 1 . The fruit is a caryopsis which is usually enclosed when ripe by the flowering giume and pale becoming more or less adherent to it.

The habitat of grasses varies greatly some being found in woods while others prefer the open country. Among the aquatic or marsh species are Beckmannia, Catabrosa, Panicularia, Phalaris, Phragmites, Spartina sp. and Zizania. Characteristic of sandy habitats are Ammophila, Calamovilfa, Cenchrus, Elymus sp., and Triplasis, while Distichlis, Puccinellia and Spartina sp. show a partiality to saline soil.

There are some exceptions to the general characters of grasses as given above. Among Canadian species annuals occur in Aristida dichotoma, Beckmannia erucaeformis, Cenchrus, Deschampsia danthonioides, Eragrostis, Festuca sp., Munroa squarrosa, Panicum sp., Poa sp., Sporobolus vaginaeflorus and Zizania aquatica.

The stem is solid in Andropogon and Sorghastrum. A closed leaf-sheath occurs in species of Bromus, Danthonia, Festuca, Malica, Panicularia and Poa. The inflorescence is reduced to a single spikelet in Danthonia unispicata. Empty glumes are absent in Leersia and in the pistillate flowers of Zizania, while the staminate flowers of Zizania have only 1. In Eragrostis the pale is persistent on the rachilla while in Alopecurus, some species of Agrostis, and the staminate flowers of Zizania the pale is absent.

Unisexual flowers on the same plant occur in Andropogon, Buchloë, Hierochloë, Panicum, Phragmites, Sorghastrum and Zizania, while the unisexual flowers are on separate plants in Distichlis, Eragrostis hypnoides and Poa fendleriana.

A single stamen occurs in the flowers of Cinna; in Brachyclytrum and the terminal flower of the spikelet of Hierochloë there are 2 stamens, while in Zizania the flower has 6 stamens.

In Sporobolus the seed is free from the pericarp.

1. Inflorescence branched, the spikelets occurring on the branches.. . . . . . . . . 2

Inflorescence unbranched, that is, the sessile spikelets occur in groups of $1-3$ along opposite sides of a central axis or rachis which terminates the leafy stem.. 57

2. Annual plants with spikelets grouped in racemes, each spikelet being enclosed in a spiny involucre of sterile branchlets which falls off with it=Cenchrus.

Spikelets without a spiny involucre.. $\ldots \ldots \ldots \ldots \ldots$

3. Stern solid; spikelets grouped in pairs on the hairy rachis, one spikelet being sessile and the other stalked; the spikelets are jointed below the glumes; the sessile spikelet bears a single bisexual flower with 4 glumes and a pale while the stalked spikelet contains a single staminate or rudimentary flower; flowering glume awned. . . . . . . . . . . . . . . . . . . . . . . . . . . . . . . . . . . . . . 4

Stem usually hollow and spikelets not grouped in pairs. . . . . . . . . . . . . . .

4. Spikelets in compound spikes or racemes which are attached to the main axis= Andropogon.

Spikelets in short racemes which are grouped together in the form of a panicle= Sorghastrum. 
5. The ultimate branches of the inflorescene are spikes or racemes on which the spike-

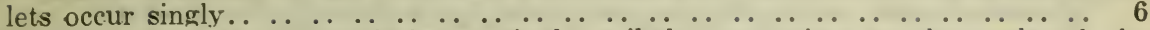

Inflorescence branching irregularly, a single spikelet occurring at the ends of the ultimate branches; the inflorescence may take the form of an open or contracted panicle, an apparent spike, or a cylindrical mass of closely arranged spikelets. 12

6. Perennial stoloniferous plants with unisexual flowers; staminate spikelets 2-flowered. sessile in 2 rows on one side of the rachis; pistillate spikelets 1 -flowered, in groups of 3-5 in a short spike, the common peduncle included in the sheath of the upper leaves $=$ Buchlö̈.

Flowers bisexual..

7. Marsh grasses with rough leaf-blades; spikelets flattened, 1-flowered, nearly sessile on one side of the rachis, grouped in panicles; empty glumes absent; flowering glume boat-shaped, hairy; stamens 1-6=Leersia.

Empty glumes present.. . . . . . . . . . . . . . . . . . . . . . . 8

S. Spikelets grouped along one side of the rachis, 1-flowered or with only 1 perfect

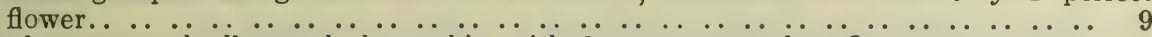

Spikelets grouped all round the rachis, with 2 or more perfect flowers.. . . . . . 11

9. One or more rudimentary flowers occur in each spikelet besides the perfect one; empty glumes unequal; flowering glume with 3 awns=Bouteloua.

Spikelets 1-flowered.. . . . . . . . . . . . . . . . . . . . . . . . . . . . . . . . . . . . . . 10

10. Plants tufted, perennial; spikelets appressed and distant on the rachis which is triangular and becomes spiral in fruit; empty glumes acuminate=Schedonnardus.

Annual plants; spikelets subcircular, compressed, articulated below the glumes; empty glumes boat-shaped, equal=Beckmannia.

Perennial plants with rhizomes; spikelets flattened, imbricated on one side of the rachis, articulated below the glumes; empty glumes unequal, acuminate or awned =Spartina.

11. Low annual plants branching extensively, with fascicled flat leaves ending in subulate points; spikelets in clusters of $2-3$, nearly sessile in the axils of the leaves, 2-4flowered = Munroa.

Spikelets in a loose raceme, 5-14-flowered; empty glumes unequal, with lacerate tips= Pleuropogon.

12. Spikelets on very short stalks, densely crowded together in a cylindrical or spike-like

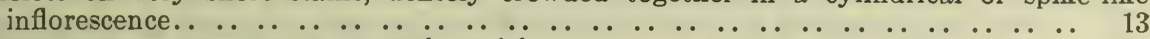

Inflorescence an open or contracted panicle..

13. Spikelets 1 -flowered .. . . . . . . . . . . . . . . . . . . . . . . . 14

Inflorescence spike-like, with $\ddot{2}$ or more flowers, of which some may be rudimentary 17

14. Inflorescence cylindrical; spikelets compressed. . . . . . . . . . . . . . . . 15

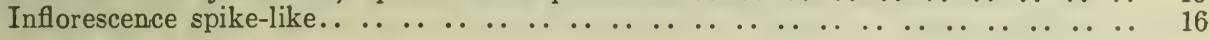

15. Spikelets jointed below the glumes; empty glumes ciliate on the keel; flowering glume awned; pale absent=Alopecurus.

Spikelets jointed above the glumes; empty glumes with short awns; flowering glume truncate $=$ Phleum.

16. Dwarf tufted perennials; empty glumes unequal; rachilla not prolonged; usually only 1 stamen present=Phippsia.

Perennial plants with tough scaly rhizomes and involute leaves; spikelets compressed; empty glumes equal; rachilla prolonged beyond the palea and hairy=Ammophila.

17. Perennial plants with rhizomes; some of the flowers rudimentary or unisexual.. 18

Tufted perennials with narrow leaves and 2 or more perfect flowers in the spikelet;

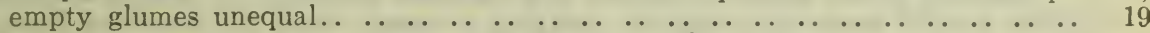

Tufted perennials with 3 or more perfect flowers in the spikelet; empty glumes broad, papery, equal, longer than the rest of the spikelet; flowering glume deciduous, bifid, with a twisted awn arising at the tip=Danthonia intermedia.

18. Plants with broad leaves and compressed spikelets with 1 perfect and 2 rudimentary flowers, the flowering glume in the latter being subulate and hairy; empty glumes equal, boat-shaped, longer than the flowering glume of the perfect flower which becomes shining in fruit=Phalaris.

Dioecious plants with scaly rhizomes occurring on saline soil; spikelets 6-many-flowered; empty glumes unequal, shorter than the flowering ones=Distichlis. 
19. Spikelet compressed; flowering glume not awned=Kocleria

Flowering glume acute, with the awn about the middle=Avena Hookeri.

Flowering glume awned, and with a tuft of hairs at the base, the awn arising below the bifid apex $=$ Trisetum spicatum.

20. Spikelets 1 -flowered.. . . . . . . . . . . . . . . . . . . . . . . . . . . . . . . . . 21

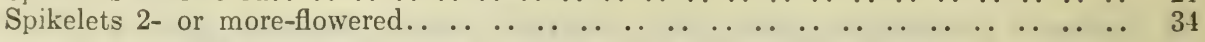

21. Awns absent.. . . . . . . . . . . . . . . . . . . . . . . . . . . . . . . . 22

Awns present. . . . . . . . . . . . . . . . . . . . . . . . . . . . 26

22. Plants with rhizomes and leaves involute at the tip; there is a tuft of hairs at the base of the flowering glume=Calamovilfa.

Flowering glume without a tuft of hairs . . . . . . . . . . . . . . . . . . . 23

23. Empty glumes equal or nearly so, as long as or longer than the obtuse flowering

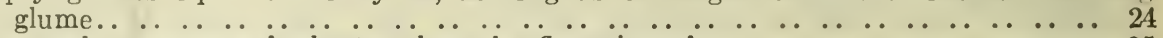

Empty glumes unequal, shorter than the flowering glume.. ........... . . . 25

24. Empty glumes acute, keeled; pale small or obsolete=Agrostis sp.

Empty glumes obtuse; flowering glume becoming at maturity hardened, smooth, and shining $=$ Milium.

25. Panicle contracted; flowering glume obtuse; fruit enclosed by flowering glume and pale $=$ Arctagrostis.

Panicle contracted or open; flowering glume 1-nerved; fruit at an early stage becoming free from the flowering glume and pale; seed free from the pericarp=Sporobolus.

26. Rachilla prolonged beyond the pale..................... 27

Rachilla not prolonged beyond the pale.. . . . . . . . . . . . . . . . . . . 29

27. Rachilla hairy and flowering glume hairy at the base; empty glumes equal, longer than the flowering glume=Calamagrostis.

Rachilla and flowering glume not hairy.. . . . . . . . . . . . . . . . . . . . 28

28. Rhizomes short and knotty; empty glumes unequal, shorter than the flowering glume which has a long awn; stamens $2=$ Brachyelytrum.

Spikelet articulated below the empty glumes; awn of the flowering glume minute; stamen $1=$ Cinna.

29. Aquatic plants with unisexual flowers, the pistillate flowers being situated above the staminate; stamens 6 ; the staminate flower has only 1 empty glume and no pale; the pistillate flower has no empty glumes, but has a flowering glume with long awn and a pale =Zizania.

Land plants with bisexual flowers.. . . . . . . . . . . . . . . . . .

30. Plants with narrow, often convolute leaves; empty glumes narrow and pointed; flowering glumes narrow, convolute, indurated, with minute hairs at the base, and a trifid awn $=$ Aristida .

Flowering glume with single awn. . . . . . . . . . . . . . . . . . . . . . 31

31. Leaves convolute; empty glumes long, narrow, and pointed; flowering glume with a tuft of hairs at the base, convolute, indurated, enclosing the pale and terminating in a long, bent and twisted awn=Stipa.

Awn not twisted.. . . . . . . . . . . . . . . . . . . . . . . . . . . . . . . . . . 32

32. Tufted perennials; spikelets broad; empty glumes about equal, as long as the flowering glume which is convolute and indurated; awn short and deciduous=Oryzopsis.

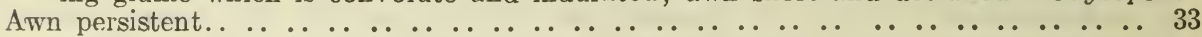

33. Scaly rhizomes generally present; empty glumes sometimes unequal, shorter than the flowering glume which is pointed and minutely hairy at the base.=Muhlenbergia.

Empty glumes equal or nearly so, equalling or longer than the flowering glume which is obtuse; pale usually small or obsolete.=Agrostis $s p$.

34. Awns absent.................................. . . . . . . . . .

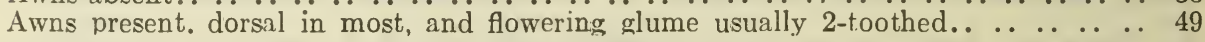

35. There is a tuft of hairs at the base of the flowering glume or the rachilla is hairy.. 36

No obvious tuft of hairs present on flowering glume or rachilla......... . 40

36. Rachilla hairy ... . . . . . . . . . . . . . . . . . . . . . . 37

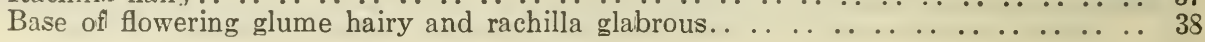


37. Tall water or marsh plants with broad leaf-blades; first flower of the spikelet sterile or staminate.=Phragmites.

All the flowers of the spikelet are bisexual=Trisetum melicoides.

35. Empty glumes rounded at the base. . . . . . . . . . . . . . . . . . . . . . 39

Leaves boat-shaped at the tip; spikelets 2- or more-flowered; empty glumes keeled, shorter than the flowering glumes.=Poa.

39. Low grasses with empty glumes enclosing the rest of the spikelet, the lower one being one-nerved, the upper 3-nerved.=Dupontia.

Tall aquatic or marsh grasses with the enipty glumes shorter than the rest of the spikelet; lower empty glume 3 -nerved, the upper 5-nerved.=Fluminia.

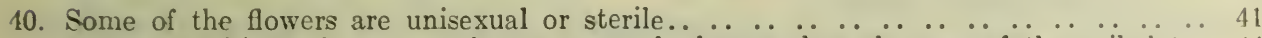

Flowers all bisexual; empty glumes unequal, shorter than the rest of the spikelet.. 44

41. Plants dioecious=Eragrostis hypnoides.

Some of the flowers are bisexual. . . . . . . . . . . . . . . . . . . .

42. Plants with closed leaf-sheaths; spikelets 2-several-flowered, the lower flowers bisexual, the upper sterile and with the glumes convolute round each other; empty glumes unequal, with scarious margins, 3-5-nerved.=Melica $s p$.

Lower flowers staminate or sterile, upper bisexual. . . . . . . . . . . . . . .

43. Spikelet 2-flowered, the lower flower being sterile or staminate, the upper bisexua, empty glumes very unequal, the first often minute; fertile flowering glume shining, with inrolled edges, enclosing the pale.=Panicum.

Aromatic plants with 3-flowered spikelets; empty glumes sub-equal, longer than the flowering glumes; the two lower flowers are staminate and have 3 stamens, while the terminal flower is bisexual and has 2 stamens.=Hierochlö̈ $s p$.

41. Aquatic creeping plants, with the branches of the panicle in regular whorls; spikelets 2 -flowered; flowering glume erose-truncate.=Catabrosa.

Branches of the panicle irregular; spikelets with 2 or more flowers.. .. . . . . . . 45

45. Tufted plants with somewhat contracted panicle; spikelets jointed below the empty glumes, 2-3-flowered, the rachilla extending beyond the upper floret; upper empty glume broadly obovate. $=$ Sphenopholis.

Spikelets not jointed below the empty glumes, usually several-flowered.. .. . . . . 46

46. Empty glumes and flowering glumes keeied. . . . . . . . . . . . . . . . 47

Flowering glumes rounded, 5 -9-nerved. . . . . . . . . . . . . . . . . . . . . . . . . 48

47. Flowering glume 3 -nerved, deciduous; pale persistent on the rachilla; stamens $2-3=$ Eragrostis.

Flowering glume 5-nerved, persistent; stamens $3 .=P o a s p$.

48. Usually tall plants of woods or freshwater marshes; nerves of the flowering glume prominent=Panicularia.

Low plants growing in saline soil; nerves of the flowering glume obscure $=$ Puccinellia.

49. Rachilla prolonged beyond the last flower and usually hairy . . . . . . . . . . . 50

Rachilla not prolonged beyond the last flower. . . . . . . . . . . . . . . . . . 52

50. Tufted plants with 3-many-flowered spikelets; empty glumes, broad and papery, longer than the rest of the spikelet; flowering glume deciduous, bifid, with a twisteds awn arising at the tip=Danthonia.

Spikelets 2-5-flowered; awn of flowering glume dorsal, inserted below the tip.. .. 51

51. Spikelet 2-flowered; empty glumes about equal; flowering glume convex, truncate and toothed at the tip, with the awn arising at, or below the middle=Deschampsia.

Spikelet 2-5-flowered; empty glumes somewhat unequal; flowering glume deciduous, keeled, bifid, with the awn arising above the middle=Trisetum.

52. There are cleistogamous narrow panicles in the axils of the leaves, those in the lower sheaths consisting of a single flower; the stem breaks at the internodes, the ripe seed remaining attached to the internode; other spikelets 2-6-flowered; empty glumes keeled, nearly equal; internodes of rachilla very long; flowering glume rounded at at the base, 3-nerved, bilobed; pale 2-keeled, the keels ciliate on the upper half=Triplasis.

Spikelets all freely exposed; flowering glumes with 5 or more nerves........ 53 
53. Some of the flowers are unisexual or sterile... . . . . . . . . . . . . . . 54

Flowers all bisexual. . . . . . . . . . . . . . . . . . . . . . . . . . . . . . . . . . 55

54. Lower flowers bisexual, the upper stcrile and with the glumes convolute round each other=Melica $s p$. (See no. 42).

The two lower flowers are staminate, while the upper flower is bisexual=Hierochloe sp. (See no. 43).

55. Flowering glume bifid at the tip........................ 56 Empty glumes keeled; Howering glume not bifid at the tip, with terminal awn= Festuca.

56. Empty glumes about equal; rachilla bearded; flowering glume indurated; awn dorsal, bent and twisted=Avena.

Plants with closed leaf-sheaths; empty glumes unequal; awn springing between the teeth of the flowering glume $=$ Bromus.

57. There is a single spikelet at each notch of the rachis; each spikelet is several-flowered= Agropyron.

There are 2 or more spikelets at each notch of rachis.. . . . . . . . . . . . 58

58. Three spikelets occur at each notch; each spikelet contains a single flower but those in the lateral stalked spikelets are usually rudimentary=Hordeum.

There are 2-3 spikelets at each notch; each spikelet contains 2 or more flowers.. . 59

59. Spikelets loosely arranged on the spike and spreading horizontally; empty glumes wanting or reduced to short bristles; flowering glume tapering into a long awn=Asperella. Spikelets usually crowded and not spreading, empty glumes nearly as long as the flowering glumes and often placed in front of the spikelet; flowering glume usually awned $=$ Elymus.

\section{Distribution of Genera}

Agropyron (Wheat-grass) ANESPW. 16 sp.

Agrostis (Bent-grass) NESPW. 21 sp.

Alopecurus (Foxtail) ANESPW. 6 sp.

Ammophila arenaria (Marram-grass) ES.

Andropogon (Beard-grass) ESP. 2 sp.

Arctagrostis latifolia (Arctic Bent-grass) ANW.

Aristida (Needle-grass) SPW. 3 sp.

Asperella Hystrix (Bottle-brush grass) ESP.

Avena (Oat) ESPW. 2 sp.

Beckmannia erucaeformis (Slough-grass) NEPW.

Bouteloua (Grama-grass) EPW. 3 sp.

Brachyelytrum erectum (Bearded Short-husk) ES.

Bromus (Brome-grass) ANESPW. $16 \mathrm{sp.}$

Buchloë dactyloides (Buffalo-grass) P.

Calamagrostis (Reed-grass) ANESPW. $24 \mathrm{sp}$.

Calamovilfa longifolia (Awnless Sand-grass) NESPW.

Catabrosa aquatica (Water whorl-grass) NEW.

Cenchrus pauciflorus (Sand-bur) S.

Cinna (Wood reed-grass; Indian reed) ESW. $2 \mathrm{sp.}$

Danthonia (Oat-grass) ESPW. 7 sp.

Deschampsia (Hair-grass) ANESPW. 7 sp.

Distichlis (Salt-grass; Alkali-grass) EPW. $2 \mathrm{sp.}$

Dupontia Fischeri (Arctic pappus-grass) A.

Elymus (Lyme-grass) ANESPW. 21 sp.

Eragrostis (Love-grass) SPW. 2 sp.

Festuca (Fescue-grass) ANESPW: 20 sp.

Fluminia festucacea (Prickle-fescue) PW.

Hierochloë (Holy Grass) ANESPW. 3 sp.

Hordeum (Barley) ANESPW. 4 sp.

Koeleria cristata (Crested hair-grass) ESPW.

Leersia (Cut-grass; White grass) ESP. 2 sp.

Melica (Melic-grass) W. $7 \mathrm{sp.}$

Milium effusum (Millet-grass) ES.

Muhlenbergia (Satin-grass) NESPW. $10 \mathrm{sp}$.

Munroa squarrosa (False buffalo-grass) P.

Oryzopsis (Mountain-rice; Indian millet) NESPW. 6 sp.

Panicularia (Manna-grass) ANESPW. 19 sp. 
Panicum (Panic-grass; Witch-grass) ESPW. $34 \mathrm{sp.}$

Phalaris arundinacea (Reed Canary-grass) ESW.

Phippsia algida (Dwarf grass) AW.

Phleum (Timothy) NESPIV. 2 sp.

Phragmites communis (Reed) FSPW.

Pleuropogon (Whisker-grass) AW. 2 sp.

Poa (Meadow-grass; Spear-grass) ANESPW. 51 sp.

Puccinellia (Salt-meadow grass) ANESPW. $6 \mathrm{sp}$.

Schedonnardus paniculatus (Prairie tumble-grass) P.

Sorghastrum mutans (Indian grass) ESP.

Spartina (Marsh-grass; Cord-grass) ESPW. $5 \mathrm{sp.}$

Sphenopholis (Wedge-grass) ESPW. 3 sp.

Sporobolus (Dropseed) NESPW. 8 sp.

Stipa (Feather-grass; Porcupine-grass) NEPW. 8 sp.

Triplasis purpurea (Awned Sand-grass) S.

Trisetum (False oat) ANESW. 7 sp.

Zizania aquatica (Wild rice) ES. 


\section{CHAPTER VII}

\section{MONOCOTYLEDONS-LILIACEAE, AMARYLLIDACEAE, IRIDACEAE, ORCHIDACEAE}

\section{LILIACEAE}

The general characters of this family are as follows: Perennial herbs with bulbs, corms, or rhizomes. The flowers are grouped in racemes or umbellate cymes or may be solitary. They are generally bisexual. The perianth consists of two whorls of 3 segments each, brightly coloured. Stamens 6 , in two whorls. Ovary superior, consisting of 3 united carpels, trilocular, with axile placentation and numerous ovules. Fruit a capsule or berry.

Several exceptional forms occur. Some species of Smilax are woody. Net-veined leaves are found in Medeola, Smilax, and Trillium. Unisexual flowers occur in Chamaelirium, Smilax, and Zygadenus sp. The outer perianth-whorl is sepaloid in Calochortus and Trillium. The ovary is half-inferior in Zygadenus elegans. The parts of the flower in Maianthemum are in twos, namely 4 perianth segments, 4 stamens, and 2 carpels.

1. Dioecious plants, climbing by means of tendrils; leaves net-veined; flowers in umbels; fruit a berry $=$ Smilax.

Plants not climbing. . . . . . . . . . . . . . . . . . . . . . . . 2

2. Plants with bulbs; the fruit is a capsule................... $\ldots$

Plants with corms or tubers.. $\ldots \ldots \ldots \ldots \ldots$

Plants with rootstocks or rhizomes..

3. Leaves linear; flowers in terminal racemes or panicles with small bracts; perianth persistent. . . . . . . . . . . . . . . . . . . . . . . . . . . . . . . . . . 4 Plants with strong odour when bruised; flowers in umbels, with spathe-like bracts= Allium.

Flowers usually solitary or few in number with leafy bracts; perianth-segments with a gland at the base.. . . . . . . . . . . . . . . . . . . . . . . . . . 6

4. Leaves basal; flowers blue or white; anthers versatile $=$ Camassia.

Stem leafy. . . . . . . . . . . . . . . . . . . . . . . . . . 5

5. Flowers nodding, greenish- or brownish-purple; perianth-segments without glands= Stenanthium.

Flowers erect, greenish- or yellowish-white, sometimes unisexual; perianth-segments with glands at the base $=Z$ ygadenus.

6. Bulb arising at the end of a short rhizome; bulb-scales overlapping; leaves narrow, grass-like $=$ Lloydia.

Scales of the bulb narrow and not overlapping; perianth-segments deciduous.. .. 7

7. Flowers nodding; perianth campanulate; the nectary is a pit at the base of each perianth segment; capsule angular = Fritillaria.

Leaves mostly in whorls; flowers erect or drooping; perianth-segments spreading or recurved, with a nectariferous groove at the base; anthers versatile =Lilium.

8. Leaves all basal; fruit a capsule.. $\ldots \ldots \ldots \ldots \ldots$

Stem leafy.................................... 11

9. Outer whorl of the perianth composed of narrow sepal-like segments; capsule septicidal $=$ Calochortus.

Both whorls of perianth alike; capsule loculicidal. . . . . . . . . . . . 10

10. Plants with several linear leaves; flowers in an umbel, with bracts; cuter whorl of stamens sometimes sterile=Brodiaea.

The corms arise on short rhizomes; there are two broad leaves; flowers 1-6 on each stem, bractless, nodding $=$ Erythronium.

11. Leaves alternate; flowers in a raceme, white, dioecious; fruit a capsule $=$ Chamaelirium.

Leaves in one or more whorls; flowers bisexual; fruit a berry............ 12 
12. Flower solitary, with a whorl of 3 leaves beneath it; berry red =Trillium.

There are 2 whorls of leaves and a sessile umbel of recurved flowers; berry purple $=$ Medeola.

13. Flowers solitary or umbellately arranged...................... 14

Flowers in a raceme or panicle.. $\ldots \ldots \ldots \ldots \ldots$

14. Ireaves basal, petioled; fruit a blue berry =Clintonia.

Leaves cauline, sessile.. . . . . . . . . . . . . . . . . . . . . 15

15. Flowers terminal. . . . . . . . . . . . . . . . . . . . . . . . . . 16

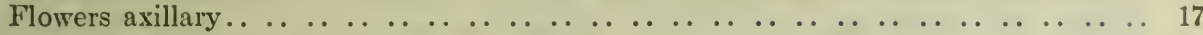

16. Downy plants with flowers in groups of one or more; fruit a berry.=Disporum.

Smooth plants with solitary flowers; fruit an angled or winged capsule $=$ Uvularia.

17. Rhizome with circular scars; perianth-segments united; fruit a blue berry=Polygonatum. Perianth segments separate; fruit a red berry =Streptopus.

18. Leaves linear; fruit a capsule . . . . . . . . . . . . . . . . . . . . . . . . . 19

Leaves ovate, lanceolate or elliptical.. . . . . . . . . . . . . . . . . . . . . . . . 20

19. Leaves mostly basal, 2-ranked, and equitant; flowers green or white, in a raceme or panicle; capsule septicidal = Tofieldia.

Stem leafy; flowers in a dense raceme, white; capsule loculicidal =Xerophyllum.

20. Fruit a capsule. . . . . . . . . . . . . . . . . . . . . . . . 21

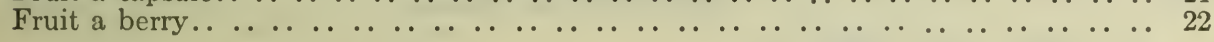

21. Leaves basal; flowers in a raceme; perianth-segments united =Aletris.

Downy plants with leafy stems; leaves broad, strongly veined, clasping; flowers sometimes unisexual, grouped in a panicle $=$ Veratrum.

22. Leaves petiolate, cordate at the base; perianth-segments and stamens 4 in number; ovary bilocular= Maianthemum.

Leaves sessile or nearly so; perianth-segments and stamens 6 in number $=$ Smilacina.

\section{Distrinution of Geinera}

Aletris farinosa (Star-grass; Colic-ront) E S. It grows in dry or sandy soil. Allium (Onion; Garlic) ESPW. $15 \mathrm{sp.}$

Brodiaea (Wild Hyacinth) W. 3 sp.

Calochortus (Mariposa Lily; Star-tulip) W. 3 sp.

Camassia (Camas) S W. 4 sp. Eastern Camas (C.esculenta) with blue flowers is confined to Southern Ontario.

Chamaelirium luteum (Blazing Star) S.

('lintonia (Queen-cup) NESW $2 \mathrm{sp}$. Yellow Clintonia (C. borealis) occurs in eastern woods.

Disporum (Fairy-bells) SPW. 5 sp. Downy Fairy-bells (D. lanuginosum) is confined to woods in the southern region.

Erythronium (Adder's Tungue: Dog's Tooth Violet) ESW. 9 sp. Yellow Adder's Tongue

(E. americanum) with yellow flowers is the only eastern species.

Fritillaria (Rice-root) W. $3 \mathrm{sp}$.

Lilium (Lily) ESPW. 6 sp.

Lloydia serotina (Alpine Lily) AW. It occurs in alpine situations.

Maianthemum (Wild Lily of the Valley) NESPW. 2 sp. Eastern Mayflower (M. canadense) extends from the eastern to the prairie region and occurs in moist woods.

Medeola virginiana (Indian Cucumber-root) ES. It occurs in moist woods.

Polygonatum (Solomon's Seal) ESP. 2 sp.

Smilacina (False Solomon's Seal) NESPW. $7 \mathrm{sp}$.

Smilax (Greenbrier) ESP. 4 sp Carrion-flower ( $S$. herbacea) is a herbaceous species with smooth stem occurring in the eastern and prairie regions, in woods.

Stenanthium occidentale (Bronze-bells) W. It grows in wet places in the mountains.

Streptopus (Twisted-stalk) ANESPIV. $4 \mathrm{sp.}$

Tofieldia (False Asphodel) ANESPW. $5 \mathrm{sp}$. The species occur mostly in alpine or northern localities. 
Trillium (Wake-robin) NESPW. 5 sp. Western Wake-robin (T. ovatum) is the only species in B.C.

Uvularia (Bellwort) ES. $2 \mathrm{sp.}$

Veratrum (False Hellebore) ESW. $2 \mathrm{sp.} \mathrm{American} \mathrm{White} \mathrm{Hellebore} \mathrm{(V.} \mathrm{viride)} \mathrm{occurs}$ in wet places and is the only species found in the east.

Xerophyllum tenax (Bear grass) W. It has whitish flowers and occurs in dry situations. Zygadenus (Death-camas) ESPW. $5 \mathrm{sp.}$

\section{AMARYLLIDACEAE}

Plants with corms; leaves basal; ovary inferior.=Hypoxis.

Plants with rhizomes; stem leafy; perianth-segments woolly; ovary half-inferior= Lophiola.

\section{Distribution of Genera}

Hypoxis hirsuta (Star-grass) S P. It has yellow flowers and occurs on dry soil. Lophiola americana (Woolly Star-grass) E.

\section{IRIDACEAE}

The two whorls of the perianth are unlike in shape; styles petaloid=Iris.

Stem compressed; perianth-segments all alike in shape; branches of the style filiform $=$ Sisyrinchium.

\section{Distribution of Genera}

Iris (Flag; Iris) NESPW. 5 sp.

Sisyrinchium (Blue-eyed grass; Golden-eyed grass) NESPW. 17 sp. Purple Star-grass (S. grandiflorum), a western species, has reddish-purple flowers.

\section{ORCHIDACEAE}

Perennial herbs, mostly with tuberous underground stems or fleshy roots. Leaves entire, sheathing. Flowers usually in bracted spikes or racemes, sometimes solitary, bisexual, zygomorphic. The 3 outer segments of the perianth are alike but one of the inner three, known as the lip (labellum) is markedly different in shape from the other two. There is a single stamen which is united with the style to form the column. The pollen grains are united in masses known as "pollinia" which vary from 2 to 8 in number. Ovary inferior, twisted, one-celled, with 3 parietal placentae. Fruit a capsule with numerous very minute seeds.

As exceptions to the above characters the leaves are petiolate in Aplectrum and whorled in Isotria.

In Cypripedium two of the sepals are frequently united and there are two stamens present.

1. Saprophytic plants, devoid of green colouring matter, with scaly leaves and flowers in

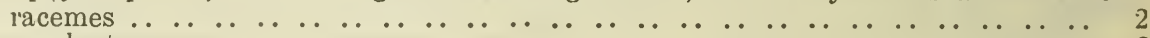

Green plants. .

2. Plants yellowish or purplish with coralloid rhizomes; two of the sepals are frequently united to form a short spur at the top of the ovary; lip ridged; pollinia waxy $=$ Corallorhiza.

Plants white with oreeping rhizome; lip saccate at the base; pollinia granulose $=$ Cephalanthera.

3. There is 1 green leaf present on the stem................... .

Two green leaves present on the stem; flowers in racemes or spikes... $\ldots \ldots \ldots \ldots \ldots$

Several green leaves present on the stem...................... . . . . 11

4. Flowers solitary; lip bearded. . . . . . . . . . . . . . . . . . . . . 5

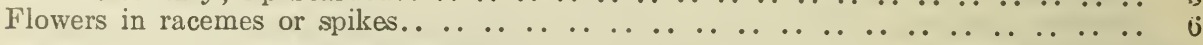

5. Stem a corm; leaf linear, protruding after flowering; lip with 3 white hairy ridges; pollinia 4, granular=Arethusa.

Roots fibrous; leaf lanceolate; there is a foliaceous bract beneath the flower; lip spatulate with yellow or white crest; pollinia 2, granular=Pogonia. 
Stem a corm and roots coralloid; leaf nearly as broad as long; lip divided into an upper and a lower lobe with a patch of yellow woolly hairs; pollinia 2, each 2-parted, waxy $=$ Cytherea.

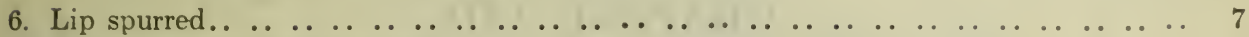

Lip not spurred; stem a corm. . . . . . . . . . . . . . . . . . . 8

7. Leaf obovate; perianth greenish-yellow; lip entire.= Habenaria obtusata.

Leaf oval or orbicular; perianth rose-colored; lip 3-lobed.=Orchis.

8. Leaf linear; lip bearded; pollinia $2=$ Calopogon .

Leaf elliptical; pollinia $4 . . \ldots \ldots \ldots \ldots \ldots \ldots \ldots \ldots \ldots$

9. Corm produced on an offset; leaf petiolate; flowers one inch in length.=Aplectrum.

Leaf sheathing at the base; flowers white or green, less than one-tenth of an inch long; lateral petals linear, much narrower than the sepals.= Microstylis.

10. Lip spurred. . . . . . . . . . . . . . . . . . . . . . . . 11

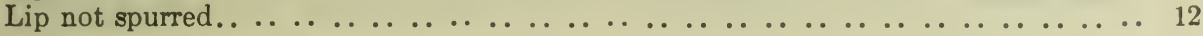

11. Leaves orbicular; flowers in a raceme; spur longer than the ovary $=$ Habenaria $\mathrm{sp}$.

Leaves obovate, clammy; flowers in a spike; sepals united to form a hood; lip undivided; spur shorter than the ovary.=Galeorchis.

12. Lip an inflated sac; anthers $2 .=$ Cypripedium acaule.

Lip not saccate; anther single... . . . . . . . . . . . . . . . . .

13. Plants with corms; leaves basal; lateral petals linear; pollinia 4 .=Liparis.

Plants with fibrous roots; leaves nearly opposite, about half way up the stem; pollinia 2, powdery.= Listera.

14. Flowers solitary. . . . . . . . . . . . . . . . . . . . . . . 15

Flowers in spikes or racemes.. . . . . . . . . . . . . . . . . . . . . . . . 16

15. Leaves alternate; lip saccate with inrolled edge; anthers $2 .=$ Cypripedium $\mathrm{sp}$.

Leaves 5 in a whorl; sepals linear; lip 3 -lobed.=Isotria.

16. Lip spurred.=Habenaria sp.

Lip without a spur.

17. Plants with rhizomes; leaves broad; lip saccate at the base, constricted in the middle, dilated at the top; pollinia granular.=Epipactis.

Roots thick and clustered; leaves mostly narrow; flowers in 1-3 rows on the spike, mostly white; upper sepal and lateral petals united; lip concave, with callosities at the base, embracing the column.=Spiranthes.

Leaves in a basal tuft, ovate; upper sepal and lateral petals united to form a hood; flowers white or greenish = Peramium.

\section{Distribution of Genera}

Aplectrum spicatum (Putty-root: Adam and Eve) ESP. It occurs in woods.

Arethusa bulbosa (Dragon's Mouth) E.S. It occurs in bogs.

Calopogon tuberosus (Grass-pink) ES. It occurs in bogs, and meadows.

Cephalanthera Austinae (Phantom-orchid) W. It occurs in woods.

Corallorhiza (Coral-root) NESW. 5 sp.

Cypripedium (Lady's Slipper) ESPW. 6 sp.

Cytherea bulbosa (Cleft-lip) NESW. It is found in mossy woods.

Epipactis (Helleborine) EW. 2 sp.

Galeorchis spectabilis (Hooded Orchid) ES. It occurs in woods.

Habenaria (Spur-orchid) ANESPW. 26 sp.

Isotria verticillata (Whorled Orchid) S. It occurs in woods.

Liparis Loeselii (False Twayblade) ESP. It occurs in wet places.

Listeria (Twayblade) NESW. 6 sp.

Microstylis (Adder's Mouth) ESP. 2 sp.

Orchis rotundifolia (Round-leaved Orchid) ANEPW. It is found in damp woods.

Peramium (Rattlesnake-plantain) ESW. 4 sp.

Pogonia ophioglossoides (Snake-mouth) ES. It occurs in swamps.

Spiranthes (Ladies' Tresses) ANESW. 5 sp. 


\section{CHAPTER VIII}

\section{APETALOUS DICOTYLEDONS-FAMILIES AND GENERA}

1. Green plants, parasitic on coniferous trees; leaves opposite, reduced to scales= Arceuthobium.

Plants rooted in the soil or living in water. . . . . . . . . . . . . . 2

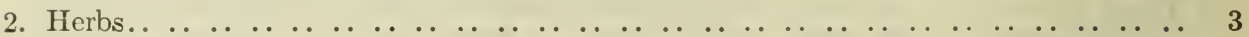

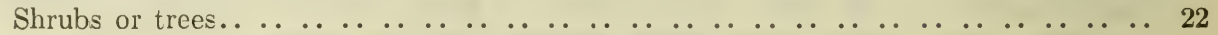

3. Water plants. . . . . . . . . . . . . . . . . . . . . . . . . . . . . 4

Land plants... . . . . . . . . . . . . . . . . . . . . . . . . . . . . . . . .

4. Leaves all simple. . . . . . . . . . . . . . . . . . . . . . . . 5

Some or all of the leaves divided into filiform segments.. $\ldots \ldots \ldots \ldots$

5. Leaves alternate. . . . . . . . . . . . . . . . . . . . . . . . . . . . . . . 6

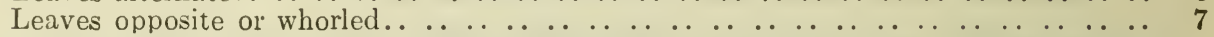

6. Leaves broad, cordate at the base=Saururus.

Leaves filiform =Myriophyllum tenellum.

7. Leaves opposite $=$ Callitriche.

Leaves whorled $=$ Hippuris.

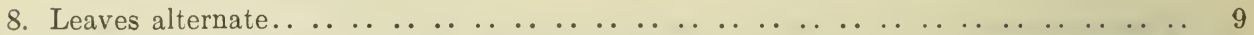

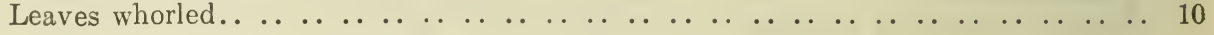

9. Plants rooted in mud; leaves pinnately lobed=Proserpinaca.

Plants attached to stones; leaves irregularly divided=Podostemon.

10. Free-floating plants without roots $=$ Ceratophyllum.

Plants rooted at the bottom $=$ Myriophyllum.

11. Flowers unisexual. ................................. 12

Flowers bisexual. . $\ldots \ldots \ldots \ldots \ldots$

12. Stigmas 2 ; fruit 1 -seeded, indehiscent, enclosed between 2 bracts $=$ Atriplex.

Filaments of the stamens bent inwards in the bud; stigma single; fruit 1-seeded, indehiscent, enclosed by 2-4 perianth segments=URTICACEAE (p. 27).

Fruit three-seeded, dehiscent=EUPHORBIACEAE (p. 27).

13. Leaves stipulate, the stipules free or forming a sheath around the stem. . . . . . 14

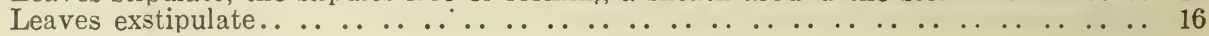

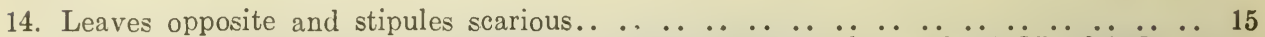
Leaves alternate and stipules forming a sheath above the node=POLYGONACEAE (p. 27).

15. Perianth-segments awned; style well developed=Paronychia.

Perianth-segments not awned; stigmas sessile =Anychia.

16. Leaves opposite; perianth coloured.. . . . . . . . . . . . . . . . . . . 17 Stem fleshy; leaves reduced to opposite scales; flowers sunk in the tissue of the stem Salicornia.

Leaves alternate. . . . . . . . . . . . . . . . . . . . . . . . . . . . 18

17. Bracts of the involucre united; pairs of leaves equal; fruit ribbed=Allionia.

Bracts of the involucre separate; pairs of leaves unequal; fruit winged=Abronia.

18. Fruit fleshy when ripe.. . . . . . . . . . . . . . . . . . . . . . 19

Fruit dry when ripe.. . . . . . . . . . . . . . . . . . . . . . . . . . . . . 20

19. Flowers in cymes; fruit 1-seeded, crowned by the perianth-segments=Comandra.

Flowers in racemes; fruit 10 -seeded $=$ Phytolacca.

20. Rhizome aromatic; flowers large and solitary; perianth-segments 3 in number; fruit a 6-celled capsule $=$ Asarum. 
Flowers small and numerous; perianth-segments $2-5$ in number; fruit 1 -seeded and indehiscent. . . . . . . . . . . . . . . . . . . . . . . . . . . . . . . . . . . 21

Flowers in groups with an involucre; perianth segments 6 , in two series; stamens 9; fruit indehiscent, angled or winged=Eriogonum.

21. Bracts and perianth segments scarious=AMARANTACEAE (p. 28).

No scarious bracts present; perianth segments greenish=CHENOPODIACEAE (p. 28).

22. Leaves pinnately compound.. . . . . . . . . . . . . . . . . . . . . 23

Leaves simple.. . . . . . . . . . . . . . . . . . . . . . . . . . . . . . . . 24

23. Outer part of fruit splitting when ripe into 4 segments; endocarp smooth or angled= Carya.

Outer part of fruit not splitting when ripe; woody part of fruit (endocarp) rugose= Juglans.

24. Fruit or adjacent parts fleshy when ripe..................... 25

Fruit a capsule; seeds with a tuft of hairs=SALICACEAE (p. 29).

Fruit dry when ripe, 1 -seeded, indehiscent. . . . . . . . . . . . . . . . . . . . . . . 29

25. Leaves covered with small scale-like hairs; the perianth-segments become fleshy and enclose the true fruit when ripe.. ........................ . . . . . 26

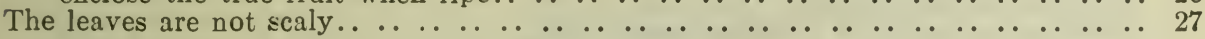

26. Leaves alternate; stamens $4=$ Elaeagnus.

Leaves opposite; stamens $8=$ Shephercia.

27. Plants with milky juice; perianth-segments becoming fleshy and enclosing the true fruit when ripe $=$ Morus.

No milky juice present; perianth not becoming fleshy; fruit a drupe.. . . . . . 28

2S. Bark fibrous and very tough; flowers bisexual, opening before the leaves; perianth yellowish $=$ Dirca .

Flowers unisexual; fruits stalked, solitary in the axils of ovate leaves $=$ Celtis.

Leaves aromatic; flowers in short catkins, unisexual; fruits covered with wax or resin= Myrica.

29. Shrubs with pinnatifid, sweet-scented leaves; perianth absent=Comptonia.

Trees with palmately lobed stipulate leaves; flowers in dense globular heads; perianth absent=Platanus.

Leaves neither pinnatifid nor palmately lobed.. . . . . . . . . . . . . . . . . 30

30. Shrubs with exstipulate leaves; flowers unisexual; stamens $2-5=$ CHENOPODIACEAE (p. 29).

Trees with asymmetrical leaves and deciduous stipules; flowers clustered in small umbels or racemes, appearing before the leaves; fruit with a broad wing =Ulmus.

Leaves with deciduous stipules; flowers unisexual, the staminate in catkins.. . . . 31

31. Styles 2 ; fruit with or without an involucre of bracts. . . . . . . . . . . . 32

Styles 3 or more; fruit with an involucre of bracts forming a cupule=FAGACEAE (p. 29).

32. There are three flowers in the axil of each bract of the staminate catkin, each with a perianth; there are 2-3 flowers in the axil of each bract of the pistillate catkin, which are without a perianth; fruit compressed, without a cupule-BETULACEAE (p. 29).

There is a single flower in the axil of each bract of the staminate catkin which is without a perianth; there are 2 flowers in the axil of each bract of the short pistillate inflorescence, which are provided with a perianth; the fruit has a cupule composed of bracts=CORYLACEAE (p. 29).

\section{Distribution of Genera}

Abronia (Umbrella-wort) PW. 3 sp.

Allionia (Sand-puffs) ESP. $4 \mathrm{sp}$.

Anychia canadensis (Forked Chickweed) ES.

Arceuthobium (Dwarf Mistletoe) E.PW. $4 \mathrm{sp}$. Eastern Dwarf Mistletoe (A. pusillum) occurs on Spruce and Tamarack in the eastern region only.

Asarum (Wild Ginger) ESW. 2 sp. Eastern Wild Ginger (A. canadense) occurs in eastern woods, while Western Wild Ginger $(A$. caudatum $)$ is confined to woods in the west. Atriplex (See page 28).

Callitriche (Water Starwort) NESPW. $4 \mathrm{sp.}$ 
Carya (Hickory) ES. 6 sp.

Celtis (Hackberry) ESW. 2 sp. Eastern Hackberry (C. occidentalis) and Western Hackberry ( $C$. Douglasii) are confined to the east and west respectively.

Ceratophyllum demersum (Hornwort) ESP.

Comandra (Bastard Toadflax) NESPW. 4 sp.

Comptonia peregrina (Sweet Fern) ESP. It occurs in dry soil.

Dirca palustris (Leatherwood; Wicopy) ES.

Elaeagnus commutata (Silver-berry) NEPW.

Eriogonum (See page 28).

Hippuris (Mare's Tail) ANEW. 3 sp.

Juglans (Walnut; Butternut) ES. $2 \mathrm{sp.}$ The Black Walnut (J. nigra) is confined to southern Ontario.

Morus rubra (Mulberry) S.

Myrica (Bog Myrtle; Bayberry) NESPW. 2 sp. Bog Myrtle (M. Gale) has brownish resinous fruits, while Bayberry ( $M$. carolinensis) has bluish waxy fruits and is confined to the eastern region.

Myriophyllum (Water-milfoil) ANESPW. $7 \mathrm{sp}$.

Paronychia (Whitlow-wort) P. 2 sp.

Phytolacca decandra (Pokeweed) S.

Platanus occidentalis (Sycamore) S.

Podostemon ceratophyllus (River-weed) ES.

Proserpinaca palustris (Mermaid-weed) ES.

Salicornia (See page 28).

Saururus cernuus (Lizard's Tail) S.

Shepherdia (Buffalo-berry) NESPW. 2 sp. Thorny Buffalo-berry (S. argentea) is confined to the prairie, while Smooth Buffalo-berry (S. canadensis) is widely distributed.

Ulmus (Elm) ESP. $3 \mathrm{sp}$. 


\title{
CHAPTER IX
}

\section{APETALOUS DICOTYLEDONS-URTICACEAE, EUPHORBIACEAE, POLYGONACEAE, AMARANTACEAE, CHENOPODIACEAE,}

\author{
URTICACEAE
}

1. Plants with stinging hairs.. . . . . . . . . . . . . . . . . . . . . . . . . . . . .

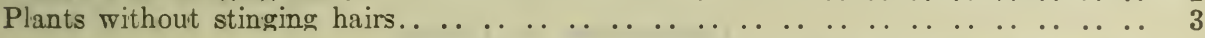

2. Leaves opposite; perianth segments in both kinds of flowers 4 in number $=$ Urtica.

Leaves alternate; perianth segments 5 in the staminate flowers, 4 in the pistillate flowers=Laportea.

3. Leaves alternate, exstipulate; flowers in axillary, cymose clusters with an involucre of bracts; some of the flowers are bisexual=Parietaria.

Leaves opposite, stipulate; flowers without an involucre. . . . . . . . . . . . . . 4

4. Plants annual, glabrous; perianth of the pistillate flower composed of 3 segments $=$ Pilea.

Plants perennial; perianth of the pistillate flower enclosing the fruit=Boehmeria.

\section{Distribution of Genera}

Boehmeria cylindrica (False Nettle) ES. It occurs in moist ground.

Laportea divaricata (Wood-nettle) ES. It occurs in woods.

Parietaria pennsylvanica (Pellitory) ESPW. It occurs on dry rocks and banks.

Pilea pumila (Clearweed) ES. It occurs in wet shaded situations.

Urtica (Nettle) ESPW. 5 sp.

\section{EUPHORBIACEAE}

Plants with milky juice; flowers enclosed in a cup-shaped involucre composed of bracts with glands between them; there is a single-stalked pistillate flower in the centre surrounded by a number of staminate flowers each of which consists of a single stamen= Euphorbia.

Plants without milky juice; perianth of the staminate flowers 4-parted, of the pistillate 3-5 parted; the pistillate flower is subtended by a foliaceous bract=Acalypha.

Distribution of Genera.

Acalypha virginica (Three-seeded Mercury) ES.

Euphorbia (Spurge) ESPW. 10 sp.

\section{POLYGONACEAE}

1. Plants without stipules=Eriogonum.

Stipules present. . . . . . . . . . . . . . . . . . . . . . . . . . . . 2

2. Annual plants with an involucre of bracts under the group of flowers; perianth-segments 3 in number $=$ Koenigia.

Flowers without an involucre. . . . . . . . . . . . . . . . . . . . . . . . . . . . . . 3

3. Perianth-segments 4 ; styles $2 \ldots \ldots \ldots \ldots \ldots \ldots \ldots$ Perianth-segments 5, often petaloid. stamens $3-8$; styles $2-3=$ Polygonum.

Perianth-segments 6 , the 3 inner ones becoming winged in fruit; stamens 6 ; styles $3=$ Rumex.

4. Leaves reniform; stamens 6 ; fruit winged $=$ Oxyria.

Leaves ovate-lanceolate; stamens 4 ; fruit biconvex, shining $=$ Tovara. 


\section{Distribution of Geniera}

Eriogonum (Umbrella-plant) PW. 12 sp.

Koenigia islandica (Arctic Knotweed) AW.

Oxyria digyna (Mountain-sorrel) ANEW.

Polygonum (Knotweed; Tear-thumb; Smartweed) NESPW. $51 \mathrm{sp.}$

Rumex (Dock; Sorrel) ANESPW. 14 sp.

Tovara virginiana (Virginian Knotweed) ES.

\section{AMARANTACEAE}

There is a perianth of 3-5 segments which is persistent=Amarantus.

The staminate flowers have a perianth of 5 segments while the pistillate flowrs have no perianth $=$ Acnida .

\section{Distribution of Genera}

Acnida altissima (Water hemp) ES. It is an annual, occurring in wet places. Amarantus (Pigweed) ESPW. 3 sp.

\section{CHENOPODIACEAE}

1. Fleshy-stemmed plants with opposite branches and opposite leaves which are reduced to scales; flowers sunk in the tissue of the stem = Salicornia.

Leaves alternate................................ . . . . . 2

2. Plants with spiny branches or spine-tipped leaves; perianth-segments forming a winglike expansion surrounding the mature fruit. . . . . . . . . . . . . . . . 3

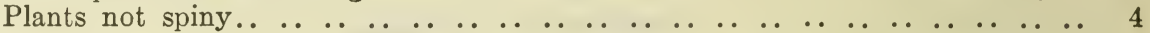

3. Shrubby plants with spiny branches, fleshy leaves and unisexual flowers = Sarcobatus. Annual herbs with fleshy spine-tipped leaves and bisexual flowers $=$ Salsola .

4. Flowers unisexual; pistillate flowers without a perianth but enclosed between 2 bracts. 5 Flowers bisexual. . . . . . . . . . . . . . . . . . . . . . . . . . . . . . . . . . . 6

5. Shrubby plants with stellate hairs; the staminate flower has 4 perianth-segments; bracts of the pistillate flower covered with silky hairs = Eurotia .

Mostly herbs with scurfy scales; the staminate flower has 4 or 5 perianth-segments; bracts of the pistillate flower not hairy $=$ Atriplex.

6. Flowers in globose, axillary sessile heads; perianth becoming fleshy and bright red in fruit $=$ Blitum .

Perianth not fleshy when mature....................... . . 7

7. There is a single perianth-segment; stamens $1-3 \ldots \ldots \ldots \ldots \ldots$

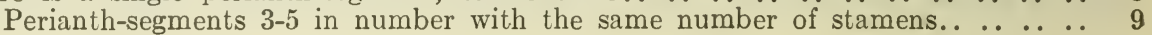

8. Leaves 3-lobed; flowers in axillary clusters $=$ Monolepis.

Leaves linear; flowers solitary in the axils of leaf-like bracts $=$ Corispermum.

9. Leaves linear, fleshy, sessile, entire $=$ Suaeda

Leaves not fleshy, usually broad and petiolate.. . . . . . . . . . . . . . 10

10. Perianth when mature with a broad wing surrounding the fruit $=$ Cycloloma.

Perianth not winged when mature $=$ Chenopodium.

\section{Distribution of Genera}

Atriplex (Orache) ESPIV. 8 sp.

Blitum capitatum (Strawberry Blite) ESPIV. It is an annual species in which the cluster of fruits resembles a strawberry.

Chenopodium (Goosefoot) ESPW. $10 \mathrm{sp.}$

Corispermum (Bug-seed) ANESPW. $3 \mathrm{sp.}$

Cycloloma atriplicifolium (Winged Pigweed) ESP. It is an annual plant.

Eurotia lanata. (IVinter-fat) P.

Monolepis nuttalliana (Wild Spinach) PW. It is an annual plant.

Salicornia (Glasswort) EPIV. 6 sp.

Salsola Kali (Prickly Saltwort) E. It is an annual, occurring on the sea-shore.

Sarcobatus vermiculatus (Greascwood) PW.

Suaeda (Seablite) EPW. 8 sp. 


\section{CHAPTER X}

\section{APETALOUS DICOTYLEDONS - SALICACEAE, FAGACEAE, BETULACEAE, CORYLACEAE.}

\section{SALICACEAE}

Buds covered by a single scale; bracts beneath the flowers entire; there is a nectariferious gland at the base of the flower; stamens 2-10 in number $=$ Salix.

Buds covered by several scales; bracts beneath the flowers fimbriate; stamens variable, or more than $10=$ Populus.

\section{Distribution of Genera}

Populus (Poplar; Aspen; Cottonwood). ANESPW. . 8 sp.

Salix (Willow) ANESPW. 96 sp.

\section{FAGACEAE}

1. Staminate flowers in heads; cupule composed of 4 valves and containing two triangular nuts $=$ Fagus.

Staminate flowers in elongated catkins; nut more or less rounded.. . . . . . . 2

2. Cupule globose, prickly, opening by 2 or 4 valves and containing 2 or more nuts $=$ Castanea.

Cupule composed of numerous scales which form a cup enclosing a single nut $=$ Quercus.

\section{Distribution of Genera}

Castanea dentata (Chestnut) S.

Fagus grandifolia (Beech) ES.

Quercus (Oak) ESPW. 14 sp. Garry Oak (Q. Garryana) is the only species in the West.

\section{BETULACEAE}

The staminate flower has 2 bifid stamens; bracts of the pistillate catkins 3-lobed when mature and deciduous; fruit winged = Betula.

Staminate flower with 4 stamens; bracts of the pistillate catkins becoming woody and persistent; fruit rarely winged $=$ Alnus.

\section{Distribution of Genera}

Alnus (Alder) ESPIV. $6 \mathrm{sp.}$

Betula (Birch) ANESPW. 12 sp.

\section{CORYLACEAE}

1. The bract of the staminate flower has 2 subsidiary bracts within it; pistillate flowers in groups of 2-4; involucre large, leafy incised on the margin, enclosing a large nut $=$ Corylus.

Bract of staminate flower without subsidiary bracts; pistillate flowers in a short catkin; nut small.. . . . . . . . . . . . . .

2. Involucre when mature 3-lobed, leafy; open on one side; nut ribbed $=$ Carpinus.

Involucre when mature a bladder-like sac completely enclosing the smooth nut $=$ Ostrya.

\section{Distribution of Genera}

Carpinus caroliniana (Blue Beech; Hornbeam) ES.

Corylus (Hazelnut) ESPW. 2 sp. Beaked Hazelnut (C. rostrata) has the involucre prolonged into a long, tubular, bristly beak.

Ostrya virginiana (Ironwood) ES. 


\section{CHAPTER XI}

\section{CHORIPETALOUS DICOTYLEDONS-FAMILIES AND GENERA}

1. Spiny plants without proper leaves, or with minute leaves which fall off quite early $=$ CACTACEAE (p. 50).

Leafy plants............

2. Leaves all radical, either tubular or covered with tentacles, adapted for the capture

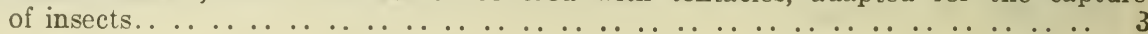
Plants with normal leaves..

3. Leaves tubular, with a winged expansion on one side and a lid-like lobe at the top. Flowers solitary, with an umbrella-shaped stigma $=$ Sarracenia.

Leaves flat, with glandular tentacles; flowers in a raceme=Drosera.

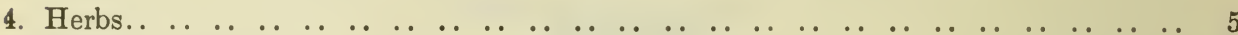

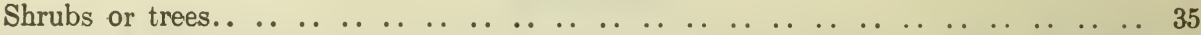

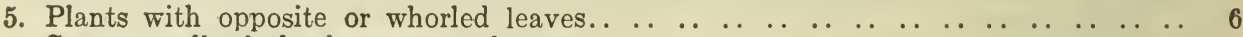

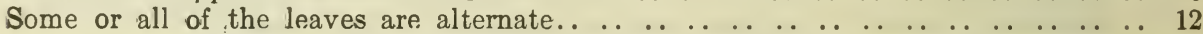

6. Perennial plants with an involucre of 4 white bracts beneath the head of flowers; ovary inferior; fruit a drupe=Cornus $\mathrm{sp}$.

There is no involucre of bracts beneath the inflorescence; carpels separate.. . 7

There is no involucre of bracts beneath the inflorescence; carpels united.. . . . . 8

7. Annual plants with simple leaves and axillary flowers; parts of the flower in fours $=$ Tillaea

Perennial plants with compound leaves; sepals 4, petaloid; petals absent: stamens numerous; achenes with persistent plumose styles=Clematis hirsutissima.

8. Ovary unilocular with free central placentation; sepals $2=$ PORTULACACEAE (p. 39)

Ovary unilocular with free central placentation; sepals 4-5=CARYOPHYLLACEAE (p. 39).

Ovary unilocular, with paietal placentation or several-celled with axile placentation. 9

9. Sepals united . . . . . . . . . . . . . . . . . . . . . . . . . . . . . 10

Sepals free; ovary superior.. $\ldots \ldots \ldots \ldots \ldots \ldots$

Sepals free; ovary inferior=OENOTHERACEAE (p.

10. Flowers in axillary clusters; there is an epicalyx of as many segments as the teeth of the calyx: petals 5 , purple; there are 5 long and 5 short stamens $=N e s a e a$.

Leaves with 3 or more principal veins; there is no epicalyx; stamens 8 , opening by pores $=$ Rhexia .

11. Aquatic plants with stipulate leaves and small axillary flowers; sepals $2-4=$ Elatine.

Annual plants with exstipulate leaves; sepals 2-3; petals white; stamens 4-6=Platystiomn

Leaves with translucent glands or black dots, exstipulate; sepals 5.=Hypericum.

12. Leaves stipulate. . . . . . . . . . . . . . . . . . . . . . . . . . . . . . . . . . . . . 13

Leaves exstipulate.. . . . . . . . . . . . . . . . . . . . . . . . . . 17

13. Leaves palmately veined; stamens numerous, united into a central column; carpels united=MALVACEAE ( $p .43)$.

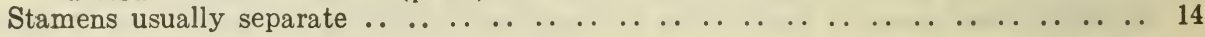

14. Flower zygomorphic; stamens 5 or 10 ; ovary composed of a single carpel or of 3

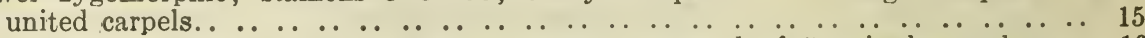

Flower actinomorphic; stamens $\ddot{5}$ or 10 ; ovary composed of 5 united carpels... 16 Flower actinomorphic; stamens usually numerous; ovary composed of one or more carpels which are either separate or enclosed by the fleshy receptacle=ROSACEAE (p. 43). 
15. Corolla composed of a standard, wings, and keel; stamens mostly 10 , more or less uniter by their filaments; fruit a legume=FABACEAE (p. 46).

One of the petals is saccate or spurred; stamens 5 , with the anthers more or less united; fruit a 3-valved capsule=VIOLACEAE (p. 48).

16. Leaves more or less divided palmately; fruit with a long beak, splitting into 5 segments from below upwards=Geranium.

Leaf composed of 3 leaflets: fruit not, beaked $=$ Oxalis.

17. Stamens more than 10 usually... . . . . . . . . . . . . . . . . . . . . . 18

Stamens 10 or less. . . . . . . . . . . . . . . . . . . . . . . . . . 22

18. Aquatic plants with simple floating leaves; petals mostly numerous=NYMPHAEACEAE (p. 37).

Land-plants mostly.

19. Carpels separate $=$ RANUNCULACEAE (p. 36).

Carpels united.

20. Sepals 5, all alike; ovary inferior, unilocular=Mentzelia.

Sepals 5, two being smaller than the other three; ovary superior; capsule 1-6-seeded $=$ CISTACEAE $(\mathrm{p}, 43)$.

Sepals 2-8 all alike; ovary superior...

21. Annual plants; sepals 4 , deciduous; ovary bilocular=Polanisia.

Perennial plants with fleshy roots and leaves all radical; sepals 2-8; ovary unilocular; capsule circumscissile at the base $=$ Levisia .

Plants with coloured juice: sepals 2, deciduous; ovary unilocular; capsule dehiscent by pores or valves $=$ PAPAVERACEAE (p. 40).

22. Ovary inferior. . . . . . . . . . . . . . . . . . . . . . . . . . . . . . . 23

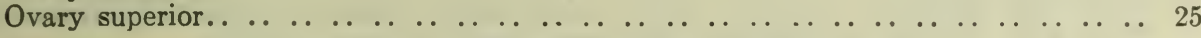

23. Parts of the flower arranged in fours=OENOTHERACEAE (p. 50).

Flowers mostly in umbels; parts of the flower arranged mostly in fives. . . . . . . . 24

24. Styles 2-5; fruit fleshy=ARALIACEAE (p. 51).

Stems usually hollow; styles 2, fruit a schizocarp=UMBELLIFERAE (p. 51).

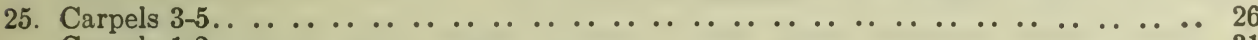

Carpels $1-2 \ldots \ldots \ldots \ldots \ldots \ldots$

26. One of the 3 sepals is petaloid and spurred; fruit an explosive capsule=Impatiens.

None of the sepals spurred; fruit not exploding. . . . . . . . . . . . . . 27

27. Sepals 2 ; ovary unilocular=PORTULACACEAF (p. 39).

Sepals $3-5 \ldots \ldots \ldots \ldots \ldots \ldots \ldots \ldots \ldots \ldots \ldots \ldots \ldots \ldots \ldots \ldots$

28. Stamens 5 , united at the base, with small staminodes between them; carpels fully united; fruit a capsule $=$ Linum.

Stamens 6-10; capels free or only partially united. . . . . . . . . . . . . . 29

29. Annual plants with axillary flowers; sepals, petals, and carpels 3 in number; fruit a schizocarp $=$ Floerkea.

Annual plants with axillary flowers; sepals $4-5$; fruit a schizocarp=Limnanthes.

Perennial plants mostly, with flowers in terminal cymes..............

30. Petals absent; fruit a capsule $=$ Penthorum.

Leaves fleshy; petals present; fruit composed of follicles $=$ Sedum.

31. Corolla zygomorphic or isobilateral....................... 32

Epicalyx present, corolla actinomorphic; petals 6 ; stamens $6=$ Lythrum.

There is no epicalyx; corolla actinomorphic................... 33

32. Sepals 2 , the 2 lateral ones large and coloured; petals 3 , united into a tube which is split on the back=Polygala.

Leaves divided; sepals 2 ; petals 4, the inner pair somewhat united at the tip; stamens 6 , in two sets of 3 each=FUMARIACEAE $(p .40)$.

33. Petals 4 ; carpels $2 \ldots \ldots \ldots \ldots \ldots \ldots \ldots \ldots \ldots \ldots \ldots \ldots \ldots \ldots \ldots \ldots \ldots \ldots$

Receptacle more or less cup-shaped; petals usually 5 ; stamens 5 - 10 ; carpels $2=$ SAXIFRAGACEAE (p. 48). 
There are several whorls in the perianth; petals 6 or more; anthers opening by valves: single carpel=BERBERIDACEAE p. 38).

34. Annual plants with trifoliolate leaves; stamens 6, all of the same length; ovary unilocular $=$ Cleome.

Stamens usually 6, four long and 2 short; ovary bilocular=CRUCIFERAE (p. 40).

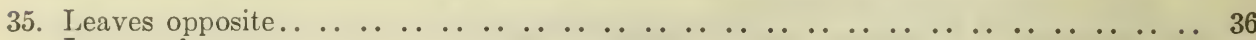

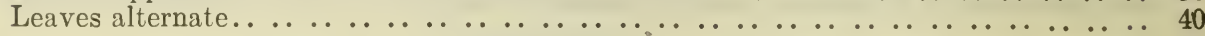

36. Petals 4 ; ovary inferior; fruit fleshy=Cornus $\mathrm{sp}$.

Climbing plants with 4-5 coloured sepals and no petals; fruit consists of achenes with persistent feathery style $=$ Clematis.

Fruit a winged schizocarp or a capsule.. . . . . . . . . . . . . . . . . . . . . . 37

37. Leaves palmately lobed or compound; fruit splitting when ripe into two one-seeded segments $=$ Acer.

Fruit a capsule................................ 38

38. Ieaves trifoliolate; sepals 5 ; capsule inflated, 3 -celled=Staphylea.

Leaves simple; sepals $4 . \ldots \ldots \ldots \ldots \ldots \ldots$. . . . . . . . . . . . . . . . . . 39

39. Leaves evergreen; capsule 2-celled; seeds with a white aril=Pachystima.

Leaves deciduous; capsule 3-5-celled; seeds with a red aril=Euonymus.

Leaves deciduous; petals large, white; capsule 4-celled=Philacelphus.

40. Leaves compound . . . . . . . . . . . . . . . . . . . . . . 41

Leaves simple.. . . . . . . . . . . . . . . . . . . . . . . . . . 47

41. Stamens numerous=ROSACEAE (p. 43).

Stamens 10 or less. . . . . . . . . . . . . . . . . . . . . . . . 42

42. Plants with digitately compound leaves, climbing by means of tendrils=Parthenocissus. Plants with trifoliate or pinnately compound leaves, without tendrils. . . . . . . 43

43. Fruit a legume...............................44

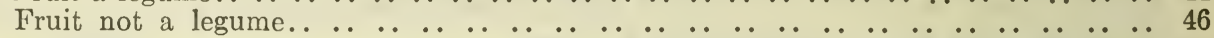

44. Shrubs with leaves once pinnate; the corolla consists of a single petal=Amorpha.

Trees with leaves once or twice pinnate; petals $3-5 \ldots \ldots \ldots \ldots \ldots \ldots$

45. Thorny plants; receptacle short, with $3-5$ sepals; legume thin=Gleditschia.

No thorns present; receptacle tubular, with 5 sepals; stamens 10 ; legume thick, coriaceous $=$ Gymnocladus.

46. Leaves evergreen, spinose-toothed; anthers opening by valves; fruit a several-seeded berry=Mahonia.

Leaves deciduous; fruit a one-seeded drupe $=$ Rhus.

Leaves with translucent oil-glands, aromatic; fruit dehiscent or 1-seeded and winged= RUTACEAE (p. 48).

47. Fruit dry when ripe, dehiscent or indehiscent.. . . . . . . . . . . . . . 48

Fruit fleshy when ripe.. . . . . . . . . . . . . . . . . . . . . . . . . . . . . . 54

48. Stamens numerous.. . . . . . . . . . . . . . . . . . . . . . . . . . . . . . . . 49

Stamens 10 or less. . . . . . . . . . . . . . . . . . . . . . . . . . . . 52

49. Leaves small, subulate or scale-like, imbricated; petals yellow $=$ Hudsonia.

Leaves broad, not imbricated. . . . . . . . . . . . . . . . . . . . . . . 50

50. Pistil apocarpous. . . . . . . . . . . . . . . . . . . . . . . . . . . . 51

Trees with the peduncle partly adnate to a broad bract; pistil syncarpous; fruit indehiscent $=$ Tilia.

51. Trees with aromatic bark and large solitary flowers; sepals 3 , petaloid; carpels many, on a conical receptacle $=$ MAGNOLIACEAE (p. 38)

Sepals generally 5 on a cup-like receptacle=ROSACEAE (p. 43).

52. Leaves cordate-orbicular with deciduous stipules; corolla zygomorphic; stamens 10; fruit a legume $=$ Cercis.

Leaves oval or ovate; corolla actinomorphic; stamens 4-5; fruit a capsule or schizo-

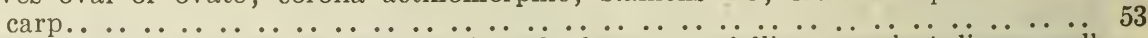

53. Flowers appearing late in the season when the leaves are falling; petals $\ddot{4}$, linear, yellow; stamens 4 ; capsule 2-celled, woody $=$ Hamamelis. 
Plants twining; petals 5 ; stamens 5 alternating with the petals; capsule 3 -celled; seed with a red aril=Celastrus.

Flowers in umbel-like clusters; stamens 5 , in fropt of the petals; fruit a schizocarp, splitting into 3 nutlets when ripe=Ceanothus.

54. Stamens more than 10 ; carpels usually separate.. . . . . . . . . . . . . 55

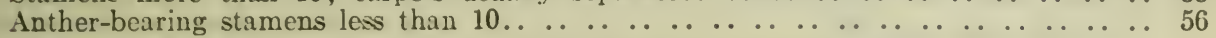

55. Twining plants with exstipulate, broad, palmately veined leaves; petals 6-8; fruit composed of drupes =Menispermum.

Aromatic plants with pinnately veined, exstipulate leaves; flowers solitary; petals 6 , . in 2 series; seed flat, enclosed in a fleshy aril=Asimina.

Leaves stipulate; petals 5 ; fruit composed of one or more drupes, or else pseudocarpous=ROSACEAE (p. 43).

56. Plants with palmately veined leaves climbing by means of tendrils; petals cohering in a cap and falling off without expanding $=$ Vitis

Plants without tendrils.. . . . . . . . . . . . . . . . . . . . . . . . . . . . $\ldots$

57. Ovary superior; some of the flowers unisexual. . . . . . . . . . . . . . 58

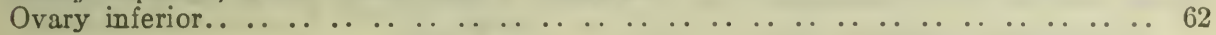

58. Leaves broad; fertile stamens $4-9 \ldots \ldots \ldots \ldots$

Dwarf shrubs with numerous small linear leaves which are channelled on the under side; stamens $3 . . \ldots \ldots \ldots \ldots \ldots \ldots$

59. Recoptacle cup-shaped; sepals 5 ; stamens alternating with the sepals; fruit severalseeded = Rhamnus.

Sepals 4-6; stamens alternating with the petals; fruit several-seeded.. . . . . . 61

Aromatic plants with translucent oil-glands; perianth in 2 whorls of 3 each; stamens in the staminate flowers in 3 whorls of 3 each; anthers opening by valves; fruit $1-$ seeded=LAURACEAE (p. 38).

60. Flowers solitary, axillary; style with 6-9 segments=Empetrum.

Flowers in terminal heads; style usually with 3 segments=Corema.

61. Flowers mostly in groups in the axils of the leaves; petals oval or obovate, slightly united $=$ Ilex.

Flowers solitary in the axils of the leaves; petals linear, not united; drupe red=Nemopanthus.

62. Flowers mostly unisexual, small, greenish, borne on axillary peduncles; sepals 5; stamens variable, mostly 10 ; ovary 1 -celled; fruit 1 -seeded $=N y s s a$.

Flowers bisexual; stamens $4-5$; fruit mostly with 2 or more seeds. . . . . . . . .

63. Leaves pinnately veined; petals 4 , stamens $4=$ Cornus alternifolia.

Plants often prickly; leaves palmately veined; petals 5 , stamens $5 . . . . . . .$.

64. Stem and leaves prickly; flowers in paniculate umbels; ovary 2-celled; fruit scarlet with 1 or 2 seeds=Echinopanax.

Stem frequently prickly; flowers mostly in racemes; ovary 1-celled; fruit several-seeded $=$ Ribes.

\section{Distribution of Genera}

Acer (Maple) NESPW. $10 \mathrm{sp.} \mathrm{Five} \mathrm{species} \mathrm{of} \mathrm{Maple} \mathrm{attain} \mathrm{the} \mathrm{rank} \mathrm{of} \mathrm{trees} \mathrm{one} \mathrm{foot}$ or more in diameter. Of these the Broad-leaved Maple (A. macrophyllum) is confined to the coast region of B.C. The fruits have sharp bristle-like hairs on the seed-bearing part. The Manitoba Maple ( $A$. Negundo) has compound leaves and is the only one growing naturally on the prairie. Of the three eastern tree-species the flowers in two open before the leaves unfold, namely, in the Silver Maple (A. saccharinum) and Red Maple (A. rubrum). The former has no petals and the wings of the fruit diverge widely, while the latter has red petals and the wings of the fruit are slightly incurved. In the Sugar Maple (A. Saccharum) the flawers develop at the same time as the leaves and the fruits consequently are much later in ripening. It is the principal species which is tapped for its sweet juice which is boiled down to make maple sugar and maple syrup.

Of the smaller species the Vine Maple (A. circinatum) is confined to the coast region of B.C. The branches frequently take root at the tip while the leaves are more or less circular in shape with 7 to 9 sharp-pointed lobes.

Amorpha (see page 47).

Asimina triloba (North American Papaw) S. 
Ceanothus (Redroot; New Jersey Tea) ESPW. 4 sp. Two species are eastern and 2 western. Of the latter the Sticky Laurel (C. velutinus) has gummy twigs and evergreen leaves while Buckbrush (C. sanguineus) has smooth twigs and deciduous leaves.

Celastrus scandens (Staff-tree; Climbing Bittersweet) ES.

Cercis canadensis (Redbud) S.

Clematis (see page 37 ).

Cleome serrulata (Pink Spider-flower) PW.

Corema Conradii (Broom-crowberry) E. In rocky ol sandy soil.

Cornus (Dogwood; Cornel) ANESPW. 13 sp.

The species with an involucre of bracts have the flowers in heards and bright red fruits. To this group belong the Bunchberry (C. canadensis) which is a small herb and two species which may attain the dimensions of trees, namely, Flowering Dogwood (C. florida) in southern Ontario and Western Dogiwood (C. Nuttallii) in the western part of B.C. Of the other species of Dogwood which have no involucre the Alternate-leaved Dogwood ( $C$. alternifolia) is an eastern species readily distinguished by its leaf arrangement.

Drosera (Sundew) ANESPW. $4 \mathrm{sp}$. Of the Sundews, which are bog plants, the Roundleaved Sundew ( $D$. rotundifolia) can be readily recognized by the orbicular leaf-blade.

Echinopanax horridum (Devil's Club) W. In Woods.

Elatine (Water-wort) ESPW. 2 sp. On margins of ponds.

Empetrum nigrum (Northern Crowberry) ANEW. On mountains.

Euonymus (Burning Bush; Strawberry-bush) 2 sp. S. The Strawberry-bush ( $E$. obovatus) has prostrate rooting twigs.

Floerkea proserpinacoides (False Mermaid) ES. In marshes.

Geranium (Cranesbill) ESPW. $10 \mathrm{sp.}$

Gleditschia triacanthos (Honey-locust) S.

Gymnocladus dioica (Kentucky Coffee Tree) S.

Hamamelis virginiana (Witch-hazel) ES.

Hudsonia (see page 43).

Hypericum (St. John's Wort) ESW. 15 sp. Orange Grass (H. gentianoides) is an annual with the leaves reduced to subulate scales and 5-10 stamens, occuring on sandy soil. Marsh St. John's Wort (H. virginicum) has a purplish corolla and usually 9 stamens in sets of 3 each; it is found in marshes.

Ilex (Holly) ES. 2 sp. The Inkberry (I. glabra) with evergreen leaves and black fruit grows in sandy soil while the Winterberry ( $I$. verticillata) has deciduous leaves, bright-red fruits and grows in marshes.

Impatiers (Jewel-weed) NESPW. 5 sp. In wet places. Spurless Jewel-weed (1. ecalcarata) a western species, has no spur.

Lewisia (see page 39).

Limnanthes (Lake-flower) W. 2 sp.

Linum (Flax) ESPW. 7 sp. Yellow Flax (L. rigidum) is a perennial species with yellow flowers found on the prairie.

Lythrum alatum (Winged Loosestrife) ESW. Perennial, with purple petals, occurring on marshy ground.

Mahonia (Oregon-grape) W. 2 sp.

Menispermum canadense (Moonseed) ES. In woods.

Mentzelia (Stick-leaf; Sand Lily) PW. $8 \mathrm{sp.} \mathrm{The} \mathrm{only} \mathrm{species} \mathrm{found} \mathrm{on} \mathrm{the} \mathrm{prairie} \mathrm{is}$ the Sand Lily ( $M$. decapetala). Of the 10 yellowish apparent petals 5 are really staminodes.

Nemopanthus mucronata (Mountain-holly) ES. In marshes.

Nesaea verticillata (Water-willow) S. Perennial, occurring in swamps.

Nyssa sylvatica (Black Gum). In marshes.

Oxalis (Wood-sorrel) ESPW. 4 sp. White Wood-sorrel (O. Acetosella) has a creeping stem, solitary white flowers with purple veins, and grows in woods.

Pachystima (Mountain-lover) W. 3 sp.

Parthenocissus quinquefolia (Virginian Creeper) ESP. In woods.

Penthorum sedoides (Ditch-stonecrop) ES. In wet places.

Philadelphus (see page 49).

Platystigma (see page 40 ).

Polanisia (Clammy Weed) ESPIV. $2 \mathrm{sp.}$ 
Polygala (Milkwort) NESP. $6 \mathrm{sp}$. Whorled Milkwort ( $P$. verticillata) has whorled leaves; Seneca Snakeroot ( $P$. Senega) has white flowers in a loose spike; Fringed Mdlkwort ( $P$. paucifolia) has few large rose-purple flowers in the axils of the upper leaves.

Rhamnus (Buckthorn) NESW. $2 \mathrm{sp.}$ Alder-leaved Buckthorn (Rhamnus alnifolia) has no petals, mostly unisexual flowers, and occurs in swamps; Sacred Bark (R. Purshiana) occurs only in woods in B.C

Rhexia virginica (Meadow-beauty) S. It occurs in swamps.

Rhus (Sumac) ESPIV. 6 sp. Three species have pinnately compound leaves, flowers in dense terminal panicles, and occur on dry soil. Of these Dwarf Sumac ( $R$. copallina) has the axis of the leaf winged, Staghorn Sumac ( $R$. hirta) is covered with velvety hairs, while Smooth Sumac ( $R$. glabra) is glabrous. Poison Elder (R. Vernix) has pinnately compound leaves, flowers in loose axillary panicles, and ocours in swamps. Two species have trifoliolate leaves, namely, Scented Sumac ( $R$. crenata) with flowers which unfold before the fragrant leaves and with red fruits, and Poison Ivy (R. Toxicodendron) with greenishwhite furrowed fruits.

Ribes (sce page 49).

Sarracenia purpurea (Pitcher-plant; Indian Cup) NESW. It occurs in bogs.

Sedum (Stonecrop) ANESPW. 8 sp.

Staphylea trifolia (Bladder-nut) ES.

Tilia (Basswood) ES. $2 \mathrm{sp.}$

Tillaca (Pigmy-weed) ESW. $2 \mathrm{sp.} \mathrm{In} \mathrm{muddy} \mathrm{situations.}$

Vitis (Grape) ES. 3 sp. 


\section{CHORIPETALOUS DICOTYLEDONS - RANUNCULA- CEAE, NYMPHAEACEAE, MAGNOLIACEAE, LAURACEAE, BERBERIDACEAE}

\section{RANUNCULACEAE}

The general characters of this family are as follows: They are mostly perennial herbs with alternate, divided, exstipulate leaves with sheathing bases. The inflorescence is typically cymose in development although in some cases it resembles a raceme. The parts of the flower usually have a spiral arrangement on an elongated receptacle. The actinomorphic flower is the common type. The sepals vary in number and are usually brightly coloured and deciduous. Petals may be absent, or, if present, are more or less tubular and secrete honey. The stamens are numerous. The pistil is superior and is composed of a variable number of separate carpels. The ovary may contain a single ovule in which case the fruit is an achene, or several ovules in which case the fruit is usually a follicle. In a few cases the fruit is a berry.

1. Mostly woody plants with opposite leaves, generally climbing by means of their petioles; petals absent; styles persistent, feathery=Clematis.

Herbaceous plants with alternate or radical leaves.. . . . . . . . . . . . . . 2

2. Flowers zygomorphic. . $\ldots \ldots \ldots \ldots \ldots \ldots$

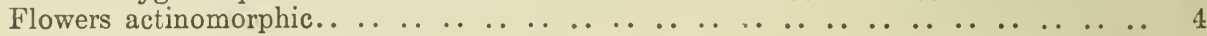

3. Sepals 5, the posterior one spurred; petals small, $2-4$ in number; the posterior 2 are spurred; fruit composed of 1-5 follicles=Delphinium.

Sepals 5, the posterior one shaped like a hood or helmet; petals small, $2-5$ in number; the posterior two are hooded, stalked, concealed in the hood-like sepal; imuit composed of 3-5 follicles=Aconitum.

4. Each carpel has usually 2 or more ovules and when ripe becomes a follicle or berry. 5

Each carpel contains a single ovule and becomes an acheme when ripe.. . . . . 11

5. Sepals 5; petals 5, tubular, prolonged at the base into spurs=Aquilegia.

Petals, if present, not spurred.. . . . . . . . . . . . . . . . . . . . . . . . . 6

6. Flowers grouped in apparent racemes; both sepals and petals present........ 7 Flowers solitary or in few-flowered inflorescences which are not of the racemose type. 8

7. Pistil composed of a single carpel; fruit a berry=Actaca.

Fruit composed of 1-3 follicles=Cimicifuga.

8. Leaves reniform or palmately lobed.. $\ldots \ldots \ldots \ldots$

Leaves ternately or pinnately compound.. . . . . . . . . . . . . . . . . . 10

9. Leaves palmately lobed; flowers solitary; sepals 3 ; petals none; carpels many, each giving rise to a crimson berry=Hydrastis.

Leaves reniform; flowers few; sepals 5 or more; petals none; carpels 5 or more, each giving rise to a follicle $=$ Caltha.

Leaves palmately parted; flowers usually solitary; sepals 5 or more; petals 5 or more, secreting honey in a pit at the base; carpels 5 or more, each giving rise to a follicle $=$ Trollius.

10. Plants with yellow, slender, rhizomes and radical evergreen leaves consisting of 3 or 5 leaflets; sepals 5 or more; petals 5 or more, hooded; fruit consisting of stalked follicles $=$ Coptis.

Plants with fibrous or tuberous roots and leaves twice or thrice ternately divided; sepals 5, petaloid; petals none; fruit consisting of few follicles=Isopyrum.

11. Annual plants with basal linear leaves and solitary flowers; sepals 5 , spurred at the base; petals 5 or more, sometimes none, with a honey-gland at the top; truit composed of numerous achenes on a long spike-like receptacle=Myosurus.

Mostly perennial plants; leaves rarely linear; sepals not spurred.. . . . . . . . 12 
12. Sepals 5 , petals 5, with a nectariferous pocket at the base=Ranunculus.

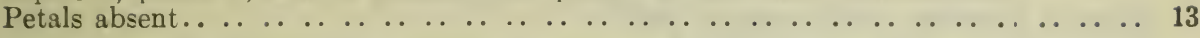

13. Plants with an involucre of leaves or tracts beneath the flowers........... . . 14

There is no involucre present. . . . . . . . . . . . . . . . . . . . . . . 15

14. Leaves radical, evergreen, 3-lobed; flowers solitary; involucre of 3 undivided bracts placed just beneath the calyx=Hepatica.

Leaves radical, digitately divided; flowers solitary; involucre of 3 deeply lobed bracts which are at a distance from the flower; styles persistent, plumose $=$ Pulsatilla.

Plants with tuberous roots; involucre of several stalked leaves below the group of flowers; achenes ribbed, glabrous=Syndesmon.

Mostly plants with rhizomes and palmately divided leaves; involucre of 3 leaf-like bracts distant from the flower; achenes compressed, often with woolly hairs; style not plumose $=$ Anemone .

15. Leaves palmately lobed; flowers bisexual; sepals $3-5=$ Trautvetteria.

Leaves ternately compound; flowers frequently unisexual; sepals 4-5; achenes usually ribbed = Thalictrum.

\section{Distribution of Genera}

Aconitum (Monkshood) AW. 3 sp.

Actaea (Baneberry) ESPW. $3 \mathrm{sp.}$ White Baneberry ( $A$. alba) has white berries. All the species occur in woods.

Anemone (Wind-flower; Anemone) ANESPW. 19 sp.

Aquilegia (Columbine) ESPW. 5 sp. Wild Columbine (A. canadensis) with scariet flowers is the only eastern species.

Caltha (Marsh Marigold) ANESPW. 6 sp. The only species in the east is the Eastern Marsh Marigold (C. palustris) which has vellow flowers. The only western species with flowers of this colour is the Yellow Marsh Marigold ( $C$. asarifolia). All the species occur in wet ground or in water.

Cimicifuga (Bugbane; Snakeroot) SW. 2 sp. Black Snakeroot (C. racemosa) is found in Ontario while Bugbane ( $C$. elata) is western.

Clematis (Virgin's Bower) NESW. $5 \mathrm{sp}$. Two species are eastern and three western. Of the latter group Woolly Clematis ( $C$. hirsutissima) is a herb, White Virgin's Bower (C. ligusticifolia) has white flowers, while Blue Virgin's Bower ( $C$. columbiana) has blue or purple flowers.

Coptis (Gold-thread) ANESW. 2 sp. Western Gold-thread ( $C$. asplenifolia) has 5 leaflets and occurs in the west only. Common Gold Thread ( $C$. trifolia) is of wide distribution and has 3 leaflets only. Both species occur in woods.

Delphinium (Larkspur) APW. $13 \mathrm{sp}$.

Hepatica (Liver-leaf) ES. 2 sp.

Hydrastis canadensis (Golden Seal) S. Occurs in woods.

Isopyrum biternatum (False Rue) S. Occurs in moist woods.

Myosurus (Mousetail) ESPW. $4 \mathrm{sp}$. Found growing on mud.

Pulsatilla (Pasque Flower) PW. 2 sp.

Ranunculus (Crowfoot; Buttercup) ANESPW. 54 sp.

Syndesmon thalictroides (Rue-anemone) S. Occurs in woods.

Thalictrum (Meadow-rue) ANESPW. 9 sp.

Trautvetteria grandis (False Bugbane) W. Occurs in woods.

Trollius (Globe-flower) W. 2 sp. Both species occur on wet ground.

\section{NYMPHAEACEAE}

1. Leaves peltate; carpels separate. . . . . . . . . . . . . . . . . . . . . . 2

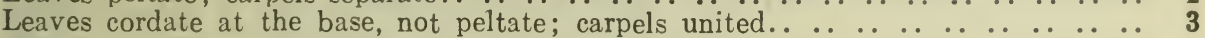

2. Submerged parts covered with a gelatinous secretion; leaves elliptical; flowers purple; sepals 3 ; petals $3=$ Brasenia.

Leaves orbicular; flowers pale-yellow: sepals 4-5; petals numerous; carpels sunk in pits in the obconical receptacle $=$ Nelumbo.

3. Flowers yellow; sepals 5-12; petals small, numerous, stamen-like, attached, like the numerous stamens, under the ovary $=N$ ymphozanthus (Nuphar).

Flowers white; sepals 4 ; petals large, numerous, attached to the ovary; stamens numerous, also attached to the ovary; fruit ripening under the water $=N y$ mphaea. 


\section{Distribution of Gener.}

Brasenia Schreberi (Water-shield) ESW.

Nelumbo lutea (American Lotus) S.

Nymphaea (White Waterlily) NESP. $3 \mathrm{sp.}$ Tuberous White Waterlily ( $N$. tuberosa) has lateral tubers on the rhizome, leaves green on both sides and almost scentless flowers. It occurs oniy in southern Ontario.

Nymphozanthus (Yellow Waterlily) NESPW. $3 \mathrm{sp}$. Western Yellow Waterlily ( $N$. polysepalus) has 8-12 sepals and is confined to the western region.

\section{MAGNOLIACEAE}

Leaves broadly oval; anthers opening inwards: fruits dehiscent when ripe=Magnolia.

Leaves with 4-6 lobes, truncate; anthers opening outwards; fruits samaroid, indehiscent= Liriodendron.

\section{Distribution of Genera}

Liriodendron Tulipifera (Tulip-tree) S.

Magnolia acuminata (Cucumber-tree) S.

\section{LAURACEAE}

Trees with entire ovate or 3-lobed leaves; anthers 4-celled, 4-valved; fertile flowers with 6 rudimentary stamens; drupe blue=Sassafras.

Shrubs with entire mostly obovate leaves; anthers 2-celled, 2-valved; fertile flowers with 12 or more staminodes; drupe red=Benzoin.

\section{Distribution of Genera}

Benzoin aestivale (Spice-bush; Benjamin Bush) S.

Sassafras variifolium (Ague-tree) S.

\section{BERBERIDACEAE}

1. Shrubs with pinnately compound leaves=Mahonia.

Herbs; leaves not pinnately compound. . . . . . . . . . . . . . . . . . . . . 2

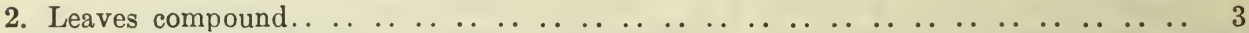

Leaves palmately lobed. . . . . . . . . . . . . . . . . . . . . . . . . 4

3. Leaves basal, composed of 3 leaflets; flowers in a spike; perianth absent $=$ Achlys.

Leaves triternately compound; sepals 6 ; petals 6 , hooded; the ovary bursts and disappears at an early stage and the 2 large blue seeds are supported on stout stalks= Caulophyllum.

4. Leaves basal, bilobate; sepals 4 ; petals 8 ; stamens 8 ; fruit a capsule, opening half-way round by a lid=Jeffersonia.

Lower leaves 5-9-lobed and peltate; flower large, white, solitary, terminal between 2 leaves; sepals 6 ; petals $6-9$; stamens twice as many as the petals; fruit a berry= Podophyllum.

\section{Distribution of Genera}

Achlys triphylla (Vanilla-leaf) W.

Caulophyllum thalictroides (Blue Cohosh) ES.

Jeffersunia diphylla (Twin-leaf) S.

Mahonia (Oregon-grape) W. 2 sp.

Podophyllum peltatum (May-apple, Wild Mandrake) ES. 


\title{
CHORIPETALOUS DICOTYLEDONS - PORTULAC- ACEAE, CARYOPHYLLACEAE, PAPAVERACEAE, FUMARIACEAE, CRUCIFERAE
}

\author{
PORTULACACEAE
}

1. Leaves all radical. . . . . . . . . . . . . . . . . . . . . . . . 2

Some of the leaves are cauline and opposite or alternate. . . . . . . . . . . 3

2. Sepals 2 scarious and deciduous; stamens numerous; capsule 3 -valved, with numerous seeds=Talinum.

Sepals 2-8, persistent; capsule circumscissile, many-seeded=Lewisia.

3. Annual plants with opposite leaves; petals 3 ; stamens 3 ; seeds $3=$ Montia.

Annual plants with alternate leaves and flowers in bracteate racemes; petals $3-5$; stamens $3-15$; seeds many=Calandrinia.

Annual or perennial plants with corms or stolons; some of the leaves are usually opposite; flowers in racemes; petals 5; stamens generally 5; seeds $3-6=$ Claytonia.

\section{Distuibution of Genera}

Calandrinia (Red Maids) W. 2 sp.

Claytonia (Spring Beauty; Miner's Lettuce) ESPW. $18 \mathrm{sp.}$

Lewisia (Bitter Root; Bread-root) W. 3 sp. Bitter-root (L. rediviva) has solitary flowers with 6-8 sepals and 12-16 rose-coloured petals. It occurs on the dry belt of B.C.

Montia fontana (Water-blinks) ANEW:. In wet places.

Talinum spinescens (Rock-pink) W. Occurs in rocky places.

\section{CARYOPHYLLACEAE}

The members of this family are mostly herbs with opposite simple leaves which are usually exstipulate. The inflorescence is typically a dichasial cyme. The flowers are bisexual. Sepals 5 in number, free or united. Petals 5, free. Stamens mostly 10. Carpels united, $2-5$ in number. Ovary superior, unilocular, with free-central placentation and numerous 'ovules. Fruit a capsule opening at the top by teeth which are equal in number to the carpels or twice as many. Embryo curved.

1. Sepals free. . . . . . . . . . . . . . . . . . . . . . . . . . 2

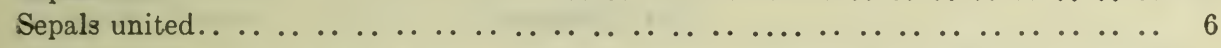

2. Stipules present, scarious $=$ Spergularia.

Stipules absent. . . . . . . . . . . . . . . . . . . . . . . . . . . . . . . 3

3. Petals deeply 2-cleft; capsule opening by twice as many equal teeth as there are

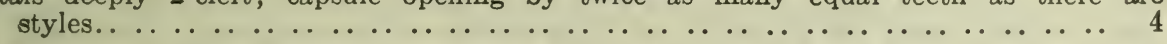

Petals entire or only emarginate; valves of the capsule equal at first to the number of the styles, sometimes becoming cleft afterwards................. . . . . 5

4 Styles 3, rarely 5; capsule short, ovoid=Stellaria.

Styles 5 ; capsule cylindrical, often curved $=$ Cerastium.

5. Tufted plants with subulate leaves; flowers mostly axillary on elongated pedicels; sepals $4-5$; stamens as many or twice as many; styles as many as the sepals=Sagina.

Plants often tufted, with broad or filiform leaves; flowers in terminal cymes or solitary in the axils; sepals usually 5 and stamens 10 ; styles usually $3=$ Minuartia.

6 Styles 3 ; capsule usually septate at the base=Silene.

Styles 5; capsule 1-celled to the base $=$ Lychnis. 


\section{Distribution of Genera}

Cerastium (Mouse-ear Chickweed) ANESPW. 17 sp.

Lychnis (Campion) ANESPW. 9 sp.

Minuartia (Sandwort) ANESPW. $32 \mathrm{sp.} \mathrm{Sea} \mathrm{purslane} \mathrm{(M.peploides)} \mathrm{has} \mathrm{long} \mathrm{rhizomes,}$ broad fleshy leaves, and axillary white flowers with a glandular disc below the ovary. It occurs on sand on both the Atlantic and Pacific coasts.

Sagina (Pearlwort) ANEW. 7 sp.

Silene (Catchfly; Campion) ANESPW. $10 \mathrm{sp.}$

Spergularia (Sand-spurry) NEPW. $6 \mathrm{sp.}$

Stellaria (Chickweed; Stitchwort ANESPW. 19 sp.

\section{PAPAVERACEAE}

Annual plants without coloured juice; leaves opposite, entire; stamens $4-6$; carpels $3=$ Platystigma.

Plants with milky juice; leaves alternate, lobed; stamens numerous; carpels 4 or more; capsule opening by pores=Papaver.

Plants with rhizomes and basal palmately lobed leaves; juice red; flowers solitary, white; petals 8-16; stamens numerous; carpels $2=$ Sanguinaria.

\section{Distribution of Genera}

Papaver (Poppy) AW. 2 sp.

Platystigma oreganum (Cream-cups) W. On sandy soil.

Sanguinaria canadensis (Bloodroot) ES. It is found in woods.

\section{FUMARIACEAE}

1. Flowers isobilateral, the 2 outer petals being spurred at the base. . . . . . . . Biennial leafy plants with only 1 petal spurred at the base=Corydalis.

2. Perennial plants with small tubers and basal leaves=Dicentra.

Biennial leafy plants, climbing by twisting of the leaf-stalks=Adlumia.

\section{Distribution of Genera}

Adlumia fungosa (Climbing Fumitory) ES.

Corydalis (Corydalis) ESPW. $3 \mathrm{sp}$. Pink Corydalis (C. sempervirens) has pink flowers with a yellow tip; it occurs in rocky places.

Dicentra (Dutchman's Breeches; Bleeding Heart) ESW. 4 sp. One-flowered Bleeding Heart (D. uniflora) with solitary flowers, is confined to B.C.

\section{CRUCIFERAE}

Herbs with alternate, exstipulate leaves. Inflorescence a raceme without bracts. Sepals in 2 whorls of 2 each, deciduous. Petals 4 , separate. There are 4 long and 2 short stamens. Carpels 2, united. Ovary superior, 2-celled, with the ovules attached at each edge of the partition. Fruit a siliqua or silicula, sometimes indehiscent, or breaking into 1-seeded joints. Embryo curved, the radicle sometimes lying along the edge of the cotyledons (pleurorrhizal form) or lying along the middle of the back of one of the cotyledons (notorrhizal form). Sometimes the cotyledons are folded, with the radicle between the folds.

1. Annual plants; fruits indehiscent and 1-seeded or breaking across into 1-seeded seg-

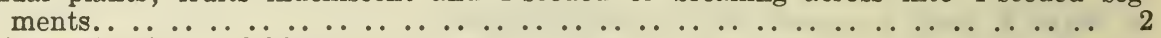

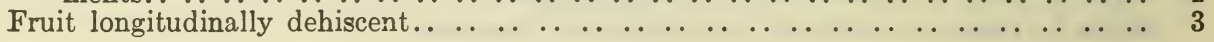

2. Plants with branched hairs; petals white or none; fruit orbicular, 1-celled, 1-seeded, covered with hooked hairs=Athysanus.

Plants with simple hairs or none; petals white or rose-coloured; fruit orbicular, winged, 1-celled, 1 -seeded $=$ Thysanocarpus.

Glabrous fleshy plants; petals white or purple; fruit elongated, 2-jointed, each joint 1 -celled and 1-seeded, or the lower joint empty $=$ Cakile.

3. Fruit oblong to linear (two to many times as long as broad) .. . . . . . . . . . . 4

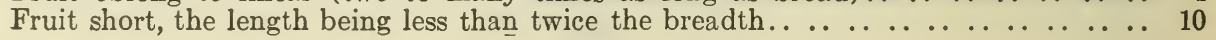


4. Corolla white or purple; fruit linear; embryo pleurorrhizal. . . . . . . . . . . 5

Perennial plants; corolla white, pink, or purple; fruit elliptical or oblong... . . . . 6

Corolla yellow; fruit mostly linear. . . . . . . . . . . . . . . . . . . . . 9

Plants with simple leaves and stellate hairs; corolla white or yellow; fruit elliptical, with 2 rows of seeds; embryo pleurorrhizal=Draba.

5. Perennial plants with scaly rhizomes; leaves palmately divided; seeds in a single row $=$ Dentaria.

Plants with branched hairs; leaves usually simple, often auricled at the base; seeds in 1 or 2 rows, often winged=Arabis.

Leaves simple to pinnatifid; seeds in a single row $=$ Cardamine.

6. Aquatic plants with dissected submerged leaves and simple ærial leaves; fruit elliptical, 1 -celled; seeds in 2 rows $=$ Neobeckia.

Arctic or alpine land plants.. . . . . . . . . . . . . . . . . . . . . 7

7 Tufted plants with pinnatifid leaves and stellate hairs; fruit ovate-lanceolate $=$ Smelowskia.

Leaves simple. . . . . . . . . . . . . . . . . . . . . . . . . . . . . . . 8

$S$ Leaves mostly basal, fleshy, and spatulate, with branched hairs; fruit oblong; embryo notorrhizal=Braya.

Leaves basal; corolla pink or purple; fruit oblong; seeds in 2 rows=Parrya.

Hairs simple or none; fruit oblong-lanceolate, with the septum often perforated; embryo notorrhizal $=$ Eutrema .

9. Leaves mostly pinnatifid; hairs, when present, simple; fruit oblong to linear; seeds mostly in 2 rows; embryo pleurorrhizal=Nasturtium.

Glabrous plants with angular stems and pinnatifid leaves; fruit 4-sided; seeds in 1 row $=$ Campe.

Plants with forked hairs and simple or pinnatifid leaves; hairs on the stem vertical, attached by the middle, appressed; seeds in 1 row=Erysimum.

Hairs on the stem simple or stellate; leaves simple or multifid; seeds in 1 or 2 rows; embryo notorrhizal=Sisymbrium.

10. The septum or partition is narrower than the breadth of the fruit.. ........ 11

The septum is as broad as the fruit............................... 13

11. Corolla white or purplish. . . . . . . . . . . . . . . . . . . 12

Perennial plants with stellate hairs and spatulate leaves; corolla yellow; valves of the fruit inflated, covered with stellate hairs=Physaria.

12. Hairs, when present, simple; petals sometimes absent; fruit mostly orbicular, each cell containing a single seed=Lepidium.

Hairs stellate; fruit elliptical, many-seeded $=$ Hutchinsia.

Glabrous plants with simple leaves, the cauline clasping; fruit orbicular, with two or more seeds in each cell=Thlaspi.

13. Corolla white to purple............................. 14

Plants with stellate hairs and simple leaves; corolla yellow; fruit globose to ellipsoid; style elongated, persistent=Lesqucrella.

14. Aquatic submerged plants with linear leaves in a rosette; fruit elliptical; seeds in 2 rows=Subularia.

Land plants. .................................. . . . . . . . . . . . .

15. Plants glabrous, succulent; fruit globose $=$ Cochlearia...

Annual plants with basal lyrately pinnatifid leaves; fruit suborbicular; seeds in 2 rows, winged=Platyspermum.

\section{Distribution of Genera}

Arabis (Rock-cress) ANESPW. $30 \mathrm{sp.}$

Athysanus pusillus (Round-pod) W. It is an annual plant.

Braya (Arctic Rock-cress) ANW. 3 sp. They are arctic and alpine plants.

Cakile edentula (Sea Rocket) ESW. Annual plants growing on sand on the shores

of the Atlantic, Pacific, and Great Lakes.

Campe americana (Winter-cress) W. It is a biennial, found on wet ground.

Cardamine (Bitter Cress) ANESPW. $17 \mathrm{sp.}$ They occur mostly on wet ground.

Cochlearia (Scurvy-grass) ANEW. $4 \mathrm{sp}$. They are found on northern sea-coasts.

Dentaria (Toothwort) ESW. 4 sp. Two of the species are western and two eastern. In

the latter group two leaves occur on the stem of Two-leaved Toothwort ( $D$. diphylla) while 
Cut-leaved Toothwort (D. laciniata) has three leaves on the stem. All the species occur in woods.

Draba (Whitlow-grass) ANESPW. 30 sp.

Erysimum (Wall-flower) ANEPW. $3 \mathrm{sp}$.

Eutrema (Hole-pod) A. 2 sp.

Hutchinsia procumbens (Spreading Hutchinsia). NIV. It is an annual occurring on moist ground.

Lepidium (Pepper-grass) NESPW. 10 sp.

Lesquerella (Bladder-pod) APW. 4 sp.

Nasturtium (Water-cress) NESPW. 11 sp.

Neobeckia aquatica (River-cress) ES.

Parrya (Naked Cress) A. 3 sp.

Physaria didymocarpa (Double Bladder-pod) PW. A perennial plant occurring in dry situations.

Platyspermum scapigerum (Flat-pod) W. It is an annual species occurring on Vancouver island.

Sisymbrium (Mustard) ANESPW. $16 \mathrm{sp.}$

Smelowskia (Alpine Cress) W. $5 \mathrm{sp.} \mathrm{They} \mathrm{are} \mathrm{perennials} \mathrm{occurring} \mathrm{on} \mathrm{high} \mathrm{mountains.}$ Subularia aquatica (Water Awlwort) EW.

Thlaspi alpestre (Fan-weed) W. It is a perennial, occurring on high mountains.

Thysanocarpus curvipes (Lace-pod) W. An annual, occurring on dry ground. 


\section{CHAPTER XIV}

\section{CHORIPETALOUS DICOTYLEDONS-CISTACEAE, MALVACEAE, ROSACEAE}

\section{CISTACEAE}

1. Shrubby plants with subulate or scale-like imbricated leaves; petals 5 , yellow $=H u d$ sonia.

Herbaceous plants; leaves not imbricated.. . . . . . . . . . . . . . . . . . . 2

2. Petals 5 , yellow, deciduous; style short=Helianthemum.

Freely branching plants with 3 greenish or purplish persistent petals; style absent $=$ Lechea.

\section{Distribution of Genera}

Helianthemum (Frost-weed) ES. 2 sp.

Hudsonia (False Heather) EP. 2 sp. In dry or sandy soil.

Lechea (Pin-weed) ES. 4 sp.

\section{MALVACEAE}

1. There is mostly an involucel of bracts below the calyx; stamens monadelphous.. 2 Flowers without involucels; stamens in a double series=Sidalcea.

2. Bracts of the involucel numerous; anther-bearing region of the staminal column below the summit; ovary 5-celled; fruit a loculicidal capsule $=$ Hibiscus.

Bracts of the involucel 1-3; the column of stamens is anther-bearing at the summit;

ovary 5 -or more-celled; carpels separating from the central axis when ripe.... 3

3. Each flower has 2-3 bracts or sometimes none; each carpel bears a single ovule $=$ Malvastrum.

Each flower has 3 bracts; each carpel bears 2-3 ovules=Sphaeralcea.

\section{Distribution of Genera}

Hibiscus Moscheutos (Rose-mallow) S. It has large rase-coloured flowers and occurs in swamps.

Malvastrum (False Mallow) PW. 2 sp. False Red Mallow (M. coccineum) has stellate hairs, no bracts under the flowers, and is confined to the Prairie.

Sidalcea (Wild Hollyhock) W. 3 sp.

Sphaeralcea rivularis (Globe-mallow) W. It occurs along streams.

\section{ROSACEAE}

This is a somewhat variable family but the general characters are as follows: They are mostly herbs or shrubs but trees may also occur. The leaves are alternate, stipulate, and either simple or compound. The inflorescence may be racemose or cymose and the floral receptacle is usually hollowed so that the flower is more or less perigynous. Flowers aotinomorphic and generally bisexual. There is frequently an epicalyx. Sepals 5, free. Petals 5, free, imbricated in the bud. Stamens bent inwards in the bud, usually numerous, but sometimes equal in number to the petals. The carpels vary in number from 1 to many, are free and usually superior. The fruit may be either dry, when it is generally an achene, or fleshy when it is a drupe, but in many cases the floral receptacle also becomes fleshy and may surround the carpels giving rise to a false fruit or pseudocarp. The seed is without endosperm.

1. Herbs. . . . . . . . . . . . . . . . . . . . . . . . . . . . . . . . . 2

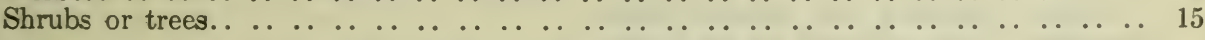

2. Sepals 4 ; petals absent; stamens $1-4$; carpel solitary . . . . . . . . . . . 3

Petals 5 ; stamens 5 ; carpels 5 or more.. . . . . . . . . . . . . . . . 4

Petals usually 5 ; stamens numerous.. $\ldots \ldots \ldots \ldots$ 
3. Leaves palmately lobed or palmately compound; there is an epicalyx of 4 segments $=$ Alchemilla.

Leaves unequally pinnate; flowers in a dense spike; there is no epicalyx; sepals with petaloid tips $=$ Sanguisorba .

4. Leaf composed of 3-5 leaflets; petals yellow=Potentilla sp.

Leaf 2 or more times ternately divided; petals white; stamens opposite the petals= Chamaerrhodos.

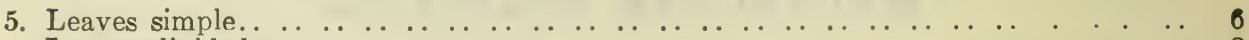

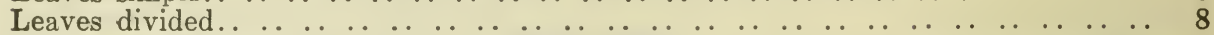

6. Sepals 8-9, petals 8-9; fruit composed of achenes with persistent plumose style $=$ Dryas. Sepals and petals five; fruit composed of drupelets.. . . . . . . . . . . . . . . 7

7. Leaves orbicular, cordate at the base, with crenate margin; the scape-like peduncle bears 1 or 2 white flowers; drupelets nearly dry, enclosed by the calyx=Dalibarda. Leaves palmately lobed; flowers solitary, white; drupelets fieshy $=R u b u s \mathrm{sp}$.

8. Leaves 2-3- times pinnately divided; inflorescence a large panicle; all the flowers on the same plant unisexual; fruit composed of 3 follicles=Aruncus.

Leaves palmately or pinnately divided; flowers mostly bisexual. . . . . . . . . . 9

9. Leaves trifoliolate; fruit fleshy when ripe... . . . . . . . . . . . . . 10

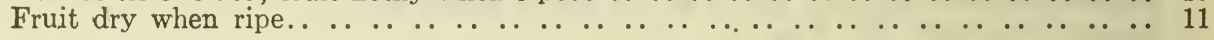

10. Plants with runners; leaves basal; fruit composed of achenes attached to a fleshy receptacle $=$ Fragaria .

There are no runners; cauline leaves present; fruit composed of drupelets $=R u b u s$ sp.

11. Leaves trifoliolate; petals long and narrow; fruit composed of five follicles each of which contains 2-4 seeds=Gillenia.

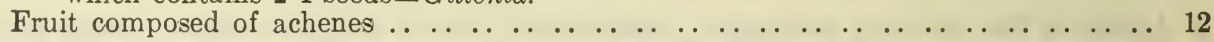

12. Leaves unequally pinnate, some of the segments being smaller than the others; flowers in a long raceme; petals yellow; floral receptacle obconic, covered with hooks when ripe and enclosing 1-2 achenes=Agrimonia.

Flowers not in a raceme; achenes not enclosed in the floral receptacle. . . . . . . . 13

13. Part or the whole of the style is persistent on the fruit; style often jointed or plumose= Geum.

Style deciduous.. . . . . . . . . . . . . . . . . . . . . . . . .

14. Leaves mostly basal with 3 leaflets: petals yellow; carpels $2-6=$ Waldsteinia.

Leaves pinnately or palmately divided; petals yellow, white, or purple; carpels numerous=Potentilla.

15. Fruit dry when ripe............................... 16

Fruit or receptacle fleshy when ripe.. $\ldots \begin{array}{ccccccccccccc} & \ldots & \ldots & \ldots & \ldots & \ldots & \ldots & \ldots & \ldots & \ldots & \ldots & \ldots & 20\end{array}$

16. Fruit composed of achenes. . . . . . . . . . . . . . . . . . . . . . . . . . . . . 17

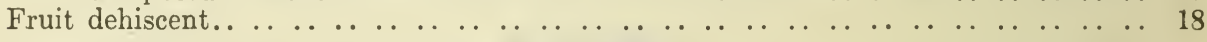

17. Leaves simple, ovate; petals white $=$ Holodiscus.

Leaves simple, cuneate, 3 -cleft at the apex; flowers solitary; petals yellow=Purshia.

Leaves compound; petals white or yellow=Potentilla.

18. Leaves simple. . . . . . . . . . . . . . . . . . . . . . . . . . . . . . . . . . . . . . . . . 19

Leaves twice or thrice ternately divided; flowers in a raceme; fruit dehiscent along both sutures=Luetkea.

19. Bark in layers; leaves palmately lobed; fruits inflated, dehiscing along both sutures $=$ Physocarpus.

Leaves not palmately lobed; fruits not inflated, dehiscing along one suture only= Spiraea.

20. Stem usually prickly; leaves unequally pinnately compound; receptacle urn-shaped, fleshy, enclosing the achenes=Rosa.

Receptacle fleshy, adherent to the carpels. . . . . . . . . . . . . . . . . . . 21

Receptacle not fleshy; the fruit consists of 1 or several drupes.. . . . . . . . . . . 24

21. Leaves simple. . . . . . . . . . . . . . . . . . . . . . . . 22

Leaves unequally pinnately compound=Sorbus. 
22. The cavities of the fruit are twice as many as the styles=Amelanchier.

The cavities of the fruit are equal in number to the styles.. . . . . . . . . . .

23. Carpels leathery or papery when ripe=Pyrus.

Stem usually armed with thorns; carpels bony when ripe=Crataegus.

24. Leaves simple; each flower has a single carpel=Prunus.

Leaves simple, without stipules; flowers in a loose raceme, unisexual; carpels $5=$ Osmaronia.

Stem usually prickly; leaves palmately lobed, or compound, with the stipules adhering to the petiole; carpels numerous=Rubus.

\section{Distribution of Genera}

Agrimonia (Agrimony) ESPW. $4 \mathrm{sp.}$

Alchemilla (Lady's Mantle) ANEW. 5 sp.

Amelanchier (June-berry; Service-berry) NESPW. 8 sp.

Aruncus acuminatus (Goat's Beard) W. It is perennial, occurring in moist woods.

Chamaerhodos Nuttallii (Five-stamened Cinquefoil) P.W.

Crataegus (Hawthorn) ESPW. $26 \mathrm{sp}$. They are mostly eastern but the Black Haw

(C. Douglasii) occurs in the western region.

Dalibarda repens (Dewdrop) E.S. A perennial, occurring in woods.

Dryas (Mountain Avens) ANEW. 4 sp. Chiefly in alpine and arctic situations.

Fragaria (Strawberry) NESPW. 13 sp.

Geum (Avens) ANESPW. $14 \mathrm{sp.} \mathrm{Prairie-smoke} \mathrm{(} G$. ciliatum) has purple petals and iong feathery style and occurs on dry soil.

Gillenia trifoliata (Indian Physic; Bowman's Root) S. It has white or pinkish petals and occurs in woods.

Holodiscus discolor (Ocean Spray) W.

Luetkea pectinata (Partridge-foot) W. It is a low tufted shrub occurring in alpine meadows.

Osmaronia cerasiformis (Indian Plum) W. It has white petals, purplish-black fruits, and occurs in wet soil.

Physocarpus (Ninebark) ESW. 3 sp.

Potentilla (Cinquefoil) ANESPW. $79 \mathrm{sp.}$

Prunus (Cherry; Plum) NESPW. 10sp. The Western Sand-Cherry ( $P$. Besseyi) is a shrub with black fruit. It occurs in Manitoba and is the only species occurring on the prairie.

Purshia tridentata (Antelope-brush) W.

Pyrus (Crab-apple; Chokeberry) ESW. 6 sp. The Black Chokeberry (P. melanocarpa) has a black fruit about one-fourth of an inch in diameter and occurs in wet ground.

Rosa (Rose) ANESPW. $35 \mathrm{sp.}$

Rubus (Bramble) ANESPW. $49 \mathrm{sp.} \mathrm{The} \mathrm{Cloudberry} \mathrm{(} R$. Chamaemorus) is a herbaceous species with palmately lobed leaves and solitary, white, unisexual flowers. It occurs in arctic and alpine situations.

Sanguisorba (Burnet) NEW. $6 \mathrm{sp}$. The only eastern species is Great Burnet (S. canadensis). It grows in wet situations.

Sorbus (Mountain-ash) NEW. 2 sp. The Sharp-leaved Mountain Ash (S. americana) is confined to the eastern region. It occupies damp situations.

Spiraea (Meadow-Sweet; Steeple-bush) ESPW. 9 sp. Of the eastern species the Steeple-bush ( $S$. tomentosa) has the leaves whitish on the under surface, a pyramidal inflorescence and pink flowers. It occurs on wet ground.

Waldsteinia fragarioides (Barren Strawberry) ES. It is a perennial, occurring in woods. 


\section{CHAPTER XV}

\section{CHORIPETALOUS DICOTYLEDONS-FABACEAE, RUTACEAE, VIOLACEAE, SAXIFRAGACEAE}

\section{FABACEAE}

The general characters of this family are as follows. The Canadian species are nearly all herbs with alternate, compound, stipulate leaves. The inflorescence is usually a raceme. The flower is bisexual and zygomorphic. Sepals 5, more or less united. Petals 5, of which the posterior one is the largest and is known as the "standard"; the 2 petals adjacent to the "standard" are known as the "wings", while the other 2 petals are united to form the keel. The stamens are usually 10 in number of which 9 are usually united together while 1 is free. There is a single carpel which is superior in position and gives rise to a legume when ripe. The seed is without endosperm.

There are some exceptional forms. In the genus Amorpha there is only 1 petal, the standard; there are only 5 stamens in Petalostemon; Baptisin and Thermopsis have 10 free stamens; the fruit is an achene in Psoralea, while it is a lomentum in Desmodium and Hedysarum.

1. Shrubs with unequally pinnate leaves and flowers in dense terminal racemes. There is only 1 petal, the standard. All the stamens are united below. Legume short, 1-2seeded=Amorpha.

Herbs. . . . . . . . . . . . . . . . . . . . . . . . . . . . . . . . . . . . . .2

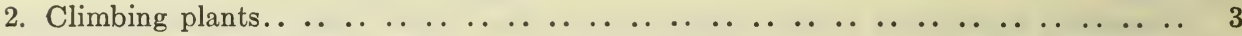

Erect plants, not climbing.

3. Plants climbing by twining spirally... . . . . . . . . . . . . . . . . . . . . 4

Plants climbing by means of tendrils.. . . . . . . . . . . . . . . . . . 7

4. Plants with underground tubers and pinnately compound leaves; stipules deciduous; flowers brownish-purple=Glycine.

Leaves ternately compound.. . . . . . . . . . . . . . . . . . . . . . . . . . . 5

5. Plants with a moniliform row of underground tubers and brownish hairs on the stem; flowers of two kinds, the upper petaliferous and the lower without petals; upper pods long and several-seeded, lower short and mostly 1-seeded=Amphicarpa.

Leaves with stipels and only one kind of flowers and fruits. . . . . . . . . . . 6

6. Flowers in racemes. Keel spirally coiled $=$ Phascolus.

Flowers in heads. Keel incurved=Strophostyles.

7. Style with a tuft of hairs at the top=Vicia.

Style bearded along the inner side=Lathyrus.

8. Leaves palmately compound.. . . . . . . . . . . . . . . . . . . . . . . . . . . . . . . .

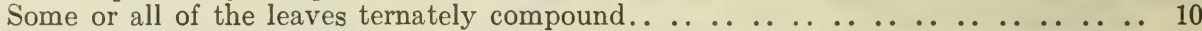

Leaves pinnately compound.. . . . . . . . . . . . . . . . . . . . . . . . . . . . . .

9 Flowers in racemes; stamens all united; fruit a legume with several seeds=Lupinus.

Root tuberous; leaves gland-dotted; flowers in a dense spike; fruit 1-seeded=Psoralea esculenta.

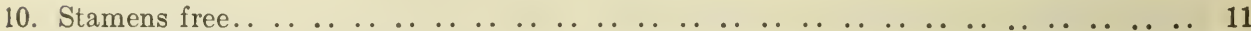

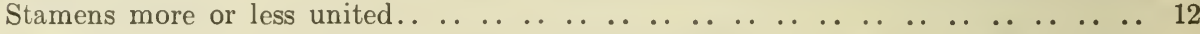

11. Stipules leafy; fruit elongated, curved=Thermopsis.

Stipules small, deciduous; fruit short, stalked, inflated=Baptisia.

12. Fruit ovoid or ellipsoid, often included in the calyx, few-seeded. . . . . . . . . 13

Fruit more or less elongated. . . . . . . . . . . . . . . . . . . . . . . . . . . . . 15

13. Leaves gland-dotted; fruit an achene $=$ Psoralea.

Leaves not gland-dotted. . . . . . . . . . . . . . . . . . . . . . . . . . . . . . . 14 
14. Low tufted plants, densely covered with hairs; stipules scarious; flowers yellowish, sessile in the axils of the leaves; fruit dehiscent=Astragalus triphyllus.

Stipules subulate; flowers frequently of two kinds, some being petaliferous and others apetalous; fruit 1 -seeded, indehiscent, reticulated=Lcspedeza.

Flowers in dense heads or spikes; stipules adnate to the petiole, petals generally persistent; fruits in some species dehiscent=Trifolium.

15. Annual plants with axillary flowers; fruit linear=Hosackia americana.

Perennial plants; leaves provided with stipels; fruit a lomentum =Desmodium.

16. Leaves gland-dotted; flowers in a dense spike; stamens 5 , united into one bundle; fruit enclosed in the calyx, 1-2-seeded=Petalostemon.

Stamens $10 \ldots \ldots \ldots \ldots \ldots \ldots$

17. Flowers in axillary racemes; fruit a lomentum $=$ Hedysarum.

Fruit not transversely jointed. . . . . . . . . . . . . . . . . . . . . . . . . .

18. Roots thick, sweet; leaves gland-dotted; flowers in axillary spikes; fruit indehiscent, covered with hooked prickles=Glycyrrhiza.

Leaves not gland-dotted; fruit not prickly.. . . . . . . . . . . . . . .

19. Stems tufted, very short; keel of the corolla prolonged into a point; fruit short= Oxytropis.

Stems usually elongated; keel not prolonged into a point . . . . . . . . . . . 20

20. Flowers solitary or in umbels; fruit linear=Hosackia.

Flowers in spikes or racemes.. . . . . . . . . . . . . . . . . .

21. Hairy plants with a broad standard; fruit linear, covered with hairs=Tephrosia.

Standard longer than broad; fruit mostly short and inflated, sometimes 2-celled and indehiscent $=$ Astragalus

\section{Distribution of Genera}

Amorpha (Lead-plant; False Indigo) P. 3 sp.

Amphicarpa (Hog-peanut) ES. 2 sp.

Astragalus (Milk-vetch) ANESPW. $49 \mathrm{sp.}$

Baptisia (Wild Indigo) S. 2 sp. In Yellow Indigo (B. tinctoria) the flowers are yellow while in White Indigo (B. leucantha) they are white.

Desmodium (Tick-trefoil) ESP. $15 \mathrm{sp.} \mathrm{Only} \mathrm{one} \mathrm{species,} \mathrm{Showy} \mathrm{Tick-trefoil} \mathrm{(} D$. canadense) extends as far west as Manitoba.

Glycine Apios (Groundnut) ES. It occurs in moist ground.

Glycyrrhiza lepidota (Wild Licorice) NEPW.

Hedysarum (Sweet Broom) ANEPW. $5 \mathrm{sp}$. The Northern Sweet Broom ( $H$. boreale) is the only eastern species. It occurs in rocky places.

Hosackia (Bird's Foot Trefoil) W. 8 sp.

Lathyrus (Vetchling) ANESPW. $7 \mathrm{sp}$. The only species found on the prairie is the Veined Pea ( $L$. venosus). It has purple flowers and occurs in wet places.

Lespedeza (Bush-clover) S. 5 sp

Lupinus (Lupin) ANSPW. $28 \mathrm{sp}$. The majority of the species are western but Wild Lupin (L. perennis) with blue flowers occurs in southern Ontario on sandy soil.

Oxytropis (Loco-weed) ANEPW. $24 \mathrm{sp}$. The only eastern species is Yellow Loco-weed

(O. campestris) with flowers of various colours. It occurs in rocky places.

Petalostemon (Prairie-clover) P. 4 sp.

Phaseolus polystachyus (Wild Bean) S. It occurs among bushes.

Psoralea (Bread-root) SPW. $5 \mathrm{sp}$. The only species east of the prairie is Sainfoin Breadroot ( $P$. Onobrychis) which occurs on river-banks in southern Ontario.

Strophostyles helvola (Trailing Wild Bean) ES. It has a greenish-purple corolla and occurs on sandy soil.

Tephrosia virginiana (Goat's Rue) ES. It has yellowish-purple flowers and occurs on dry sandy soil.

Thermopsis (Prairie-bean) P. 2 sp.

Trifolium (Olover) SW. $14 \mathrm{sp.} \mathrm{All} \mathrm{of} \mathrm{the} \mathrm{species} \mathrm{are} \mathrm{western} \mathrm{except} \mathrm{Buffalo-clover}$ (T. reflexum). It has a red standard, white wings and keel, and occurs in meadows in southern Ontario.

Vicia (Vetch) ESPW. 8 sp. The Pale Vetch ( $V$. carolinima) with nearly white flowers is confined to southern Ontario and occurs on river-banks. 


\section{RUTACEAE} xylum.

Stem prickly. leaves pinnately compound; carpels separate; fruit dehiscent $=$ Xantho-

Stem not prickly; leaves ternately compound; carpels united; fruit winged and indehiscent $=$ Ptelea.

\section{Distribution of Genera}

Ptelea trifoliata (Hop-tree) S. Both leaves and flowers have a disagreeable odour.

Xanthoxylum americanum (Prickly Ash) ES. The yellowish-green flowers appear before the leaves.

\section{VIOLACEAE}

Flowers usually of two kinds, petaliferous and apetalous; sepals prolonged at the base; 1 of the petals is prolonged into a spur; 2 of the stamens are provided with appendages and the anthers are connivent $=$ Viola.

Sepals not prolonged at the base; one of the petals is broader than the others and is saccate; stamens united into a sheath with a bilobed gland at the base $=H$ Hbanthus.

\section{Distribution of Genera}

Hybanthus concolor (Green Violet) S. It occurs in moist woods.

Viola (Violet) ANESPW. $46 \mathrm{sp.}$

\section{SAXIFRAGACEAE}

The Canadian members of this family are mostly herbs with alternate, simple, exstipulate leaves. The commonest type of inflorescence is the cyme, but the raceme is also found. The flower is usually perigynous and bisexual. The sepals and petals are usually 5 in number and actinomorphic. Stamens generally 5 or 10 in number. Carpels usually fewer than the petals and united below, often 2 in number. The fruit is usually a capsule. Exceptions to the above general characters will be found in connection with the various genera.

1. Shrubs.. . . . . . . . . . . . . . . . . . . . . . . . . . . . . . 2

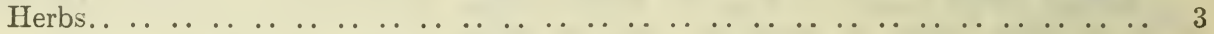

2. Leaves opposite; sepals and petals 4 ; stamens numerous; fruit a capsule $=$ Philadelphus. Leaves alternate, palmately veined; stamens 5 ; ovary inferior, 1 celled; fruit a berry $=$ Ribes.

3. Perennial herbs with solitary flowers on a long scapoid peduncle which frequently bears a single leaf; corolla white or pale-yellow; stamens 5 , with 5 alternating bundles of gland-tipped staminodes; carpels 3-4; fruit a 1-celled capsule=Parnassia.

Stamens 4-10; staminodles absent. . . . . . . . . . . . . . . . . . . . . . . . . . 4

4. Sepals 4-5. petals absent; stamens 4 or 8; fruit a 1-celled capsule $=$ Chrysosplenium.

Petals present; stamens 3,5 , or $10 . . \ldots \ldots \ldots \ldots \ldots \ldots \ldots \ldots \ldots \ldots \ldots \ldots \ldots$

5. Petals 4, persistent; stamens 3; ovary one-celled $=$ Tolmiea.

Petals 5 ; stamens 5 or $10 \ldots \ldots \ldots \ldots \ldots \ldots \ldots$

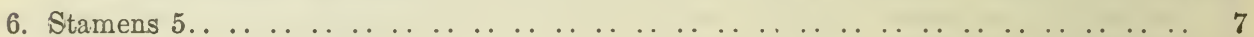

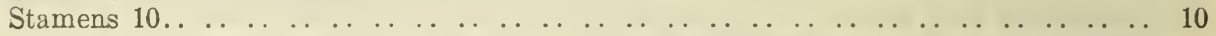

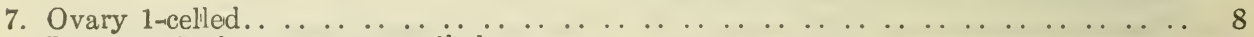

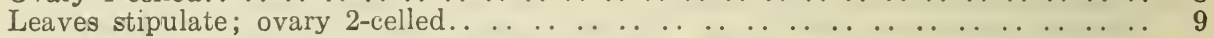

8. Flowers in a simple raceme; petals deeply lobed=Mitella sp.

Leaves with dilated bases resembling stipules; flowers in small cymose clusters which are grouped in a panicle=Heuchera.

9. Rhizome short, bearing bulblets; basal leaves ternately divided; flowers in a compact cyme; ovary almost inferior $=$ Suksdorfia.

Rhizome not bearing bulblets; basal leaves reniform in outline, mostly cleft into 5-7 lobes; flowers in panicles on leafy lateral shoots; ovary half-inferior=Therophon.

10. Ovary 1-celled.. . . . . . . . . . . . . . . . . . . . . . . . . . . . . . . . . . 11

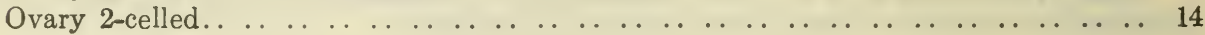




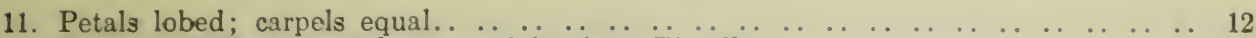
Petals undivided; carpels unequal in size $=$ Tiarella.

12. Rhizome bearing bulblets; carpels $3=$ Lithophragma.

Rhizome scaly; carpels $2 . \ldots \ldots \ldots \ldots \ldots \ldots$

13. Receptacle more or less urn-shaped; capsule beaked=Tellima.

Receptacle saucer-shaped; capsule not beaked=Mitella sp.

14. Leaves basal or alternate; flowers usually in a cyme and white or yellow in colour= Saxifraga.

Leaves mostly opposite; flowers solitary, purple in colour=Antiphylla.

\section{Distribution of Genera}

Antiphylla (Purple Saxifrage) ANEW. $2 \mathrm{sp.}$

Chrysosplenium (Golden Saxifrage) ANESPW. 3 sp. The only species in Eastern Canada is Eastern Golden Saxifrage (C. americanum) which grows in wet, shaded places. The lower leaves are opposite.

Heuchera (Alum-root) ESPW. 13 sp.

Lithophragma (Prairie-star) W. 3 sp.

Mitella (Mitrewort) NESW. $7 \mathrm{sp}$. There are two eastern species both of which occur in woods, namely, Two-leaved Mitrewort ( $M$. diphylla) with basal ovate leaves and only 2 leaves on the stem and Naked Mitrewort ( $M$. nuda) with reniform basal leaves and only 1 leaf on the stem or none.

Parnassia (Grass of Parnassus) ANESPW. $6 \mathrm{sp.} \mathrm{They} \mathrm{occur} \mathrm{in} \mathrm{wet} \mathrm{places.}$

Philadelphus (Mock-orange) W. 2 sp. Flowers white and showy.

Ribes (Currant; Gooseberry) NESPW. 20 sp. Golden Currant (R. aureum) with smooth branches and bright-yellow flowers is confined to the prairie.

Saxifraga (Saxifrage) ANESPW. 55 sp. Many are alpine plants. tains.

Suksdorfia ranunculifolia (Bulbous Saxifrage) W. It occurs on wet rocks in the moun-

Tellima (Fringe-cup) W. 3 sp.

Therophon (Kidney-saxifrage) AW. $5 \mathrm{sp.}$

Tiarella (Coolwort) ESW. 4 sp. The only eastern species is Foamflower (T. cordifolia) which occurs in woods.

Tolmiea Menziesii (Youth-on-age) W. It occurs in woods. It reproduces vegetatively by the formation of a bud at the top of the petiole. 


\section{CHAPTER XVI}

\section{CHORIPETALOUS DICOTYLEDONS-CACTACEAE, OENOTHERACEAE, ARALIACEAE, UMBELLIFERAE}

\section{CACTACEAE}

1. Stem globose; leaves absent; flowers purple or yellow=Mammillaria.

Stem composed of more or less flattened joints; leaves awl-shaped, falling off at an early period; flowers yellow=Opuntia.

\section{Distribution of Genera}

Mammillaria (Ball-cactus) P. 2 sp. Yellow Ball-cactus ( $M$. missouriensis) has yellow flowers and scarlet berries, while Purple Cactus ( $M$. vivipara) has purple flowers and green berries.

Opuntia (Prickly Pear) SPW. 3 sp. One species, namely, Devil's Tongue (O. humifusa) with smooth, edible fruit is confined to southern Ontario.

\section{OENOTHERACEAE}

The plants of this family are herbs, with simple, mostly alternate, exstipulate leaves. Flowers commonly in racemes, or axillary, actinomorphic, and bisexual. The flower is typically arranged on the plan of four, with two whorls of stamens. The petals are convolute in the bud. The ovary is inferior and 4-celled; the fruit is usually a capsule but is sometimes indehiscent. Exceptional forms are mentioned below.

1. Plants with rhizomes and opposite leaves; there are 2 sepals, 2 petals, 2 stamens, and 2 carpels; the fruit is indehiscent and is covered with hooked bristles=Circaea.

Sepals 4 ; stamens 4 or 8 ; fruit not covered with hooks.. . . . . . . . . . 2

2. Flowers axillary; stamens $4 \ldots \ldots \ldots \ldots \ldots$

Stamens 8, all perfect, or 4 perfect stamens and 4 staminodes.. $\ldots \ldots \ldots \ldots \ldots \ldots$

3. Leaves opposite; petals usually absent=Isnardia.

Leaves alternate; petals present=Ludwigia.

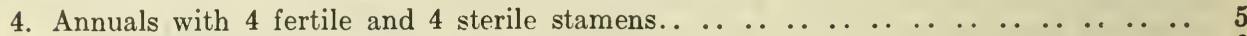

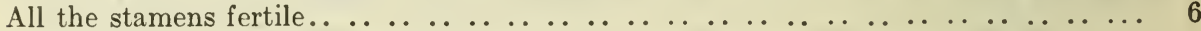

5. Flowers axillary, minute; petals entire; ovary 2-celled=Gayophytum.

Flowers showy, in a terminal raceme; petals 3-lobed; ovary 4-celled=Clarkia pulchella.

6. Fruit short, ribbed, indehiscent, 1-4-seeded=Gaura.

Fruit dehiscent.. . . . . . . . . . . . . . . . . . . . . . . . . . . . . .

7. Leaves alternate or opposite; seeds provided with a tuft of hairs=Epilobium.

Leaves alternate; seeds without hairs. . . . . . . . . . . . . . . . . . . . . 8

8. Annual plants with the flowers in a terminal raceme; petals purple; anthers attached neär the base and erect=Clarkia rhomboidea.

Flowers usually in spikes or axillary; anthers attached near the middle and versatile $=$ Oenothera.

\section{Distribution of Genera}

Circaea (Enchanter's Nightshade) NESW. $4 \mathrm{sp}$. They have white flowers and occur in woods.

Clarkia (Pink Fairies) W. 2 sp.

Epilobium (Willow-herb) ANESPW. $36 \mathrm{sp.} \mathrm{Yellow} \mathrm{Willow-herb} \mathrm{(E.} \mathrm{luteum)} \mathrm{is} \mathrm{a}$ western species occurring along mountain streams, easily distinguished by the yellow colour of the flowers.

Gaura (Butterfly-weed) ESP. $2 \mathrm{sp}$. The Scarlet Butterfly-weed ( $G$. coccinea) is confined to the prairie while the Pink Butterfly-weed ( $G$. biennis) is eastern and occurs on dry soil. 
Gayophytum ramosissimum (Baby's Breath) W. It is extensively branched, has flowers about $\frac{1}{8}$ of an inch in diameter and occurs on dry soil.

Isnardia palustris (Marsh Purslane) ESPW. It occurs in swamps.

Ludwigia (Seed-box) S. $2 \mathrm{sp}$. The Many-fruited Seed-box (L. polycarpa) has sessile greenish flowers about $\frac{1}{8}$ of an inch broad while Yellow Seed-box (L.alternifolia) has stalked yellow flowers about $\frac{1}{2}$ inch broad. Both species occur in swamps.

Oenothera (Evening Primrose) NESPW. $26 \mathrm{sp}$. Some of the species have very short stems, pink flowers and angular fruits.

\section{ARALIACEAE}

1. Shrubs with prickly stems and palmately lobed leaves; styles 2; fruit scarlet $=$ Echinopanax.

Herbs, with compound leaves.........................

2. Leaves alternate; styles 5 ; fruit black $=$ Aralia .

Leaves in whorls of 3 , palmately compound; styles $2-3$; fruit yellow or red $=$ Panax.

\section{Distribution of Genera}

Aralia (Sarsaparilla) NESW. $3 \mathrm{sp.} \mathrm{American} \mathrm{Spikenard} \mathrm{(A.} \mathrm{racemosa)} \mathrm{has} \mathrm{an} \mathrm{erect}$ profusely branched stem with numerous umbels; in Wild Sarsaparilla (A. nudicaulis) the stem is prostrate and the scape bears usually three umbels; Bristly Sarsaparilla (A. hispida) has an erect stem covered with bristles near the base and with several terminal umbels. All the three species occur in woods.

Echinopanax horridum (Devil's Club) W. It occurs in wet woods.

I'nnax (Ginseng) ES. 2 sp. American Ginseng ( $P$. quinquefolium) has fleshy spindleshaped aromatic roots, 5 leaflets and bright-red fruit; considerable quantities of the roots are exported to China. Dwarf Giseng $(P$. trifolium $)$ has a globular tuber, 3-5 leaflets, and yellowish fruit. Both the above species occur in woods.

\section{UMBELLIFERAE}

The Canadian species of this family are all herbs, with hollow internodes in the stem, and alternate, exstipulate, divided leaves with sheathing leaf-bases. The inflorescence is commonly a compound umbel and both the compound and the simple umbels composing it may have an involucre of bracts at the base. The flower is usually actinomorphic and bisexual with 5 sepals, 5 petals, 5 stamens and 2 carpels. The sepals are usually united with the ovary and are visible only as small pointed projections. The petals are mostly white or yellow in colour, with an inflexed tip and those on the outer side of the umbel are frequently of larger size than the others in the same flower. The ovary is inferior and two-celled, with a single pendulous ovule in each cell; the base of each of the two styles is expanded to form a honey-secreting disk known as the stylopodium. The fruit is a schizocarp which splits when ripe into two mericarps loosely attached to the summit of a prolongation of the axis known as the carpophore; the inner surface of each mericarp is known as the commissural surface while the outer or dorsal surface usually bears 5 ribs or ridges known as the primary ribs with sometimes the addition of 4 secondary ribs between them. Running beneath the furrows and on the commissural surface the canals called vittae, containing an aromatic oil, are frequently found. The seed is usually firmly attached to the pericarp; the embryo is small and the endosperm is cartilaginous in texture.

A few exceptions to the above characters may be noted. The leaves are simple in Bupleurum, Hydrocotyle and Lilaeopsis; the flowers are grouped in heads in Eryngium; in Hydrocotyle and Lilaeopsis simple umbels are found; in Sanicula the arrangement of the umbels is more or less irregular; some of the flowers in Sanicula contain stamens only. Other peculiarities will be mentioned under the genera. As a rule ripe fruits are necessary for the identification of members of this family.

1. Perennial plants, with simple leaves.. . . . . . . . . . . . . . . . . . . . . 2

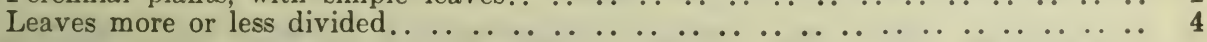

2. Lower leaves linear-lanceolate, with parallel veins; stem leaves clasping; flowers yellow = Bupleurum.

Creeping plants with white flowers in simple umbels.. ... .........

3. Leaves reduced to linear, hollow, transversely jointed petioles = Lilaeopsis.

Leaves orbicular or reniform, sometimes peltate, with long petioles = Hydrocotyle.

4. Upper leaves opposite; flowers in dense heads with spiny-toothed bracts; sepals welldeveloped; fruit covered with scales or tubercles = Eryngium.

Flowers in umbels, with or without bracts.. $\ldots \ldots \ldots \ldots \ldots$ 
5. Fruit covered with hooks or bristles. . . . . . . . . . . . . . . . . . . . . 6

Fruit smooth or ribbed, not bristly.. . . . . . . . . . . . . . . . . . . . . . .

6. Annual plants with pinnately divided leaves; flowers white.... . . . . . . . . 7

Perennial plants with palmately compound or ternately divided leaves; umbels with few rays or irregularly grouped.. . . . . . . . . . . . . . . . . . . . . $\quad . \quad 8$

7. Calyx-teeth and stylopodium obsolete; prickles with several barbs at the tip = Daucus. Calyx-teeth prominent; stylopodium conical; prickles with a single hook = Caucalis.

8. Plants with aromatic roots; flowers white or purplish; flowers on elongated pedicels; fruit linear-clavate with stout appressed bristles on the ribs $=$ Osmorrhiza.

Umbels irregularly compound; flowers greenish-yellow or purplish, on short pedicels; fruit globular, without ribs, covered with hooked bristles = Sanicula.

9. Fruit more than twice as long as wide... . . . . . . . . . . . . . . . . . . . . . 10

Length of fruit less than twice the width. . . . . . . . . . . . . . . . . . . . 11

10. Annual plants, somewhat hairy with an involucel of numerous bracts $=$ Chaerophyllum. Perennial glabrous plants with aromatic roots, ternately compound leaves and an involucel of bracts=Ligusticum scoticum.

Perennial glabrous plants with ternately compound leaves, irregular umbels and no involucel $=$ Cryptotaenia.

11. Mericarps flattened, with winged margins or winged ribs. . . . . . . . . . . . . 12

Mericarps not flattened.. . . . . . . . . . . . . . . . . . . . . . . . . . . . . . .

12. Plants with thick roots and very short stems; bracts of the involucel foliaceous; dorsal ribs of the fruit winged $=$ Cymopterus.

Dorsal ribs of the fruit not winged..

13. Plants with fusiform or tuberous roots; leaf-bearing stem short, not rising much above the ground level; flowers yellow, white, or purple... . . . . . . . . . . 14

Leafy stem usually tall and stout; flowers usually white.. . . . . . . . . . . . 15

14. Involucral bracts sometimes present; flowers yellow or purple; marginal wings of the mericarps thick and corky=Leptotaenia.

Involucral bracts absent; flowers yellow, white or purple; marginal wings of the mericarps thin, not corky=Lomatium.

15. Plants with clustered tuberous roots; leaves once pinnate; leaflets linear-lanceolate= Oxypolis.

Leaves ternately or pinnately compound. . . . . . . . . . . . . . . . . . 16

16. Stout woolly perennials, with broad leaf-segments; dorsal ribs of the fruit scarcely evident; oil-canals extending only half way down the fruit=Heracleum.

Stem mostly glabrous; dorsal ribs of fruit prominent; oil-canals extending almost to the base of the fruit.......................................... 17

17. Ultimate segments of the leaves small and narrow=Conioselinum.

Ultimate segments of the leaves broad=Angelica.

18. Flowers yellow . . . . . . . . . . . . . . . . . . . . . . . . . . . . . 19

Flowers white. . . . . . . . . . . . . . . . . . . . . . . . . . . . . . . . . . . .

19. Resiniferous plants with thick roots and short dichotomously branched stems; leaves pinnately divided, with narrow segments; bracts of the involucel few and narrow $=$ Musineon.

Leaves ternately compound, with broad segments. . . . . . . . . . . . . . . 20

20. Stem hairy at the nodes; bracts of the involucel small; ribs of the fruit winged= Thaspium.

Stem glabrous; ribs of the fruit not winged.. . . . . . . . . . . . . . . . 21

21. Leaf-segments entire; there is no involucel; ribs of the fruit feebly developed= Tonidia.

Leaf-segments serrate or crenate; there is an involucel of small bracts; the central flower of each simple umbel is sessile; ribs of the fruit prominent=Zizia.

22. All or most of the leaves once pinnate; there is an involucre of several bracts usually

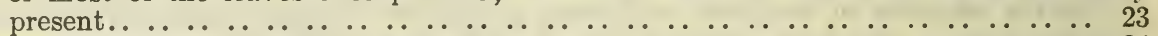

Leaves ternately or pinnately divided.. . . . . . . . . . . . . . . . . . . . . . 24

23. Leaflets mostly ovate; fruit globose with indistinct ribs=Berula.

Leaflets linear, 7-17 in number; fruit somewhat flattened, with prominent ribs $=$ Sium. 
Roots clustered, fusiform; leaflets linear, 3-11 in number; fruit somewhat flattened =Carum.

24. Short-stemmed glabrous plants with an underground tuber and leaves ternately divided; a similar leaf forms the involucre below the umbel which consists of 1-4 rays; fruit broader than long=Erigenia.

Involucre, if present, composed of simple bracts; fruit as long as broad, or longer than broad.. . . . . . . . . . . . . . . . . . . . . . . . . . . . . . . . 25

25. Short-stemmed villous plants with rather fleshy leaflets; fruit globose, with winged ribs =Glehnia.

Stem and leaves glabrous; fruit somewhat flattened; ribs not winged.. . . . . . 26

26. Leaves twice to thrice ternate with large inflated petioles; inflorescence puberulent; flowers greenish-white; calyx teeth obsolete; stylopodium flat; ribs prominent, hollow; oil-tubes solitary in the intervals=Coelopleurum.

Ribs of the fruit not hollow............................ . . . 27

27. Plants with aromatic roots and leaves ternately compound or ternate-pinnately compound; calyx teeth small or obsolete; stylopodium conical; fruit nearly round in transverse section; there are 3-5 oil-tubes in the intervals=Ligusticum.

Leaves mostly pinnately divided; calyx-teeth distinct; oil-tubes solitary in the inter-

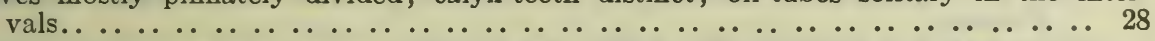

28. Roots or underground stems often thick and fleshy; leaves pinnately compound; stylopodium conical; fruit flat in transverse section $=$ Cicuta.

Leaves ternate, then bipinnate; stylopodium flat or wanting; fruit round in transverse section=Oenanthe.

\section{Distribution of Genera}

Angelica (Angelica) NESW. 6 sp. The only eastern species is Purple-stemmed Angelica.

(A. atropurpurea). It has glabrous umbels and grows on wet ground.

Berula erecta (Water-parsnip) EW. It occurs in swamps and streams.

Bupleurum americanum (Thorough-wax) AW. It occurs only on mountains.

Carum (Caraway) PW. 3 sp. Yamp (C. Gairdneri) has edible roots.

Caucalis microcarpa (Hedge-parsley) W.

Chaerophyllum procumbens (Chervil) S. It occurs in moist ground.

Cicuta (Water-hemlock) NESPW. 6 sp. In Bulb-bearing water-hemlock (C. bulbifera)

the upper leaves have small bulblets in their axils. All the species occur in swamps.

Coelopleurum (Sea-angelica) ANEW. 2 sp. Both species are confined to the sea-coast, the Eastern Sea-angelica (C. actoeifolium) occurring on the Atlantic side and Western Seaangelica ( $C$. longipes) being found on the Pacific side of the continent.

Conioselinum (Hemlock-parsley) ANESW. $5 \mathrm{sp}$.

Cryptotaenia canadensis (Honewort) ES. It occurs in woods.

Cymopterus (Dwarf-parsley) PW. $2 \mathrm{sp}$.

Daucus pusillus (Western Wild Carrot) W. It occurs in dry soil.

Erigenia bulbosa (Harbinger of Spring) S. It occurs in deciduous woods.

Eryngium articulatum (Eryngo) W. It occurs in wet places.

Glehnia littoralis (Shore-glehnia) W. It is found on drifting sand on the Pacific coast.

Heracleum lanatum (Cow-parsnip) NESW. It occurs in wet ground.

Hydrocotyle (Marsh-pennywort) EW. $4 \mathrm{sp}$. Of the two eastern species the Roundleaved Marsh-pennywort ( $H$. umbellata) has peltate leaves. All the species grow in wet places.

Leptotaenia (Wild Parsnip) W. 3 sp. Mountain Wild Parsnip (L. multifida) has yellow flowers. The other two species have purple flowers.

Ligusticum (Lovage) ANEW. 4 sp. Scottish Lovage (L. scoticum) occurs on both the Atlantic and Pacific coasts and is the only species found in the East.

Lilaeopsis (Lilaeopsis) EW. 2 sp. Eastern Lilaeopsis ( $L$. linata) occurs in salt marshes and is confined to the East while Western Lilæopsis ( $L$. occidentalis) occurs only in the West.

Lomatium (Prairie-parsley; Biscuit-root) PW. $15 \mathrm{sp.}$

Musineon (Forked-parsley) PW. $3 \mathrm{sp}$.

Oenanthe sarmentosa (Water-celery) W. It occurs in wet ground.

Osmorrhiza (Sweet Cicely) NESPW. 9 sp.

Oxypolis rigidior (Cowbane) S. It occurs in swamps.

Sanicula (Snake-root; Sanicle) ESPW. $10 \mathrm{sp.}$

Sium cicutaefolium (Water-parsnip) NESW. It occurs in swamps.

Taenidia integerrima (Yellow Pimpernel) ES. It occurs in dry gravelly woods.

Thaspium barbinode (Meadow-parsnip) SPW. It ocurs on the banks of streams.

Zizia (Alexanders) ESP. 2 sp. In Heart-leaved Alexanders (Z. cordata) the basal leaves are simple and cordate, while in Early Meadow-parsnip (Z. aurea) the basal leaves are ternately compound. 


\section{SYMPETALOUS DICOTYLEDONS-FAMILIES AND GENERA}

1. Shrubs or trees.. . . . . . . . . . . . . . . . . . . . . . . . . . . . . . .

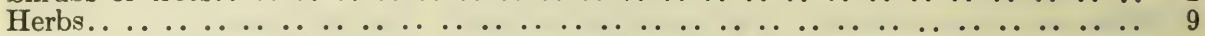

2. Leaves opposite or whorled.. . . . . . . . . . . . . . . . . . . . . . . . 3

Leaves alternate.. . . . . . . . . . . . . . . . . . . . . . . . . . . . . . 6

3. Shrubs with flowers in dense heads; stamens $4=$ Cephalanthus.

Shrubs climbing by means of rootlets on the stem; corolla scarlet; stamens 4; seeds winged $=$ Tecoma.

Flowers not in heads; stamens 2 or more than $4 \ldots \ldots \ldots \ldots \ldots \ldots$

4. Trees with pinnately compound leaves; stamens 2 ; fruit dry, winged, indehiscent $=$ Fraxinus.

Shrubs with 5 -10 stamens; fruit fleshy or a capsule.. . . . . . . . . . . . . 5

5. Stamens 5 ; ovary inferior; fruit fleshy=CAPRIFOLIACEAE (p. 70).

Stamens 5-10; ovary superior; fruit a capsule=ERICACEAE (p. 57).

6. Flowers in heads; anthers united; fruit 1-seeded=COMPOSITAE (p. 73).

Flowers not in heads; anthers free; fruit several-seeded. . . . . . . . . . . . 7

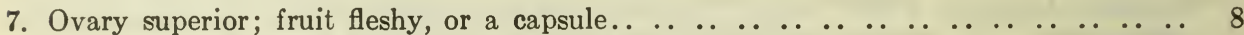

Ovary inferior; fruit fleshy=VACCINIACEAE (p. 59).

8. Flowers solitary; stamens 5 ; ovary 3 -celled=Diapensia.

Flowers clustered; rarely solitary; stamens 8 to 10 ; ovary 4-5-celled=ERICACEAE (p. 57).

9 Parasitic or saprophytic plants without chlorophyll.. ... . . . . . . . . . 10

Plants green, or with some chlorophyll. . . . . . . . . . . . . . . . . 12

10. Twining plants, attached to the stems of other plants; flowers in cymose clusters; capsule 1 -4-seeded $=$ Cuscuta.

Plants growing out of the soil or attached to the roots of other plants; flowers mostly in spikes or racemes; capsule many-seeded................... 11

11. Corolla actinomorphic, with petals free or united; stamens $6-10$; ovary $4-5$-celled= MONOTROPACEAE (p. 57).

Flowers all alike, grouped all round the axis of the raceme, actinomorphic, with free pink petals; stamens 10 ; ovary $4-5$-celled $=$ Pyrola aphylla.

Corolla bilabiate; stamens 4 ; ovary one-celled=OROBANCHACEAE (p. 66).

12. Flowers in heads or $\mathrm{n}$. prarent heads.. . . . . . . . . . . . . . . . 13

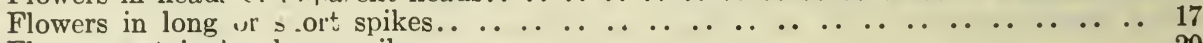

Flowers not in heads of spikes..

13. Flowers in true heads with an involucre of bracts; stamens 5 with anthers generally united; styles 2; ovary inf rior; fruit 1 -seeded and indehiscent=COMPOSITAE

(p. 73).
Flowers opening in irregular order, in apparent heads; anthers free; styles 2-5; ovary usually superior............................... 14

14. Leaves ternately compound, mostly basal, with a single pair of opposite leaves on the flowering stem; flowers small and greenish; fruit fleshy, with several seeds $=$ Adoxa. Leaves simple or pinnately divided; flowers brightly coloured; fruit not fleshy.. 15

15. Leaves opposite; corolla bilabiate; stamens 2 or 4 ; fruit a schizocarp=IABAATAE (p. 65).

Leaves basal or aitrrnate; corolla actinomorphic; stamens 5 ; fruit indehiscent or a capsule.................................. . . . 16

16. Petals almost separate; stigmas 5 ; fruit 1 -seeded and indehiscent $=$ Statice.

Petals united into a long tube; stigmas 3 ; fruit a capsule=POLEMONIACEAE ( $p .64$ ). 
17. Leaves all basal; flowers wind-pollinated, actinomorphic; stamens 4; fruit a lid-capsule $=$ Plantago.

Leaves alternate, flowers bluish, zygomorphic; stamens 2 ; fruit separating into 2 nutlets=Lagotis.

Leaves usually opposite; flowers brightly coloured, zygomorphic. . . . . . . . . 18

1S. Stamens 2; ovary 2-celled; fruit a loculicidal capsule with 4 seeds=Dianthera.

Stamens 4. . . . . . . . . . . . . . . . . . . . . . . . . . . . 19

19. Ovary 1-celled, containing a single ovule; fruit an achene, enclosed by the calyx which has 3 of the teeth hooked=Phryma.

Ovary 2-4-celled with an ovule in each cell; fruit separating into $2-4$ segments= VERBBENACEAE (p. 66).

Ovary 2-celled; fruit a loculicidal capsule with many seeds=SCROPHULARIACEAE (p. 67).

20. Ovary inferior. $\ldots \ldots \ldots \ldots \ldots \ldots \ldots$

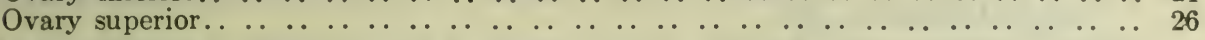

21. Plants climbing by means of tendrils; leaves palmately veined; flowers unisexual= CUCURBITACEAE (p. 71).

Plants not climbing. . . . . . . . . . . . . . . . . . . . . . . . . . . 22

22. Plants frequently with milky juice; leaves basal or alternate...........23

Milky juice absent; leaves opposite. . . . . . . . . . . . . . . . . . . . 24

23. Corolla actinomorphic; anthers free=CAMPANULACEAE (p. 71).

Corolla zygomorphic, frequently split down one side; anthers united into a tube= LOBELIACEAE (p. 71).

24. Stamens 3; fruit 1-seeded and indehiscent=VALERIANACEAE (p. 72).

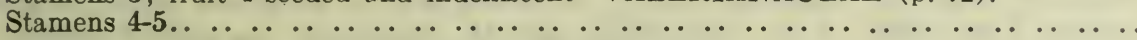

25. Leaves stipulate or in apparent whorls=RUBIACEAE $(p, 70)$.

Leaves not stipulate=CAPRIFOLIACEAE (p. 70).

26. Corolla zygomorphic.. . . . . . . . . . . . . . . . . . . . . 27

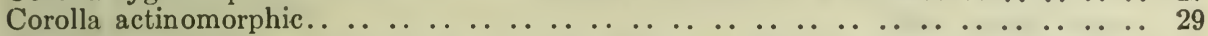

27. Leaves basal or alternate; flowers solitary or in a raceme; corolla spurred; stamens 2 ; fruit a capsule=LENTIBULARIACEAE ( .67$)$.

Corolla very rarely spurred, stamens $2-4 \ldots \ldots \ldots$

28. Stems mostly 4-sided; leaves opposite and usually scented; flowers usually in clustered cymes in the axils of the leaves; corolla bilabiate; stamens 2 or 4 ; fruit splitting into 4 one-seeded segments=LABIATAE (p. 65).

Leaves opposite or alternate; flowers solitary or in racemes, or branched cymes; fruit a capsule $=$ SCROPHULARIACEAE (p. 67).

29. Plants with milky juice........... . . . . . . . . . . . . 30

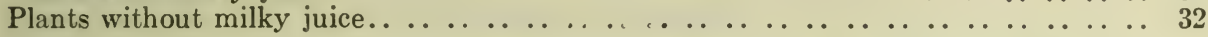

30. Leaves mostly opposite; carpels separate; fruit composed of follicles; seed with a tuft of hairs.. . . . . . . . . . . . . . . . . . . . . . . . . . . . . 31 Plants frequently twining; leaves alternate; carpels united; fruit a capsule $=$ CON $\ddot{\text { VOLL- }}$ VULACEAE (p. 61).

31. Anthers with appendages; pollen-grains united into masses (pollinia)=ASCLEPIADACAE (p. 62).

Anthers without appendages; pollen-grains separate=Apocynum.

32. Leaves basal, linear; flowers mostly solitary, unisexual, inconspicuous; stamens 4; fruit 1 -seeded and indehiscent=Littorella.

Flowers very seldom solitary, bisexual; stamens nearly always $5-10$; fruit usually containing 4 or more sceds.. . . . . . . . . . . . . . . . . . . . 33

33. Stamens directly in front of the lobes of the corolla; ovary 1-celled, with basal or free-central placentation.. . . . . . . . . . . . . . . . . . . . . . . . . . . . . . . 34 Stamens alternating with the lobes of the corolla or twice their number; ovary $1-3-$ celled.. . . . . . . . . . . . . . . . . . . . . . . . . . . . . . . . . . 35

34. Style single; fruit a capsule, with several seeds=PRIMULACEAE (p. 59).

Petals separate almost to the base; styles 5; fruit 1-seeded and indehiscent=Limonium. 
35. Stamens 8 or 10 ; carpels 4 or $5=$ PYROLACEAE (p. 57).

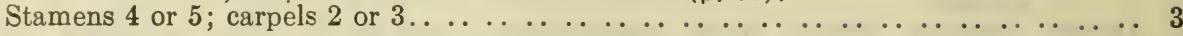

36. Inflorescence usually coiled like a watch-spring; ovary 4-lobed, with the style springing from the centre of the lobes; fruit splitting into 4 one-seeded segments=BORAGINACEAE (p. 62).

Style terminal; fruit a capsule or a berry . . . . . . . . . . . . . . . . . . . . . . 37

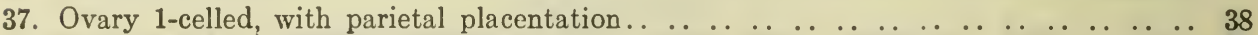

Ovary 2-3-celled with axile placentation... . . . . . . . . . . . . . . . . . 39

38. Bitter, glabrous plants with the leaves generally simple and opposite; inflorescence typically a dichasial cyme; stamens usually 4-5=GENTIANACEAE (p. 61).

Mostly hairy plants with usually lobed and alternate leaves; inflorescence often coiled; stamens 5, usually with appendages at the base=HYDROPHYLLACEAE (p. 62).

39. Leaves alternate or opposite; ovary 3-celled; fruit a loculicidal capsule=POLEMONIACEAE (p. 64).

Leaves alternate; ovary 2 -celled; fruit a capsule or a berry $=\operatorname{SOLANACEAE~(p.~64).~}$

\section{Distribution of Genera}

Adoxa Moschatellina (Musk-root) ANW. It occurs in rocky woods.

Apocynum (Dogbane; Indian Hemp) NESW. $6 \mathrm{sp.}$

Cephalanthus (See page 71).

Cuscuta (Dodder) ESPW. 5 sp.

Dianthera americana (Water-willow) ES. It has narrow leaves, flower-spike on a long peduncle, and grows in water.

Diapensia lapponica (Diapensia) ANE. It occurs only in arctic and alpine situations.

Fraxinus (Ash) ESP. $5 \mathrm{sp.} \mathrm{The} \mathrm{White} \mathrm{Ash} \mathrm{(} F$. americana) has stalked leaflets and glabrous twigs and occurs in rich woods. The Red Ash ( $F$. pennsylvanica) has stalked leaflets and hairy twigs and occurs mostly in moist soil. The Black Ash ( $F$. nigra) has sessile leaflets and naked flowers and is found in swamps. The Blue Ash ( $F$. quadrangulata) has 4 -sided twigs and is confined to southern Ontario.

Lagotis (See p. 69).

Limonium carolinianum (Sea-lavender) NE. The flowers are in one-sided groups and are pale-purple in colour. It occurs in salt marshes.

Littorella uniflora (Shore-weed) E. It occurs in shallow water at the margins of lakes.

Phryma Leptostachya (Lopseed) ES. It occurs in woods.

Plantago (Plantain) ANESPW. $16 \mathrm{sp.} \mathrm{Sea-plantain} \mathrm{(} P$. maritima) has linear leaves and occurs in salt marshes on both Atlantic and Pacific coasts.

Statice Armeria (Sea-pink) ANEW. It occurs on rocky sea-coasts.

Tecoma radicans (Trumpet-creeper) S. It occurs only on Pelee island in lake Erie. 


\title{
SYMPETALOUS DICOTYLEDONS--PYROLACEAE, MONO- TROPACEAE, ERICACEAE, VACCINIACEAE, PRIMULACE
}

\author{
PYROLACEAE
}

1. Leaves alternate, basal; flowers in a raceme $=$ Pyroln.

Leaves opposite or whorled. . . . . . . . . . . . . . . . . . . . . . . . . .

2. Leaves mostly basal; flower solitary $=$ Moneses.

Stem leafy; flowers in an umbel-like group=Chimaphila.

\section{Distribution of Genera} woods.

Chimaphila (Prince's Pine; Pipsissewa) NESW. 3 sp. They occur in dry coniferous

Moneses uniflora (Single Beauty) ANEW. It occurs in cold coniferous woods.

Pyrola (Wintergreen) ANESPW. $12 \mathrm{sp.} \mathrm{The} \mathrm{species} \mathrm{oacur} \mathrm{in} \mathrm{coniferous} \mathrm{woods.} \mathrm{There}$ are usually no green leaves in Leafless Wintergreen ( $P$. aphylla) a species confined to the western region.

\section{MONOTROPACEAE}

1. Plants with white stems and white, solitary nodding flowers which turn black on drying; petals free $=$ Monotropa.

Flowers in dense spikes. . . . . . . . . . . . . . . . . . . . . . . . . . . . . . . . . .

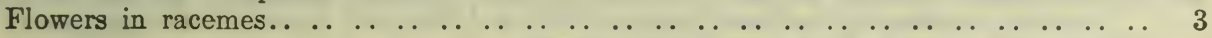

2. White plants with $2-4$ sepals, $4-5$ petals, and 1-celled ovary with parietal placentation= Hemitomes.

Reddish plants with 5 sepals, no corolla and 5-celled ovary with axile placentation= Allotropa.

3. Base of stem enlarged and bulb-like; flowers drooping, all alike; petals united, persistent; seeds winged =Pterospora.

Raceme one-sided; terminal flower different from the lateral ones; petals separate, deciduous=Hypopitys.

\section{Distribution of Genera}

Allotropa virgata (Crownless Pinesap) W. It occurs in dry coniferous woods.

Hemitomes congestum (Cone-plant) W. It occurs in woods.

Hypopitys (Pine-sap) ESW. $4 \mathrm{sp.}$ The species occur in coniferous woods.

Monotropa uniflora (Indian Pipe) ESW. It occurs in woods.

Pterospora andromedea (Pine-drops) ESW. It occurs in coniferous woods.

\section{ERICACEAE}

The members of this family are mostly shrubs with simple, alternate, exstipulate, more or less leathery leaves. The inflorescence is usually of the racemose type. The flowers are bisexual and actinomorphic. Sepals 4-5; petals 4-5, united; stamens usually 8-10, opening mostly by pores. Pollen-grains united in groups of 4 . Ovary superior, composed of 4-5 united carpels, with axile placentation. There is one style with a capitate stigma. The fruit is usually a capsule although sometimes fleshy and the seeds are generally numerous.

As exceptions to the above definitions the leaves are sometimes opposite, the petals may be free, and the stamens 5 in number.

1. Some or all of the leaves opposite or whorled; fruit a capsule .. . . . . . . 2

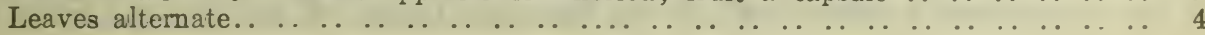


2. Leaves linear-oblong with revolute margins; flowers solitary, or few in number at the ends of the branches; stamens 5; ovary 2 -3-celled=Loiseleuria.

Stamens 8-10; ovary 4-5-celled.. . . . . . . . . . . . . . . . . . . . . . . . . . . . . . 3

3. Leaves large, mostly over an inch long, often in whorls of 3 ; flowers grouped in an umbellate manner; corolla saucer-shaped, with 10 pouches into which the anthers are at first inserted = Kalmia.

Low tufted shrubs with small sessile, opposite, appressed leaves less than $\frac{1}{4}$ of an inch long, flowers solitary; corolla campanulate; anthers with horns=Cassiope.

4. Fruit a capsule. . . . . . . . . . . . . . . . . . . . . . . . . . . . . . 5

Fruit fleshy or apparently so.. . . . . . . . . . . . . . . . . . . . . 13

5. Tufted shrubs with sessile, crowded, appressed leaves less than $\frac{1}{4}$-inch long; flowers solitary and terminal, white; anthers horned $=$ Cassiope.

Flowers mostly in umbellate groups; anthers rarely horned.. . . . . . . . . . 6

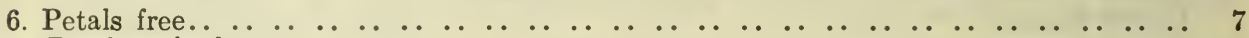

Petals united.. . $\ldots \ldots \ldots \ldots \ldots \ldots \ldots \ldots$

7. Resinous shrubs with fragrant, evergreen leaves which have revolute margins; flowers in umbellate groups, white in colour $=$ Ledum.

Leaves flat, deciduous; flowers solitary, coppery-red in colour=Cladothamnus.

8. Plants trailing, almost herbaceous, with rusty hairs on the stem and evergreen oval leaves which are cordate at the base; flowers dimorphous; corolla salver-shaped, rose-coloured; anthers opening longitudinally=Epigaea.

Erect shrubs; leaves not cordate at the base; anthers opening by pores.. . . . $\quad 9$

9. Leaves leathery, evergreen, with scurfy scales; flowers white, in a one-sided raceme with leafy bracts=Chamaedaphne.

Flowers not in a one-sided, leafy raceme. . . . . . . . . . . . . . . . . . 10

10. The parts of the flower are in fives....................... 11

Parts of the flower in fours; corolla urn-shaped, reddish-yellow; seeds pointed at each end $=$ Menziesia.

11. Leaves linear, whitish on the lower side, with revolute margins; flowers drooping; corolla urn-shaped; anthers horned; fruit a loculicidal capsule=Andromeda.

Anthers not horned; fruit a septicidal capsule.. . . . . . . . . . . . . . . . 12

12. Flower buds scaly; leaves exceeding $\frac{1}{2}$ inch in length; corolla 2-lipped or campanulate. seeds flattened $=$ Rhododendron.

Leaves less than $\frac{1}{2}$ inch long, crowded, linear, with serrulate margins; corolla urnshaped or campanulate; seeds angular or rounded $=$ Phyllodoce.

13. Anthers awned; the calyx becomes fleshy and encloses the capsule, resembling a berry $=$ Gaultheria .

The calyx does not become fleshy, the fruit being a true berry or drupe . . . . 14

14. Trailing shrubs; anthers horned; fruit a red or black drupe with 5-10 stones= Arctostaphylos.

Trees with red flaky bark and shining, evergreen leaves $2 \frac{1}{2}-5$ inches long; anthers not horned; fruit an orange-red berry with many seeds=Arbutus.

\section{Distribution of Genera}

Andromeda Polifolia (Wild Rosemary) ANESW. It occurs in peat bogs.

Arbutus Menziesii (Madroña) W.

Arctostaphylos (Bearberry) ANESW. 5 sp. Alpine Bearberry (A. alpina) occurs on mountains only.

Cassiope (Moss-heather) ANEW. $4 \mathrm{sp}$. The species all occur in alpine or arctic situations.

Chamaedaphne calyculata (Leather-leaf). NEW. It occurs in swampy situations.

Cladothamnus pyrolaeflorus (Copper-bush). W.

Epigaea repens (Trailing Arbutus) ESP.

Gaultheria (Wintergreen) ESW. 4 sp. The only eastern species is the Checkerberry (G. procumbens) with aromatic, leathery evergreen leaves and red fruit. Of the western species the Salal ( $G$. shallon) has an urn-shaped corolla and black edible fruit. All the species occur in forests.

Kalmia (Laurel) ANESW. 3 sp. The anthers when touched by an insect spring out of the pouches with a sudden jerk. In the Mountain Laurel ( $K$. latifolia) the leaves are 
generally alternate, the flowers are termina: and are $\frac{3}{4}$ inch in diameter. It occurs chiefly in rocky woods. In the Sheep Laurel $(K$. angustifolia) the flowers are in lateral groups and are about $\frac{t}{f}$ inch in diameter. It occurs in moist soil. In the Pale Laurel (K. polifolia) the leaf-margins are revolute, the flowers are in terminal groups and are $\frac{1}{2}$ inch in diameter. It occurs in swampy ground. All the above species are poisonous.

Ledum (Labrador-tea) ANEW. $3 \mathrm{sp}$. In Broad-leaved Labrador-tea (L. groenlandicum) the leaves have rusty hairs underneath and are about $\frac{1}{2}$ inch wide with revolute margins, while the stamens are 5-7 in number. All the species occur in swamps.

Loiscleuria procumbens (Trailing Loiseleuria) ANEW. It occurs chiefly in alpine and arctic situations.

Menziesia ferruginea (Fool's Huckleberry) W. It occurs in woods.

Phyllodoce (American Heather) ANEW. $3 \mathrm{sp}$. Only one species is found in the east, namely, Mountain Heath ( $P$. coerulea) which occurs in alpine and arctic situations. Of the two western species Red Heather ( $P$. empetriformis) has pink flowers while Yellow Heather ( $P$. glanduliflora) has yellow flowers.

Rhododendron (Rhododendron) ANISW $\mathbf{5} \mathrm{sp}$. One species, the Dwarf Rhododendron, (R. lapponicum) has brown scales on the leaves and occurs in alpine and arctic situations. Of the two eastern species the Early-flowering Rhododendron ( $R$. canadense) has a 2-lipped corolla and the flowers appear before the leaves: the Tall Rhododendron ( $R$. maximum) has leaves over 4 inches long and a campanulate corolla. Of the two western species the Western Rhododendron ( $R$. californicum) has a terminal inflorescence and pink flowers, while the White-flowered Rhododendron ( $R$. albiflorum) has a lateral inflorescence and white flowers.

\section{VACCINIACEAE}

1. Dwarf plants with creeping or trailing stems; corolla deeply cleft into 4 reflexed lobes; fruit a red berry $=$ Oxycoccus.

Corolla urn-shaped or campanulate, composed of 4 or 5 petals... . . . . . . . 2

2. Plants prostrate, with the leaves in 2 rows; flowers solitary, axillary, white in colour; sepals 4 ; fruit a snow-white berry=Chiogenes.

Plants usually erect, with the flowers grouped racemosely; berry black or red.. . . 3

3. Stem creeping but with erect, leafy, branches; leaves with black dots on the lower side; flowers in one-sided drooping racemes, 4-merous; fruit a red berry $=$ Vaccinium Vitisidaea.

Plants erect; flowers mostly 5 -merois; berry mostly black or red.. . . . . . . .

4. Ovary 10-celled; fruit a berry-like drupe with 10 one-seeded nutlets=Gaylussacia.

Ovary 4-5-celled or incompletely 10-celled; fruit a many-seeded berry=Vaccinium.

\section{Distribution of Genera} woods.

Chiogenes hispidula (Creeping Snowberry) NEW. It has a hispid stem and occurs in wet

Gaylussacia (Huckleberry) ES. $2 \mathrm{sp}$. They occur mostly in wet sandy soil.

Oxycoccus (Cranberry) ANESPW. 2 sp. They occur in peat bogs.

Vaccinium (Blueberry: Bilberry) ANESPW. $15 \mathrm{sp}$. All the eastern species have blue or black fruits with the exception of the Cowberry (V. Vitis-Idaea) which has a red fruit and Deerberry ( $V$. stamineum) which has the flowers in leafy-bracted racemes and a green or vellow fruit. The former occurs on the higher mountains and in northern latitudes while the latter is confined to woods in southern Ontario. Of the exclusively western species two have red fruits, namely, Grouse-berry (V. scoparium) and Red Bilberry (V. parvifolium). The former is about a foot high, has serrate leaves and occurs on mountains, while the latter is 4 feet or more in height, has entire leaves, and occurs in woods.

\section{PRIMULACEAE}

1. Stem leafy. . . . . . Leaves in a rosette at the base of the stem or an apparent whorl under the inflor-

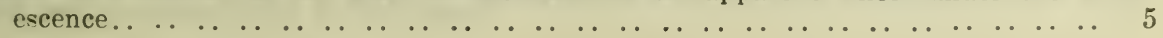

2. Leaves mostlv alternate. . . . . . . . . . . . . . . . . . . . . . . . . . . . 3

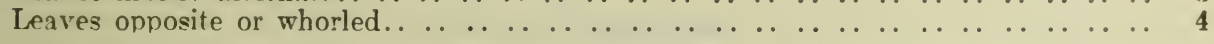

3. Annual plants with solitary axillary flowers; corolla shorter than the calyx; capsule circumscissile $=$ Centunculus.

Perennial plants with flowers in racemes; in addition to the five stamens there are 5 staminodes; ovary partly inferior; capsule opening by valves=Samolus. 
4. Leaves opposite; flowers solitary, axillary; sepals 5 , pink in colour; petals absent= Glaux.

Leaves opposite or whorled; flowers axillary or in terminal groups; petals present, yellow in colour =Lysimachia.

5. Stem-leaves of two kinds, the lower small and scale-like, the upper broad and in an apparent whorl under the flowers; sepals, petals, and stamens usually 7 in number =Trientalis.

Sepals, petals, and stamens 5 in number. . . . . . . . . . . . . . . . . . 6

6. Leaves basal; flowers in umbels; sepals and petals reflexed; filaments united and anthers linear $=$ Dodecatheon.

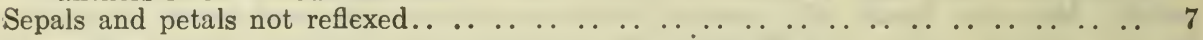

7. Perennial plants; corolla-tube equalling or exceeding the calyx; style filiform... 8 Annual or perennial plants; corolla-tube shorter than the calyx and constricted at the throat; style very short=Androsace.

8. Leaves all basal; flowers in umbels; capsule many-seeded=Primula.

Leaves crowded at the ends of the branches; flowers in umbels or solitary; capsule with 1-2 seeds=Douglasia.

\section{Distribution of Genera}

Androsace (Ray-pimpernel) ANPW. 9 sp.

Centunculus minimus (Chaffweed) W. It occurs in moist ground.

Dodecatheon (Shooting Star) ANEPW. $13 \mathrm{sp}$. The only species found in the east is American Cowslip (D. Meadia) with rose-coloured flowers.

Douglasia (Mountain-pink) AW. 2 sp.

Glaux maritima (Sea-milkwort) EPW. It occurs on the seacoast and in saline soil in the interior.

Lysimachia (Yellow Loosestrife) ESPW. $6 \mathrm{sp.} \mathrm{Crosswort} \mathrm{(L.} \mathrm{quadrifolia)} \mathrm{is} \mathrm{confined}$ to the east, has the leaves usually in whorls of 4 and axillary flowers; Swamp-candles ( $L$. terrestris) produces long bulblets in the axils of the leaves; Fringed Loosestrife ( $L$. ciliata) has ciliate petioles and axillary flowers; Tufted Loosestrife ( $L$. thyrsiflora) has the flowers in dense racemes in the axils of the leaves. All these species occur in swamps or wet places.

Primula (Primrose) ANEPW. $9 \mathrm{sp}$. The species are mostly found in arctic or northern districts.

Samolus floribundus (Brookweed) ESW. It occurs in wet places.

Trientalis (Star-flower) NESPW. 4 sp. Chickweed Wintergreen ( $T$. americana) a smooth perennial with white flowers, is the only eastern species and occurs in woods. 


\section{SYMPETALOUS DICOTYLEDONS - GENTIANACEAE, CONVOLVULACEAE, ASCLEPIADACEAE, HYDRO- PHYLLACEAE, BORAGINACEAE, POLE- MONIACEAE, SOLANACEAE}

\section{GENTIANACEAE}

1. Annual or biennial plants with the leaves reduced to awl-shaped scales; petals 4, imbricated in the bud=Bartonia.

Leaves normal; petals not imbricated in the bud.. . . . . . . . . . . . 2

2. Aquatic perennials with alternate leaves; petals 5 , induplicate-valvate in the bud.. 3 Leaves opposite; petals $4-5$, convolute in the bud.. . . . . . . . . . . . . 4

3. Leaves simple, cordate at the base, floating, with an umbel of flowers and a cluster of tubers arising from the same node $=N$ ymphoides.

Leaves trifoliolate, not floating; flowers grouped racemosely; corolla bearded on the inside with white hairs=Menyanthes trifoliata.

Leaves reniform, crenate; flowers on scapes, in a short cyme; corolla white, the lobes not bearded, but with a median crest=Menyanthes Crista-galli.

4. Corolla campanulate, 4-lobed, usually with 4 hollow spurs which are glandular at the base=Halenia.

Corolla not spurred............................. 5

5. Corolla cylindrical or campanulate, $4-5$-lobed=Gentiana.

Corolla rotate.. .............................. 6

6. Leaves in whorls of 4 ; petals 4 , yellowish, with brown-purple dots; each petal bears a fringed gland about the middle $=$ Frasera.

Leaves generally opposite; petals $4-5$, without glands.. . . . . . . . . . . 7

7. Corolla blue or white; petals with a pair of scale-like appendages at the base; anthers straight; style absent $=$ Pleurogyne.

Corolla rose-pink with a greenish eye; petals without scale-like appendages; anthers recurved; style filiform $=$ Sabbatia.

\section{Distribution of Genera}

Bartonia (Bartonia) ES. 2 sp. Yellow Bartonia (B. virginica) has yellow flowers and occurs in moist soil, while Purple Bartonia (B. iodandra) with leaves usually alternate and purplish flowers is found in bogs.

Frasera carolinensis (American Columbo) S. It occurs in dry soil.

Gentiana (Gentian) ANESPW. 35 sp.

Halenia deflexa (Spurred Gentian) NESPW. It has purplish or white flowers and occurs in damp woods.

Menyanthes (Bog-bean) ANEW. $2 \mathrm{sp.} \mathrm{Deer-cabbage} \mathrm{(M.} \mathrm{Crista-galli)} \mathrm{is} \mathrm{confined} \mathrm{to}$ the West.

Nymphoides lacunosum (Floating Heart) ES. It has white flowers.

Pleurogyna rotata (Marsh Felwort) ANEW. It occurs in marshy ground.

Sabbatia (Rose-pink) ES. 2 sp. Square-stemmed Rose-pink (S. angularis) has a foursided stem and leaves clasping at the base.

\section{CONVOLVULACEAE}

Plants. with a very large root; there are no bracts under the calyx; seed hairy= Ipomøa.

There are 2 leafy bracts under the calyx; seeds glabrous=Calystegia. 


\section{Distribution of Genera}

Calystegia (Bindweed) ESPW. $4 \mathrm{sp.} \mathrm{Great} \mathrm{Bindweed} \mathrm{(C.} \mathrm{sepium)} \mathrm{has} \mathrm{a} \mathrm{twining} \mathrm{stem}$ and triangular leaves; Dwarf Bindweed (C. spithamcea) has oval leaves with a blunt tip, white flowers, and occurs in dry soil; Sea Bindweed (C. soldanella) has a trailing stem, kidney-shaped leaves, purplish flowers, and occurs only on sandy shores on the Pacific coast.

Ipomœe pandurata (Wild Potato-vine) S. It occurs in dry ground.

\section{ASCLEPIADACEAE}

Leaves mostly opposite; hoods of the corona each provided with a horn-like process = Asclepias.

Leaves opposite or alternate; hoods of the corona without horns $=$ Gomphocarpus.

\section{Distribution of Genera}

Asclepias (Milkweed) ESPW. $11 \mathrm{sp.} \mathrm{Only} \mathrm{one} \mathrm{species,} \mathrm{Showy} \mathrm{Milkweed} \mathrm{(A.} \mathrm{speciosa)}$ with broad leaves and purplish flowers, extends into the western region. The Orange Butterfly Weed (A. tuberosa) with leaves mostly alternate and orange flowers occurs only in southern Ontario. In Four-leaved Milkweed ( $A$. quadrifolia) some of the leaves are in whorls of four; it occurs in woods in southern Ontario. Whorled Milkweed ( $A$. verticillata) has sessile linear leaves in whorls of 3-7, greenish-white flowers and extends from the southern to the prairie region.

Gomphocarpus (Green Milkweed) SP. $2 \mathrm{sp.} \mathrm{Green-flowered} \mathrm{Milkweed} \mathrm{(G.} \mathrm{viridiflorus)}$ has the umbels almost sessile. It occurs in dry soil and ranges from southern Ontario to the prairie.

\section{HYDROPHYLLACEAE}

1. Leaves mostly basal, reniform, and crenately lobed; style filiform, not divided at the tip; capsule nearly 2-celled owing to the intrusion of the placentas $=$ Romanzoffia. Leaves mostly cauline; style bifid at the tip.. . . . . . . . . . . . . . . 2

2. Leaves simple or pinnately divided; flowers in terminal coiled cymes; corolla-lobes imbricated in the bud; stamens usually longer than the corolla = Phacelia.

Corolla-lobes convolute in the bud.. . . . . . . . . . . . . . . . . . . . . 3

3. Mostly perennial, with palmately lobed or pinnately divided leaves; flowers in coiled cymes; stamens longer than the corolla $=$ Hydrophyllum.

Annuals with alternate or opposite leaves; flowers solitary, opposite to the leaves; stamens shorter than the corolla.. . . . . . . . . . . . . . . . . . . . . . . . 4

4. Calyx with an appendage in each sinus between the lobes; corolla with 10 appendages within = Nemophila.

Calyx without appendages; corolla with 5 appendages within = Ellisia.

\section{Distribution of Genera}

Ellisia Nyctelea (Broad Cup) PW. It grows in moist shady places.

Hydrophyllum (Water-leaf) ESW. $7 \mathrm{sp}$. The only eastern species is Virginian Waterleaf $(H$. virginianum). It has pinnately divided leaves. Of the two southern species the Appendaged Water-leaf ( $H$. appendiculatum) is biennial, has the lower leaves pinnately divided, and has an appendage in each notch of the calyx; while the Broad-leaved Waterleaf ( $H$. canadense) usually has all the leaves palmately lobed. The above three species occur in woods.

Nemophila (Grove-lover) W. $6 \mathrm{sp}$.

Phacelia (Scorpion-weed) NW. 9 sp.

Romanzoffia (Kidney-leaf) W. 3 sp.

\section{BORAGINACEAE}

The Canadian members of this family are all herbs, usually covered with bristly hairs. Leaves alternate, exstipulate, simple, and entire. The inflorescence is usually a one-sided cyme, coiled up like a watch-spring when young. The flowers are actinomorphic and bisexual with the parts in fives, except the carpels which are 2 in number. The corolla is sympetalous, has a short tube, and frequently has appendages at the throat. The stamens are epipetalous. Ovary superior, 4-celled and 4-lobed, with the style springing from the centre of the lobes. Stigmas simple or bifid. Fruit a schizocarp, separating into 4 oneseeded nutlets. 
There are few exceptions to the above general characters. Heliotropium and several species of Mertensia are glabrous while the lower leaves in Allocarya are opposite. The style in Heliotropium is terminal.

1. Glabrous plants with undivided ovary and terminal style $=$ Heliotropium.

Ovary 4-lobed and style proceeding from the centre of the lobes.. . . . . . . 2

2. Fruit provided with barbed or hooked prickles................. 3

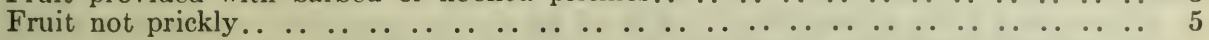

3. Annuals, dichotomously branched, with linear leaves and very small white flowers; nutlets diverging in pairs, winged, with hooked prickles $=$ Ctenospermum.

Annual, biennial, or perennial herbs, not branching dichotomously; prickles provided

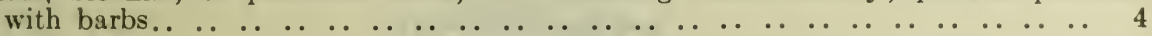

4. Nutlets spreading, flat, covered all over with prickles $=$ Cynoglossum.

Nutlets erect, with the prickles chiefly on the margin = Lappula.

5. Annual plants with the lower leaves opposite and the upper alternate; corolla white; nutlets attached obliquely to the receptacle=Allocarya.

All the leaves are alternate... $\ldots \ldots \ldots \ldots \ldots$

6. Annual plants with very small white flowers; calyx deciduous with the fruit; nutlets attached laterally by their lower half to the pyramidal receptacle $=$ Cryptantha .

Part or all of the calyx persistent... . . . . . . . . . . . . . . . .

7. Annual, dichotomously branched plants with linear leaves; flowers leafy-bracted, sessile, white, very small; upper part of calyx deciduous; nutlets attached hy nearly their whole length to a narrow elongated receptacle $=$ Piptocalyx.

The entire calyx is persistent. . . . . . . . . . . . . . . . . . . . . . . . . . . .

8. Nutlets attached more or less laterally to the receptacle which is generally conical

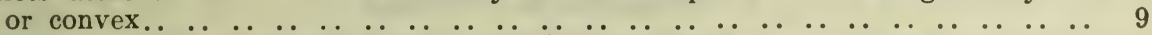

Nutlets attached by the very base to the flat receptacle. $\ldots \ldots \ldots \ldots \ldots \ldots \ldots \ldots \ldots 11$

9. Perennial plants with leafy stems; corolla tubular-funnelform, blue or purple; nutlets generally wrinkled = Mertensia.

Mostly annual or biennial plants with white or yellow flowers.......... 10

10. Annuals with the leaves mostly basal; corolla white; nutlets rough, oblique or incurved, attached about the middle by a caruncle-like process to the globular receptacle = Plagiobothrys.

Annuals with leafy-bracted cymes; corolla yellow; nutlets bony, more or less triangular, attached below the middle to the elongated receptacle = Amsinckia .

Biennials or perennials with leafy-bracted cymes; calyx-lobes spreading; corolla white or cream-coloured, crested in the throat; nutlets triangular, attached almost throughout their length to a columnar receptacle=Oreocarya.

11. Perennial plants with leafy-bracted cymes; corolla tubular, with acute lobes, yellow, white or green in colour; nutlets white and shining = Onosmodium.

Perennial plants with leafy-bracted cymes; corolla funnelform, with rounded lobes, white or yellow in colour; nutlets white, smooth and shining, or brown and wrinkled =Lithospermum.

Annual, biennial, or perennial plants; cymes without bracts; corolla funnelform, with rounded lobes, crested in the throat, blue or white in colour; nutlets ovoid, smooth and shining $=$ Myosotis.

\section{Distribution of Genera}

Allocarya (Opposite-leaved Scorpion-grass) PW. $6 \mathrm{sp.}$

Amsinckia (Fiddle-neck) W. 4 sp.

Cryptantha (Nievitas) PW. 9 sp.

Ctenospermum penicillatum (Forked Stickseed) W. It occurs in sandy soil.

Cynoglossum (Hound's Tongue) EWS. $4 \mathrm{sp}$. Northern Hound's Tongue ( $C$. boreale)

is the only indigenous species in the East and is found in woods; the upper part of the stem

is leafless and the corolla is pale-blue in colour.

Heliotropium spathulatum (Heliotrope) P. It is a glaucous, fleshy, perennial.

Lappula (Stickseed) ESPW. $14 \mathrm{sp.}$

Lithospermum (Gromwell; Puccoon) ESPW. 6 sp. The Hoary Puccoon (L. canescens)

has an orange-yellow corolla with entire lobes and occurs in dry soil.

Mertensia (Lungwort) ANESPW. $12 \mathrm{sp}$. Sea Lungwort (M. maritima) is a glaucous

fleshy plant found only on the sea-coast on both Atlantic and Pacific shores. Lance-leaved 
Lungwort ( $M$. lanceolata) is nearly glabrous, has blue flowers, and occurs on the Prairie. The only southern species is Virginian Cowslip ( $M$. virginica); it is glabrous, has a trumpetshaped, scarcely lobed, bluish-purple corolla and occurs along streams.

Myosotis (Scorpion-grass; Forget-me-not). ANESW. 6 sp. The smaller Forget-me-not (M. laxa) is a perennial, has a blue corolla with yellow eye, and occurs in wet places.

Onosmodium (False Gromwell) SP. 2 sp. Western False Gromwell (O. occidentale) is confined to the prairie while Shaggy False Gromwell ( $O$. hispidissimum) occurs only in the southern region. Both species are found in dry soil.

Oreocarya (White Forget-me-not) PW. $4 \mathrm{sp.}$

Piptocalyx circumscissa (Drop-cup) W. It occurs in dry soil.

Plagiobothrys (Popcorn-flower) W. $3 \mathrm{sp.}$

\section{POLEMONIACEAE}

1. Mostly perennials with alternate, compound, unequally pinnate leaves; corolla campanulate to funnelform=Polemonium.

Leaves alternate or opposite, simple or divided into narrow segments. . . . . . 2 2

2. Annual plants with alternate, mostly simple leaves and flowers in head-like clusters; calyx enlarging in fruit but not ruptured by the capsule=Collomia.

Leaves alternate or opposite; calyx mostly ruptured by the capsule.. . . . . . . 3

3. Some or all of the leaves opposite and simple.. . . . . . . . . . . . . . . 4 Leaves mostly alternate and divided=Gilia.

4. Mostly perennial plants with all the leaves opposite $=$ Phlox.

Annual plants with the lower leaves opposite and the upper alternate; seeds mucilaginous when wetted $=$ Microsteris.

\section{Distribution of Genera}

Collomia (Collomia) W. 5 sp.

Gitia (Gilia) PW. 11 sp. Only 2 species occur on the prairie, namely Dwarf Gilia ( $G$. minima) which is annual and almost glabrous and Dense-flowered Gilia ( $G$. congesta) which is perennial and hairy. Both the above species have white flowers.

Microsteris (Annual Phlox) W. 2 sp.

Phlox (Phlox) ANESPW. $14 \mathrm{sp.} \mathrm{Of} \mathrm{the} \mathrm{eastern} \mathrm{species} \mathrm{Blue} \mathrm{Phlox} \mathrm{(} P$. divaricata) has some of the shoots prostrate and has bluish flowers; it occurs in woods. Moss Pink ( $P$. subulata) has tufted stems, tufted subulate leaves and rose-coloured flowers; it occurs in dry soil and is confined to the southern region. White Prairie Phlox (P. Hoodii) is a dwarf tufted species with subulate leaves and white flowers occurring on the prairie.

Polemonium (Jacob's Ladder; Skunk-weed) ANPW. 8 sp. Small flowered Skunkweed ( $P$. micranthum) is an annual species with white, nearly rotate corolla occurring on dry ground in the West. Prairie Skunk-weed ( $P$. occidentale) has an underground stem and blue or violet flowers, and is the only species occurring on the prairie.

\section{SOLANACEAE}

1. Annual plants with viscid hairs; corolla with a long tube; fruit a capsule=Nicotiana.

Annual or perennial plants; corolla plicate in the bud; fruit a berry.. . . . . . . . 2

2. Flowers mostly solitary in the axils of the leaves; calyx generally becoming enlarged and enclosing the ripe fruit; corolla mostly campanulate, rarely rotate; anthers opening by slits $=$ Physalis.

Calyx not enlarging; corolla rotate; anthers opening by pores=Solanum.

\section{Distribution of Genera}

Nicotiana attenuata (Wild Tobacco) W. It has white or greenish flowers and occurs on dry ground.

Physalis (Ground-cherry) ESPW. $7 \mathrm{sp.} \mathrm{Clammy} \mathrm{Ground-cherry} \mathrm{(} P$. grandiflora) is a viscid annual species with rotate corolla, white in colour with yellow centre, and calyx not much enlarged in fruit. It occurs in sandy soil both in the east and on the prairie. Strawberry Tomato ( $P$. pruinosa) is a hairy annual with cordate, toothed leaves and is confined to the southern region.

Solanum triflorum (Cut-leaved Nightshade) EPW. It is an annual with pinnatifid leaves and greenish fruit. 


\section{SYMPETALOUS DICOTYLEDONS - LABIATAE, VER- BENACEAE, OROBANCHACEAE, LENTIBULARIACEAE, SCROPHULARIACEAE}

\section{LABIATAE}

The members of this family are mostly strong-scented herbs with four-sided stems and decussate, simple, exstipulate leaves. The inflorescence has an apparently whorled arrangement at the nodes but is really a short dichasial cyme in the axil of each leaf, with onesided development in the later stages. The flower is usually bisexual and zygomorphic. Calyx tubular, sometimes 2-lipped. Corolla markedly bilabiate. Stamens epipotalous, typically 4 in number with one pair longer than the other, but sometimes only two stamens are present. Ovary superior, synearpous, becoming 4-celled with a single ovule in each cell. Style mostly gynobasic, springing from the centre of the 4-lobed ovary. Stigma bifid. Fruit a schizccarp, consisting of four nutlets.

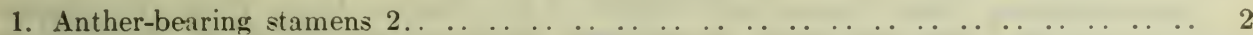

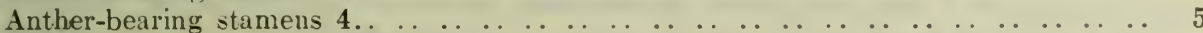

2. Perennial plants with flowers in a terminal, loosely branched, paniculate inflorescence; calyx 2-lipped; corolla yellow = Collinsonia.

Perennial plants with the flowers in a terminal head-like eluster; calyx equally 5-toothed, hairy in the throat = Monarda.

Flowers in axillary, or axillary and terminal clusters. . . . . . . . . . . . . . 3

3. Mostly stoloniferous plants without any marked odour; flowers in dense clusters at the nodes, mostly white; calyx scarcely 2-lipped; corolla 4-lobed, the lobes being nearly equal, or one of them slightly broader and notched=Lycopus.

Calyx markedly 2-lipped; corolla bilabiate, purple or bluish-purple.. . . . . . . 4

4 Annual plants with the flowers in axillary clusters=Hedeoma.

Perennial plants with the flowers in both axillary and terminal clusters=Blephilia.

5. The nutlets are attached laterally and the style is not basal. . . . . . . . . . 6

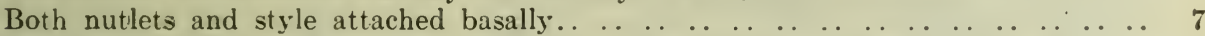

6. Perennial plants; calyx 2-lipped, with unequal teeth; corolla almost 1-lipped, with very unequal lobes $=\dot{T}$ eucrium.

Annual plants; calyx teeth almost equal; corolla lobes almost equal=Isanthus.

7. Flowers mostly solitary in the axils of the leaves or bracts in raceme-like groups; calyx 2-lipped, with entire margins and a helmet-shaped protuberance on the upper lip = Scutellaria.

Calyx 5-toothed, without a protuberance on the upper lip.. . . . . . . . . 8

8 Flowers in terminal head-like groups, white or purple-spotted; calyx-teeth equal or slightly unequal=Pycnanthemum.

Flowers in axillary or terminal mostly spike-like groups. . . . .

9. Odoriferous perennials with trailing stem and solitary axillary flowers; calyx teeth about equal; corolla white=Micromeria.

Stems erect, with usually several flowers clustered in the axils.. . . . . . . . . 10

10. Calyx 2-lipped, with some of the teeth distinctly larger than the others.... . . 11

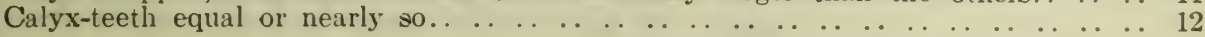

11. Annual or biennial plants with the flowers in a dense terminal spike-like group; bracts pectinate; one of the calyx-teeth is nuch larger than the others=Moldavica.

Stoloniferous perennials with both axillary and terminal flowers; bracts not pectinate; two of the calyx-teeth are larger than the other three=Clinopodium. 
12. Plants very aromatic, with rhizomes; corolla scarcely bilabiate, 4-lobed, with one of the lobes broader than the others and frequently notched. stamens equal in length= Mentha.

Corolla strongly bilabiate, the upper lip being concave; stamens unequal in length. 13

13. Plants with broadly ovate leaves and flowers in a dense or interrupted, terminal spikelike group; upper pair of stamens longer than the lower pair=Agastache.

Upper pair of stamens shorter than the lower pair.. $\ldots \ldots \ldots \ldots$

14. Flowers occurring singly in the axils of bracts forming a tcrminal raceme; calyx faintly nerved, somewhat inflated in fruit; stamens with hairy filament=Dracocephalum.

Flowers mostly in axillary clusters at the nodes; calyx 5-10-ncrved=Stachys.

\section{Distribution of Genera}

Agastache (Giant-hyssop) NESPW. 4 sp. Fragrant Giant-hyssop (A. anethiodora) has blue flowers and is the only species found in the prairic region. The other species occur in woods.

Blephilia (Wood-mint) ES. 2 sp. They have purple flowers and occur in woods.

Clinopodium (Basil) ESPW. 2 sp. Wild Basil (C. vulgare) has ovate hairy leaves and clustered flowers and occurs in woods. Smooth Calamint (C. glabrum) has glabrous linear leaves and sparsely grouped flowers. It occurs on rocky banks in the southern region only.

Collinsonia canadensis (Horsc-balm) ES. It has a large woody root, leaves 6 inches or more in length and occurs in moist woods.

Dracocephalum (False Dragon-head) ESPW. 2 sp. Eastern Lion's Heart (D. virginianum) has flowers $\frac{3}{4}$ inch long and is eastern, while Western Lion's Heart (D. Nuttallii) has flowers $\frac{1}{2}$ inch long and is found from the prairie westwards. Both species occur in moist soil.

Hedeoma (Mock Pennyroyal) ESP. 2 sp. Eastern Pcnnyroyal (H. pulegioides) has serrate leaves and is eastern while Narrow-leaved Pennyroyal ( $H$. hispida) has linear, entire leaves and extends to the prairie. Both species occur on dry soil.

Isanthus brachiatus (False Pennyroyal) ES. It is an extensively branched plant with blue flowers and occurs on sandy soil.

Lycopus (Water-horehound; Bugle-weed) NESPW. 6 sp. They occur in wet soil.

Mentha (Mint) NESPW. 5 sp. They occur mainly in wet places.

Micromera Chamissonis (Yerba Buena) W. It occurs in woods. soil.

Moldavica parviflora (Dragon-head) NEW. It has light-blue flowers and occurs in dry

Monarda (Balm; Bergamot) ESPW. $6 \mathrm{sp.} \mathrm{Bee-balm} \mathrm{(M.} \mathrm{didyma)} \mathrm{has} \mathrm{scarlet} \mathrm{flowers}$ and occurs on moist soil. The only species found on the prairie is Prairie Horse-mint (M. menthaefolia) with rose-coloured flowers.

Pycnanthemum (Mountain-mint) ES. $3 \mathrm{sp.}$

Scutellaria (Skullcap) NESPW. $7 \mathrm{sp}$.

Stachys (Hedge-nettle; Woundwort) NESPW. 5 sp. The commonest species is Marsh Woundwort (S. palustris) with short thick rhizomes and purplish spotted corolla. It is found in moist soil.

Teucrium (Germander; Wood-sage) ESW. $2 \mathrm{sp.} \mathrm{They} \mathrm{occur} \mathrm{in} \mathrm{moist} \mathrm{soil.}$

\section{VERBENACEAE}

Spikes elongated; corolla with 5 nearly equal lobes; fruit separating into 4 nutlets= Verberia.

Spikes not much longer than broad; corolla two-lipped, with 4-lobes; fruit separating into 2 nutlets=Liippia.

\section{Distribution of Genera}

Linpia lanceolata (Fog-fruit) S. It has pale-blue flowers and occurs in moist soil.

Verbena (Vervain) ESPW. 5 sp. Of the eastern species Nettle-leaved Vervain ( $V$. urticifolia) has white flowers, whilc Blue Vervain (V. hastata) has blue flowers and occurs on damp ground. The only species fouma on the prairie is Large-bracted Vervain ( $V$. bracteosa) in which the bracts are longer than the purplish-blue flowers.

\section{OROBANCHACEAE}

1. Inflorescence branched; the lower flowers do not open but set seeds while the upper flowers open but set no seeds=Epiphegus.

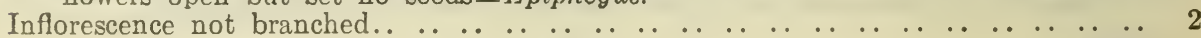


2. There are two bracteoles under the caly: which is slit down one side; stamens exserted, with bristly anthers; capsule 2-valved=Conopholis.

Calyx not slit down one side.. . . . . . . . . . . . . . . . . . . . . . . . . . . 3

3. There is a globose, tuberous, underground stem with densely imbricated, scaly leaves; bracteoles usually absent; capsule 4 -valved=Boschniakia.

Capsule 2-valved.. . . . . . . . . . . . . . . . . . . . . . . . . . . . .

4. Flowers sessile, or nearly so, with one to two bracteoles under each=Orobanche.

Flowers on long stalks, without bractecies=Thalesia.

\section{Distiuibution of Genera}

Boschniakia (Poque) W. 2 sp. It is parasitic on ericaceous plants.

Conopholis americana (Squaw-root) F.S. It occurs mostly under oak trees.

Epiphegus virginiana (Beech-drops) ES. It is parasitic on the roots of beech trees.

Orobanche (Broomrape) PW. 4 sp. Woolly-stamened Broomrape (O. grayana) has purple flowers and occurs on roots of Grindelia in B.C.

Thalesia (Ghost-pipes; Cancer-root) F.SPW. 2 sp. One-flowered Cancer-root ( $T$. uniflora) has a very short stem, so that the flowers, which are white or violet, spring almost from the ground level.

\section{LENTIBULARIACEAE}

Leaves all basal, with inrolled edges, glandular on the upper surface; flowers solitary, violet to purpls: in colour =Pinguicula.

Rootless plants with divided leaves which bear small bladders for capturing minute animals; flowers mostly in a raceme, and yellow in colour=Utricularia.

\section{Distribution of Genera}

Pinguicula (Butterwort) ANEW. 3 sp. They occur mostly in northern bogs.

Utricularia (Bladderwort) ANESPW. 10 sp. One-flowered Bladderwort (U. resupinata) has solitary purple flowers with a bract at the junction of the flower-stalk and peduncle; it is an eastern species.

\section{SCROPHULARIACEAE}

All the Canadian species of this family are herbs with alternate or opposite, exstipulate and generally simple leaves. The inflorescence is generally a raceme, spike, or cyme. The flowers are usually zygomorphic and bisexual. Sepals 5 in number. Corolla sympetalous, mostly 5-lobed and 2-lipped. Fertile stamens 4, in pairs of unequal length, or 2 only, epipetalous. Ovary superior, syncarpous, 2-celled, with axile placentation and numerous ovules. There is a single terminal style. The fruit is a capsule.

A number of genera belonging to this family, such as Euphrasia, are parasitic on the roots of other plants.

1. Lower or all the leaves opposite or whorled. . . . . . . . . . . . . . 2

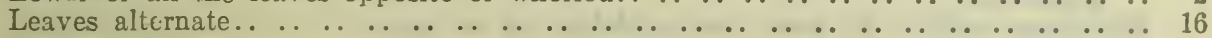

2. There are 4 fertile stamens and 1 staminode.. . . . . . . . . . . . . . 3

There are 4 fertile stamens in pairs of unequal length.. $\ldots \ldots \ldots \ldots \ldots$

There are 2 fertile stamens and 2 staminodes, or 2 fertile stamens only...... 14

3. Annual plants with the upper leaves frequently whorled; flowers blue or violet; corolla deeply cleft on each side into 2 lips, the upper of which is 2-lobed, the lower 3-lobed; the middle lobe of the lower lip is keeled and contains the stamens and style; the sterile stamen is a gland-like structure=Collinsia .

Perennial plants: stamen 3 not inclosed by the lower lip............... . . 4

4. Corolla mostly funnelform; sterile stamen about as long as the others and usually bearded = Pentastemon.

Corolla bilabiate; sterile stamen shorter than the others.. . . . . . . . . . . . 5

5. Corolla white or purple; anthers woolly; sterile stamen filamentous; seeds winged = Chelone.

Plants with unpleasant odour; corolla dull-purple, yellowish, or green, its tube mostly globular in form, the 4 upper lobes erect, and the lower spreading or reflexed; the sterile stamen is a flat scale=Scrophularia. 
6. Corolla salverform or funnelform, scarcely bilibiate.. . . . . . . . . . . . . . . 7

Corolla dist inctly bilabiate . . . . . . . . . . . . . . . . . . . . . . . . . $\ldots$

7. Perennial plants with Howers in a long spike; corolla salverform, purple = Buchnera. Annual or perennial plants with linear or pinnately lobed leaves; flowers in a raceme, or axillary; corolla funnelform, purple or yellow = Gerardia.

8. Leaves pinnately lobed. . . . . . . . . . . . . . . . . . . . . . . . . . . . . . . . . .

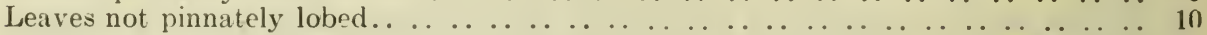

9. Annual plants with flowers mostly solitary and axillary; corolla greenish-white; the stamens are not enclosed by the upper lip of the corolla = Conobra.

Mostly perennial plants with flowers in spikes or racemes; stamens ascending under the upper lip of the corolla = Pedicularis.

10. Flowers, mostly solitary and axillary; calyx prismatic, $\check{5}$-angled, with one of thr calyxteeth usually larger than the others; stigma with wo flat lobes $=$ Mimulus.

Flowers in leafy spikes; calyx usually 4-toothed, not prismatic.. . . . . . . . . . 11

11. Ammual plants; bracts usually toothed at the base; capsule oblique, 1-4 seeded; seet: with an aril at one end = Melampyrum.

Capsule isobilateral, several-seeded; seeds without an aril. . . . . . . . . . . . 12

12. Annual plants with calyx much inflated in fruit; seeds winged = Rhinanthus.

Calyx not inflated and seeds not winged. . . . . . . . . . . . . . . . . 13

13. Annual plants; upper lip of corolla 2-lobed with recurved margins = Euphrasia.

Perennial plants; corolla purple, the margins of the upper lip not recurved; anthers hairy $=$ Bartsia.

14. Sepals 4; corolla mostly rotate with 4 lobes; there are no sterile stamens $=$ Veronica.

Sepals 5; corolla tubular, with 5 lobes; there are usually 2 sterile stamens.. . . . 15

15. Sterile stamens long, 2-lobed, one of the lobes capitate and glandular, the other shorter; seeds wrinkled $=$ Ilysanthes.

Sterile stamens short or absent; seeds both longitudinally and transversely striate = Gratiola.

16. Stamens 2.

Stamens 4.

17. Corolla absent $=$ Synthyris.

Corolla bilabiate; fruit separating into 2 nutlets = Lagotis.

18. Corolla bilabiate.. . . . . . . . . . . . . . . . . . . . . . . . . . . . . . . . . . 19

Plants with stolons, basal leaves and 1-flowered scapes; corolla with 5 subequal lobes; capsule 2-celled at the base, 1-celled above $=$ Limosella .

19. Corolla spurred = Linaria.

Corolla not spurred.

20. Mostly perennial plants; calyx split; anther-sacs alike, parallel; capsule oblique $=$ Pedicularis.

Anther-sacs unlike, the inner one pendulous by its apex... . . . . . . . . . 21

21. Mostly perennial plants; bracts generally brightly coloured; calyx cleft above and below more deeply than on the sides; upper lip of the corolla much longer than the lower = Castilleja.

Annual plants; calyx cleft into 4 almost equal lobes; upper lip of the corolla scarcely longer than the lower=Orthocarpus.

\section{Distribution of Genera}

Bartsia alpina (Alpine Bartsia) A.

Buchnera americana (Blue hearts) S. It occurs in sandy soil.

Castilleja (Painted Cup; Indian Paintbrush) ANESPIV. $28 \mathrm{sp.} \mathrm{Of} \mathrm{the} \mathrm{two} \mathrm{eastern}$ species the Scarlet Painted-cup ( $C$. coccinea) is a hairy biennial or annual species with the upper leaves cleft irregularly into narrow segments.

Chelone (Turtle-head) FSW. $2 \mathrm{sp.} \mathrm{Eastern} \mathrm{Turtle-head} \mathrm{(C.} \mathrm{glabra)} \mathrm{has} \mathrm{white} \mathrm{flowers}$ and occurs in wet ground while Wester', Turtle-head (C. nemorosa) has purple flowers and is confined to the western region.

Collinsia (Blue Lips) ESPIV. 3 sp.

Conobea multifida (Cut-leaved Monkey-flower) S. It is found along streams. 
Euphrasia (Eyebright) ANEW. 6 sp.

Gerardia (Gerardia) ESP. $10 \mathrm{sp.}$

Gratiola (Hedge-hyssop) ESPW. 3 sp). Crolden Hedge-hyssop ( $G$. anjen) is a peremnial species confined to the East; it has the 2 sterile filaments capitate at the summit. Clammy Hedge-hyssop ( $G$. virginiana) is an annual with glandular stem and two bracts under the calyx. All the species oceur in wet places.

Ilysanthe's (False Pimpernel) ISW. 2 sp. Both species occur in wet places.

Lagotis glauca (Aretic Hare's Ear) A.

Limosclla aquatica (Mudwort) NEPW. It occurs on muddy sliores.

Linaria canadensis (Toadflax) EW. It is an annual or biennial with blue flowers occurring in sandy soil.

Melampyrum lincare (Cow-wheat) NEW. It has a greenish-yellow or purplish corolla and occurs in woods.

Mimulus (Monkey-flower) ESPW. $16 \mathrm{sp.} \mathrm{Of} \mathrm{the} \mathrm{eastern} \mathrm{species} \mathrm{Square-stemmed}$ Monkey-flower ( $M$. ringens) has sessile leaves and violet flowers; another species found in the East is Musk-plant (M. moschatus) with viscid hairy stem, ovate leaves, yellow flowers and frequently a musky odour.

Orthocarpus (Owl's Clover) PW. 8 sp. Prairie Owl's Clover (O. luteus) has narrow leaves and yellow flowers; it is the only species found on the prairie.

Pedicularis (Lousewort) ANFSPIV. $23 \mathrm{sp}$. Of the eastern species the Purple Lousewort ( $P$. palustris) is a glabrous annual or biennial with purple flowers and occurs in marshy ground; Swamp Lousewort ( $\boldsymbol{P}$. lanccolata) is a glabrous perennial with yellow flowers and short capsule not much longer than the calyx; while Wood Betony ( $P$. canadensis) is a hairy perennial with yellow or reddish flowers and a capsule about thrice the length of the calyx and is found in dry woods. Of the Arctic species, Elephant-flower ( $P$. groenlandica) has the upper lip prolonged into a beak resembling the snout of an elephant.

Pentastemon (Beard-tongue) ESPIW. $24 \mathrm{sp.} \mathrm{'The} \mathrm{only} \mathrm{eastern} \mathrm{species} \mathrm{is} \mathrm{Hairy} \mathrm{Beard-}$ tongue ( $P$. hirsutus) with violet or purplish corolla, found in dry woods.

Rhinanthus (Yellow Rattle) NEPW. $2 \mathrm{sp.} \mathrm{Northern} \mathrm{Yellow} \mathrm{Rattle} \mathrm{(R.} \mathrm{Crista-galli)}$ with yellow or purple-spotted corolla and flattened capsule is the only eastern species.

Scrophularia (Figwort) ESIW. $5 \mathrm{sp}$.

Synthyris (Kitten-tails) PW. 2 sp.

Veronica (Speedwell) ANESPW. $10 \mathrm{sp}$. Culver's Root (V. virginica) has whorled leaves, flowers in a terminal raceme and tubular, white or bluish corolla. Marsh Speedwell $(V$. scutellata) has sessile, linear leaves, axillary racemes with blue flowers and a very flat capsule; it occurs in swamps. 


\title{
SYMPETALOUS DICOTYLEDONS - CAPRIFOLIACEAE, RUBIACEAE, CUCURBITACEAE, CAMPANULACEAE, LOBELIACEAE, VALERIANACEAE
}

\author{
CAPRIFOLIACEAE
}

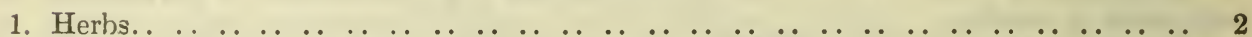

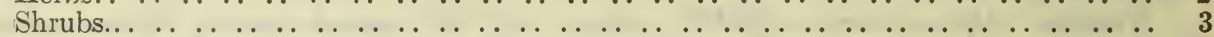

2. Erect plants, with sessile leaves; flowers sessile in the axils of the leaves; fruit an orange drupe with 3 nutlets=Triosteum.

Trailing plants with stalked leaves; flowers in pairs on a long terminal peduncle; stamens 4 , in pairs of unequal length; fruit 1-seeded and indehiscent=Linnaea.

3. Plants with unpleasant odour and pinnately compound leaves; corolla rotate; fruit a berry-like drupe with 3 nutlets=Sambucus.

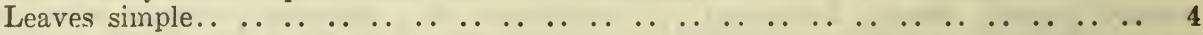

4. Inflorescence terminal; corolla rotate; fruit a 1-seeded drupe with flattened stone $=$ Viburnum.

Corolla tubular; fruit a berry with sereral seeds, or a capsule.. . . . . . . . . 5

5. Calyx with a narrow tube and 5 linear lobes; corolla yellow; fruit a 2-celled capsule $=$ Diervilla.

Calyx with short lobes; fruit a berry........................ . . . . 6

6. Erect or twining shrubs; corolla tubular, often bilabiate; berry 2-3-celled=Lonicera .

Erect shrubs; corolla bell-shaped, with equal lobes; berry 4-celled but 2-seeded= Symphoricarpos.

\section{Distribtjtion of Genera}

Diervilla trifida (Bush-honeysuckle) ISSP. It occurs in dry or rocky woods.

Linnaea borealis (Twin-flower) ANESP. It has rounded, obscurely crenate leaves, purplish, fragrant flowers and occurs in cold woods.

Lonicera (Honeysuckle) NESPW. $11 \mathrm{sp}$. Of the erect species the Blue Fly-honeysuckle ( $L$. cocrulea) has the two bluish-black fruits united to the top; Black Twinberry ( $L$. involucrata) has leafy bracts under the two separate black berries. Both the above species are widely distributed.

Sambucus (Elder) ESPW. 4. sp. Oi the two eastern species the Red-berried Elder ( $S$. racemosa) has a pyramidal inflorescence and red berries, while the Purple-berried Elder (S. canadensis) has a flat-topped inflorescence and purple or black berries. Of the two western species the Black-berried Elder (S. melanocarpa) has a pyramidal inflorescence and black berries, while the Wlax-berried Elder (S. glauca) has a flat-topped inflorescence and glaucous fruit.

Symphoricarpos (Snowberry; Wolfberry) ESPW. 4 sp.

Triosteum (Horse-gentian) ES. 2 sp. Tinker's Weed ( $T$. perfoliatum) has the lower leaves united at the base and clasping the stem. It occurs only in southern Ontario; both species are found in woods.

Viburnum (Arrow-wood) NESPW. $8 \mathrm{sp.} \mathrm{In} \mathrm{the} \mathrm{Hobble} \mathrm{Bush} \mathrm{(} V$. alnifolium) the branches root at the tip, the leaves are crbicular, the outer flowers are large and neuter and the fruit when ripe is black. It is an eastern species. The High-bush Cranberry (V. Opulus) has palmately lobed leaves, large neuter outer flowers, and bright-red fruit. It is widely distributed.

\section{RUBIACEAE}

1. Shrubs with the flowers in dense globular heads=Cephalanthus.

Herbs with the flowers not in heads.

2. Creeping plants with evergreen leaves and flowers in pairs; ovary 4-celled; fruit red, fleshy, consisting of the 2 united ovaries=Mitchella.

Ovary 2-celled; fruit not fleshy. . 
3. Tufted plants with opposite leaves; fruit a capsule with several seeds=Houstonia.

Plants with leaves in apparent whorls; fruit a schizocarp, separating into two segments = Galium.

\section{Distribution of Genfra} ffowers.

Cephalanthus occidentalis (Button-bush) ES. It grows in wet ground and has white

Galium (Bedstraw) ANESPIV. 16 sp. Sweet-scented Bedstraw (G. triflomum) is a perennial species with leaves in sixes, flowers mostly in groups of three, and hooked fruits. It occurs in woods across Canada and becomes fragrant on drying. Northern Bedstraw ( $G$. boreale) with leaves in fours and white flowers is the only species found on the prairie.

Houstonia (Bluets) ESP. $4 \mathrm{sp}$. One-flowered Bluets (H. coerulea) has a single flower with salverform corolla on the peduncle; Fringed Bluets (H. ciliolata) has a fringe of hairs on the edge of the leaf and a funnelform corolla. Both are eastern species.

Mitchella repens (Partridge-berry) ES. The inner side of the white corolla-lobes is bearded; it occurs in woods and has an edible fruit.

\section{CUCURBITACEAE}

Corolla of the staminate flowers 6-lobed; fruit bursting irregularly at the top, 4seeded $=$ Echinocystis.

Corolla of the staminate Howers 5-lobed; fruit indehiscent, 1-seeded=Sicyos.

\section{Distribution of Genera}

Echinocystis (Balsam-apple) ESPW. 2 sp. Wild Balsam-apple (E. lobata) is an annual, found in the eastern and prairie regions, while Old Man Root (E. oregana) is a perennial with a thick fleshy root and is confined to the West.

Sicyos angulatus (One-seeded Bur-cucumber) ES. It is an annual.

\section{CAMPANULACEAE}

Flowers all alike; corolla mostly bell-shaped; capsule usually top-shaped=Campanula.

Annual plants with flowers of two kınds; corolla in the earlier cleistogamous flowers undeveloped, in the later flowers rotate; capsule prismatic or cylindrical=Specularia.

\section{Distribijtion of Genera}

Campanula (Bellflower) ANESPW. 9 sp. Tall Bellflower (C. americana) is an annual species with the flowers in a spilke and rotate corolla and occurs only in the east. White Bellflower (C. aparinoides) is perennial, with a rough straggling stem, narrow leaves and nearly white corolla; it occurs in wet ground in the east. The Harebell ( $C$. rotundifolia) is a perennial with broadly cordate or ovate leaves, linear stem-leaves, and blue corolla. It occurs in rocky places or dry ground and is widely distributed.

Specularia perfoliata (Venus's Looking-glass) ESW. The leaves have a clasping base and the flowers are blue or violet. It occurs in dry open ground.

\section{LOBELIACEAE}

Annual piants with axillary, sessile flowers; corolla bilabiate, but with entire tube; capsule 1-celled when mature, with parietal placentation=Bolelia.

Mostly perennial plants; corolla bilabiate, its tube split down one side; capsule 2celled = Lsobelia.

\section{Distribution of Genera}

Bolelia elegans (Bolelia) W. It occurs in water and has a blue corolla with white and yellow centre.

Lobelia (Lobelia) NESPW. 6 sp. Water Lobelia (L. Dortmanna) has radical, terete, hollow leaves and a raceme of blue flowers It occurs in water. Cardinal-flower $(L$. cardinalis) is perennial, with short offsets and a bright red corolla; it occurs in moist soil. Indian Tobacco (L. inflata) is an annual species with pale-blue flowers in which the capsule becomes inflated at maturity. It occurs in dry soil and is widely distributed. 


\section{VALERIANACEAE}

Annual, dichotomously branched plants with simple leaves; calyx-teeth small or inconspicuous; corolla usually spurred; fruit 3-celled but only one develops a seed=Valerianella.

Perennial plants with strong-smelling roots; upper leaves mostly pinnately lobed; calyx-lobes at first inrolled but expanding and plumose in fruit; the fruit is 1-celled= Valeriana.

\section{Distribltion of GeNera}

Valeriana (Valerian) ANESW. 8 sp. Edible Valerian (V. edulis) has a fleshy carrotlike root, leaves with parallel veins and yellowish corolla; it occurs in wet open ground in southern Ontario.

Valerianel!n (Corn-salad) W. $4 \mathrm{sp}$. Spurless Corn-salad (V. anomala) has a white corolla devoid of a spur, and a winged fruit. It occurs in moist open places. 


\title{
CHAP'TER XXII
}

\section{SYMPETALOUS DICOTYLEDONS}

\author{
COMPOSITAE
}

1. Flowers inconspicuous, unisexual, both kinds occurring in the same head, or the head compased of one kind of flowers onjy in which ease the pistillate head is bur-like; receptacle chaffy; the corolla of the pistillate flower is usually rudimentary or absent; stamens 5, separate; there is no pappus=AMBROSIACEAE (p. 73).

Anthers united to form a tube.

2. Plants with milky juice; all the flowers in the head are zygomorphic and bisexual; corolla strap-shaped, with 5 teeth $=$ CICHORIACEAE (p. 73).

Heads either discoid with all the flowers actinomorphic, or radiate with the central flowers actinomorphic and the ray flowers zygomorphic and pistillate or neuter $=$ CARDUACEAE (p. 74).

\section{AMBROSIACEAE}

1. Staminate and pistillate flowers in the same head................. 2 Staminate and pistillate flowers in different lieads, the pistillate flowers being enclosed

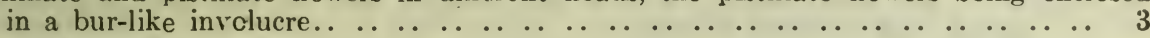

2. Annual plants with naked inflorescence: corolla of the pistillate flowers rudimentary or none $=$ Cyclachaena.

Perennial plants with leafy bracts among the heads; the pistillate flowers have a corolla = Iva.

3. Bracts of the staminate head separate. and in 1-3 series; pistillate heads containing 2 flowers: involucre covered witn hooked spines $=$ Xanthium.

Bracts of the staminate head united; prickles on the involucre not hooked.. .. . . 4

4. Pistillate heads 1-flowered with a single series of tubercles or prickles on the involucre =Ambrosia.

Pistillate heads 1 -4-flowered, with several rows of spines on the involucre $=$ Franseria

\section{Distribution of Genera}

Ambrosia (Ragweed) ESPW. 3 sp. Great Ragweed (A. trifida) is an annual with opposite, mostly 3-lobed leaves; Tansy-leaved Ragweed (A. artemisiaefolia) is an annual with leaves twice pinnately lobed; Prairie Ragweed (A. psilostachya) is a perennial species with pinnately lobed leaves occurring on the prairie.

Cyclachaena xanthiifolia (Burweed Marsh-elder) EP. It occurs in moist soil.

Franseria (Bur-ragweed) PW. $4 \mathrm{sp}$. Annual Bur-ragweed (F. acanthicarpa) is the only species found on the prairie. The other species, known as Sand-bur, are perennial and occur on the sea coast.

Iva axillaris (Poverty-weed) PW. It has simple leaves, opposite below but alternate above, and heads mostly solitary in their axils; it occurs in saline soil.

Xanthium (Clotbur: Cocklebur) ESPIV. $6 \mathrm{sp.} \mathrm{They} \mathrm{are} \mathrm{all} \mathrm{annual} \mathrm{species.}$

\section{CICHORIACEAE}

1. Plants with the leaves all basal or with a single leaf on the upper part of the stem;

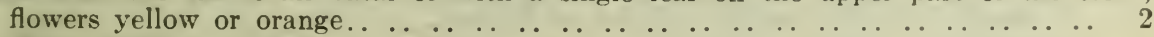

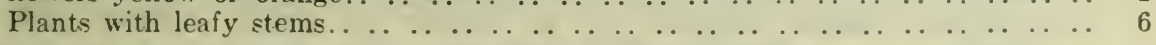

2. Annual plants with solitary heads.. . . . . . . . . . . . . . . . . . . . . . 3

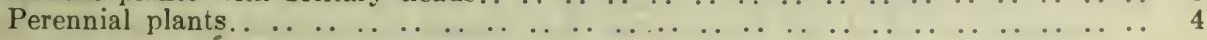

3. Bracts of the involucre in two series, reflexed in fruit; the pappus consists of an outer series of 5 scales and an inner series of 10 or more bristles $=$ Krigia.

Outer bracts of the involucre very short; the pappus consists of 5 awn-tipped scales $=$ Microseris. 
4. Stem branched above, bearing 1-2 clasping leaves; bracts reflexed in fruit; flowers orange; the pappus consists of both scales and bristles = Adopogon.

Leaves all basal; heads solitary on the scape; flowers yellow or purple.. .. .. . . 5

5. Leaves narrow; bracts imbricated; flowers yellow, generally turning purple; pappushairs simple, white $=$ Agoseris

Root spindle-shaped; bracts in 2 or 3 series; flowers yellow; pappus tawny, consisting of barbellate bristles $=$ Apargidium .

Plants with a taproot and hollow scape; principal bracts equal with a series of shorter ones at the base; flowers yellow; achene with a slender beak; pappus white, consisting of simple bristles = Taraxacum.

6. Upper leaves linear or scale-like; flowers pink. . . . . . . . . . . . . . . . . 7

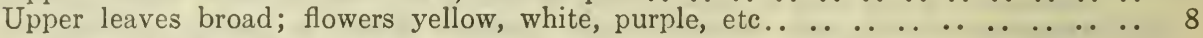

7. Bracts equal with a few small ones at the base; pappus composed of simple bristles, sometimes brown in colour = Lygodesmia.

Principal bracts in one series, 5 in number, with a few small ones at the base; flowers in the head 5 in number; pappus-bristles plumose $=$ Stephanomeria.

8. Perennial herbs with spindle-shaped roots; flowers yellow; pappus-hairs white, plumose, with broader bases = Ptilophora.

Pappus-hairs white or brown, simple.. . . . . . . . . . . . . . . . . . . . . 9

9. Mostly biennial plants with imbricated bracts; flowers yellow or bluish; achenes flattened, narrowed at the top or prolonged into a beak = Lactuca.

Perennial plants; achenes cylindrical, not beaked.. . . . . . . . . . . . . . . . . 10

10. Bracts in one series, equal, with ai few smaller ones at the base; flowers yellow; pappus-hairs white $=$ Crepis.

Bracts in 1-3 series; flowers mostly yellow; achenes truncate at the top; pappus-hairs brownish = Hieracium

Flower-heads drooping, with the principal bracts in 1 or 2 series and subequal; flowers white to purple; pappus-hairs brownish $=$ Prenanthes .

\section{Distribution of Genera}

Adopogon virginicus (Virginian Goat's-beard) ES. It occurs in woods. Agoseris (Goat's Chicory) PW. 18 sp.

Apargidium boreale (Tawny Dandelion) W. It occurs in wet situations.

Crepis (Hawksbeard) ANPW. $10 \mathrm{sp.}$

Hieracium (Hawkweed) ESPW. 16 sp.

Krigia virginica (Dwarf Dandelion) ES. It occurs in dry soil.

Lactuca (Lettuce) ESPW. $7 \mathrm{sp.} \mathrm{Large-fiowered} \mathrm{Blue} \mathrm{Lettuce} \mathrm{(L.} \mathrm{pulchella)} \mathrm{is} \mathrm{a} \mathrm{peren-}$ nial with heads half an inch or more in diameter, blue flowers and white pappus. Tall Blue Lettuce (L. spicata) is annual or biennial with heads less than $\frac{1}{4}$ inch in diameter, blue or white fiowers and brown pappus. Both species occur in moist soil.

Lygodesmia (Skeleton-weed) PW. 3 sp. Purple Skeleton-weed (L. juncea) is a perennial with greatly reduced subulate leaves found on the prairie.

Microseris Bigelovii (Annual Hawkbit) W.

Prenanthes (Rattlesnake-root) NESPW. 8 sp. Glaucous Rattlesnake-root ( $P$. racemosa) has the heads nearly erect, hairy bracts, and purplish flowers. It occurs in moist open places.

Ptilophora (Hill-lettuce) W. 3 sp.

Stephanomeria tenuifolia (Desert Pink) W. It is a perennial.

Taraxacum (Dandelion) APW. $3 \mathrm{sp}$.

\section{CARDUACEAE}

1. Flower-heads mostly inconspicuous, or with scarious coloured bracts; marginal flowers usually pistillate; corolla tubular or filiform. . . . . . . . . . . . . . . 2

Flower-heads brightly coloured; all the flowers are usually bisexual with tubular corolla.. . . . . . . . . . . . . . . . . . . . . . . . . . . . . . . . .

Flower-heads brightly coloured, consisting of a central series of disk flowers and a marginal series of ray flowers; the disk flowers are bisexual and the ray flowers pistillate or neuter; (sometimes the ray flowers are short or absent altogether).. 16

2. Leaves entire; bracts generally scarious or coloured; receptacle naked; pappus composed of hairs.. $\ldots \ldots \ldots \ldots \ldots$

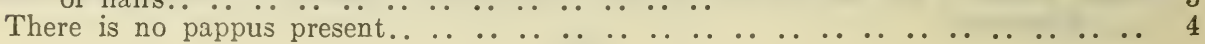


3. Perennial woolly plants with leafy stems; bracts pearly white; some of the heads are composed entircly of apparently bisexual but functionally staminate flowers, while other heads have these apparently bisexual but really staminate flowers in the centre only, with the marginal flowers pistillate = Anaphalis.

Perennial woolly plants, stoloniferous, usually with heads in clusters; all the heads on the same plant are either apparently bisexual but functionally staminate, or are pistillate; corolla of the pistillate flowers filiform; pappus-hairs in the sterile flowers usually club-shaped = Antennaria.

Annual, biennial or perennial woolly plants; central flowers bisexual with tubular corolla, marginal flowers pistillate with filiform corolla; the corolla is whitish or yellowish in colour = Gnaphalium.

4. Perennial plants, with broad basal leaves which are woolly below; heads grouped in a panicle; bracts of the involucre green; flowers white, the central ones apparently biscxual but functionally staminate, the marginal ones pistillate; fruits clavate, glandular = Adenocaulon.

Strongly scented plants with narrow or divided alternate leaves; heads small and numerous; the flowers in the same head may be apparently bisexual but really staminate at the centre and pistillate at the margin, or truly bisexual at the centre and pistillate at the margin, or all the flowers may be truly bisexual; fruit ellipsoidal = Artemisia .

Annual woolly plants with the leaves mostly opposite; outer flowers in the head pistillate, each with a chaffy bract enclosing the fruit $=$ Psilocarphus.

5. Leaves pinnately divided; pappus absent or composed of scales........... 6

Pappus composed of simple hairs.. . . . . . . . . . . . . . . . . . . . . 7

Corolla mostly purple; pappus-hairs plumose or feathery.. $\ldots \ldots \ldots \ldots$

6. Biennial plants with white or pink corolla; pappus composed of 4-14 hyaline scales $=$ Chaenactis.

Perennial plants; bracts subequal, coloured, with scarious margins; corolla yellow; pappus-scales $10-20$, scarcely visible $=$ Hymenopappus.

Perennial plants with opposite leaves; inner bracts of the involucre united into a cup; corolla yellow; receptacle with chaffy scales; pappus composed of two small teeth $=$ Thelesperma.

7. Shrubs or undershrubs with narrow leaves, mostly covered with white hairs; corolla yellow. . . . . . . . . . . . ..................... 8

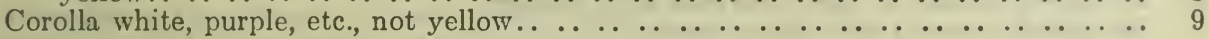

8. Bracts numerous; there are 5 or more flowers in each head=Chrysothamnus.

There are 4 bracts and 4 flowers in each head=Tetradymia.

9. Lower leaves opposite or whorled; fruit with 5 angles.. . . . . . . . . . . . 10

Leaves mostly alternate; receptacle naked.. $\ldots \ldots \ldots \ldots \ldots \ldots$

10. Bracts numerous; there are usually 5 or more flowers in each head=Eupatorium.

Stem twining; each head consists of 4 bracts and 4 whitish flowers=Mikania.

11. Annual plants with the principal bracts in one series; corolla whitish; marginal flowers pistillate $=$ Erechtites.

Perennial plants with all the flowers bisexual. . . . . . . . . . . . . . . . 12

12. Principal bracts in one series; heads with 5 -10 white or cream-coloured flowers.. .. 13

Bracts in several series; heads with numerous white or pinkish flowers........ 14

13. Bracts $8-10$ in number; heads with about 10 flowers; corolla cream-coloured=Luina.

Principal bracts 5 , equal; heads with 5 flowers; corolla white; the receptacle has a fleshy projection in the centre=Mesadenia.

14. Pappus-hairs white, in a single series=Brickellia.

Corolla usually purple; pappus-hairs purple, in two series, the outer series being much shorter than the inner=Vernonia.

15. Leaves and bracts usually spiny; receptacle bristly $=C$ irsium

Perennial plants with tubers and narrow entire leaves; heads grouped in a raceme or spike; receptacle naked=Liatris.

Perennial plants with bristly receptacle; pappus double, the outer series composed of short rigid bristles and the inner of plumose bristles united at the base=Saussurea.

16. Ray flowers yellow. ............................. 17

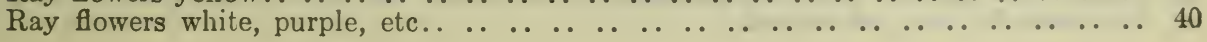


17. Pappus none, or a short crown . . . . . . . . . . . . . . . . . . . . . . . $\ldots 18$

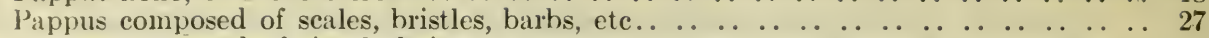

Pappus composed of simple hairs.. $\ldots \ldots \ldots \ldots \ldots \ldots$

18. Receptacle naked. . . . . . . . . . . . . . . . . . . . . . . . . . . . 19

Receptacle with chaffy scales.. . . . . . . . . . . . . . . . . . . . . . . . . . . . . .

19. Leaves opposite; heads solitary=Jaumea.

Strongly scented plants with alternate, pinnately divided leaves and numerous heads; central flowers bisexual, marginal pistillate=Tanacetum.

20. Ray flowers neuter... . . . . . . . . . . . . . . . . . . . . . . . . . . . 21

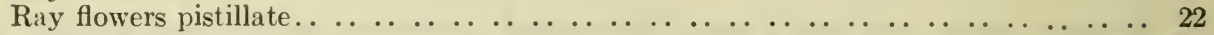

21. Lower or all the leaves opposite; bracts in two series, united at the base; fruit flat= C'orcopsis.

Rough or hispid perennial plants with alternate leaves; disk-flowers mostly purple; receptacle convex to cylindrical; fruit 4 -angled $=R u d b e c k i a$.

22. Glandular annuals; disk-flowers bisexual; bracts enclosing the outer fruits... . . 23

Perennial plants; the bracts do not enclose the outer fruits.. . . . . . . . . . . . . 24

23. Leaves opposite, linear; bracts 4-5; scales of receptacle united to form a cup= Hemizonella.

Viscid plants with alternate leaves; bracts in a single series=Madia.

24. Disk-flowers apparently bisexual but functionally staminate only...... . . . . . 25

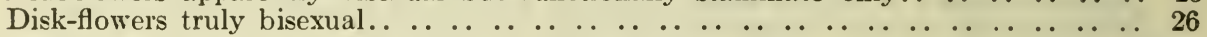

25. Viscid plants with opposite leaves; outer bracts large, 5 in number, inner bracts smaller; rays small or sometimes absent $=$ Polymnia.

Plants with resinous juice and opposite, whorled, or basal leaves; heads on long peduncles; fruit winged, notched=Silphium.

26. The roots contain a balsamic resin; leaves basal; bracts in several series=Balsamorrhiza.

Leaves opposite, 3-ribbed; heads on long peduncles; corolla of the ray-flowers persistent on the fruit=Heliopsis.

27. Receptacle naked or rarely covered with bristles. . . . . . . . . . . . . . . 28

Receptacle covered with chaffy scales. . . . . . . . . . . . . . . . . . . . . 32

28. Annual plants with opposite leaves; receptacle subulate to conical; pappus a crown of scales=Baeria.

Perennial plants with alternate leaves; heads solitary on long peduncles; disk-flowers purple, ray-flowers purple at the base and neuter; receptacle bristly; pappus composed of hyaline chaffy scales=Gaillardia.

Leaves alternate; ray-flowers pistillate. . . . . . . . . . . . . . . . . . . . . . . 29

29. Perennial plants with punctate leaves; fruit hairy . . . . . . . . . . . . . . 30

Leaves not punctate; fruit glabrous... . . . . . . . . . . . . . . . . . . . . . 31

30. Leaves entire or pinnatifid with narrow lobes; heads on long peduncles; bracts in 2 o: more series; receptacle conical to convex; pappus composed of about 5 hyaline scales =Actinea.

Leaves linear and entire; flower-heads small and numerous, with few flowers in each head; fruit crowned with scales=Gutierrezia.

Leaves lançeolate, usually decurrent; heads on long peduncles; bracts few, reflexed; pappus composed of 4-8 scarious scales=Helenium.

31. Perennial, tufted, woolly plants; heads on long peduncles; bracts in one series or in two equal series; pappus composed of 4-12 hyaline scales=Eriophyllum.

Biennial or perennial plants with spinulose-toothed leaves; heads solitary on leafy branches; bracts imbricated and mostly gummy; pappus composed of a few deciduous bristles = Grindelia.

32. Perennial plants with taproot and resinous juice; leaves alternate, simple, and pinnately veined; ray-flowers pistillate; fruit with $3-4$ angles; pappus composed of scales= Wyethia.

Ray-flowers neuter. . . . . . . . . . . . . . . . . . . . . . . . . . . . . . . . . . 33

33. The pappus consists of $2-6$ barbed awns... . . . . . . . . . . . . . . . . . . . 34

Pappus-scales, etc., not barbed. . . . . . . . . . . . . . . . . . . . 35 
34. Mostly annual plants with the lower or all the leaves opposite; bracts in two series, the outer foliaceous=Bidens.

Perennial aquatic plants with finely divided submerged leaves and simple aerial leaves; flowers solitary $=$ Megalodonta.

35. Mostly perennial, sometimes annual plants with opposite or alternate, simple leaves: heads large, on long peduncles; receptacle flat; fruit more or less 4-angled and compressed; the pappus consists of two deciduous scales=Helianthus.

Perennial plants with taproot; leaves usually opposite and 3-ribbed; the pappus is composed of scales between the 2 awns= Helianthella.

Perennial plants with alternate pinnately divided leaves; heads on long peduncles; receptacle convex or cylindrical; corolla of ray-flowers spreading or drooping; fruit flattened; pappus composed of 1-2 teeth=Ratibida.

36. Lower or all the leaves opposite; bracts equal, in one or two series; pappus mostly a single series of capillary bristles=Arnica.

Leaves alternate or basal; disk-flowers yellow; receptacle mostly naked. . . . . . . 37

37. Bracts equal in length. or the principal bracts in one series with a few outer ones.. 38

Perennial plants with the bracts in several series.. $\ldots \ldots \ldots \ldots$

35. Annual plants with simple leaves; heads solitary, terminal; pappus composed of one row of deciduous barbed bristles, none on the ray-flower's=Crocidium.

Mostly perennial plants; heads rarely solitary; principal bracts in one series with a few outer ones=Senecio.

39. Tufted plants with sessile, hairy, mostly entire leaves; pappus double, the outer series composed of small scales or bristles, the inner of scabrous bristles; fruit flattened, hairy $=$ Chrysopsis.

Plants frequently dwarf; ray-flowers sometimes short and sterile, or absent; pappusbristles sometimes unequal, white, yellow, or reddish brown in colour=Haplopappus. Leaves simple; heads small and numerous; pappus-hairs in one or two series=Solidago.

40. Bracts imbricated; pappus absent or in the form of a crown of short teeth, etc.. .. 41 Leaves alternate or basal; pappus composed of simple hairs. . . . . . . . . . . 44 Annual plants with chaffy receptacle and a pappus of plumose hairs.. . . . . . . 51

41. Perennial plants; receptacle with chaffy scales.................... 42

Annual or perennial plants; receptacle naked. . . . . . . . . . . . . . . 43

42. Roots thick and black with pungent taste; leaves simple; heads on long peduncles; both disk- and ray-flowers are purple, the latter being neuter; receptacle conical; fruit 4 -sided=Brauneria.

Leaves usually divided; heads grouped in a corymb; disk-flowers yellowish; ray-flowers pistillate $=$ Achillea .

43. Strong-scented annual plants with divided leaves and heads on long peduncles; rayflowers white; recentacle conical to ovoid; fruit $3-\mathbf{a}$ ribbed $=$ Matricaria.

Perennial plants with solitary heads; receptacle flat to hemispherical; fruit 5-10-ribbed $=$ Chrysanthemum.

44. Perennial plants with leafy stems; leaves entire; corolla white or violet; pappus double, tawny in colour=Diplopappus.

Pappus single. . . . . . . . . . . . . . . . . . . . . . . . . . . . . . .

45. Annual plants with narrow leaves; heads small and numerous; ray-flowers short, inconspicuous. . . . . . . . . . . . . . . . . . . . . . . . . . . . . . . . . . . . . . . . . . . 46

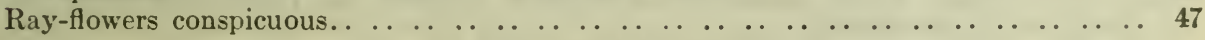

46. Bracts nearly equal; flowers purplish in colour; fruit narrow=Brachyactis.

Bracts unequal; flowers white; corolla of the disk-flowers 4-lobed; fruit flattened= Leptilon.

47. Plants with rhizomes, sc:lly peduncles and basal, arrow-shaped to reniform leaves which appear after the flowers and are woolly beneath; heads grouped on the scape in a racemose manner; bracts in one series, equal; some of the flowers are apparently bisexual but are functionally staminate only=Petasites.

Stems mostly leafy, with the flower-heads appearing after the leaves; bracts generally unequal. . . . . . . . . . . . . . . . . . . . . . . . . . . . 48 
48. Perennial plants with sessile, entire leaves; bracts imbricated; ray-flowers 4-5; all the flowers are whitish $=$ Sericocarpus.

Ray flowers more than 5 in number....................... . . . .

49. Bracts in 1 or 2 series, subequal; ray-flowers generally numerous, of ten in more than one row, with narrow corolla; disk-flowers yellow; fruit flat, 2-nerved=Erigeron.

Bracts imbricated; corolla of ray-flowers ligulate................ 50

50. Mostly perennial plants with numerous ray-flowers; disk-flowers yellow but changing to red, brown, or purple $=$ Aster.

Annual or biennial plants with tap roots; leaves simple or pinnately divided; diskflowers yellow, changing to red or brown; ray-flowers violet to purple= Machaeranthera.

Tufted biennial or perennial plants; leaves mostly basal, linear or spatulate, and entire $=$ Townsendia.

51. Leaves entire; heads with 3-6 fertile ray-flowers and 7-12 disk-flowers some of which are sterile; both kinds of flowers are white=Blcpharipappus.

Lower leaves lobed, upper entire; ray-flowers white, disk-flowers yellow; the achenes of the ray-flowers are enclosed by the bracts and have no pappus=Layia.

\section{Distribution of Genera}

Achillea (Yarrow) ANEPW. 8 sp.

Actinea (Dotted Rayweed) SP. 5 sp. Eastern Dotted Rayweed (A. herbacea) is a tufted perennial with basal leaves and single heads of yellow flowers; it occurs only in southern Ontario.

Adenocaulon bicolor (Club-fruit; Silver-green) W. It occurs in damp woods.

Anaphalis (Everlasting) NEW. $3 \mathrm{sp.}$

Antennaria (Cat's Foot: Everlasting) ANEPW. 36 p.

Arnica (Leopard's Bane; Arnica) ANEPW. $33 \mathrm{sp.} \mathrm{Ray-flowers} \mathrm{are} \mathrm{absent} \mathrm{in} \mathrm{Rayless}$ Arnica (A. Parryi).

Artemisia (Wormwood; Mugwort; Sage-brush) ANESPW. 44 sp. Common Sage-brush (1. tridentata) is a shrub several feet high, covered with silvery hairs, with 3 teeth at the end of the wedge-shaped leaves. It is confined to the dry belt of British Columbia.

Aster (Aster) ANESPW. $84 \mathrm{sp.}$

Baeria maritima (Gold-fields; Sea Baeria) W. It is confined to the sea-coast.

Balsamorrhiza (Balsam-root) PW. 3 sp. Arrow-leaved Balsam-root (B. sagittata) has woolly leaves and is the only species found on the prairie.

Bidens (Beggar-ticks; Bur-marigold) NESPW. $14 \mathrm{sp}$. One of the most widely distributed species is Nodding Bur-marigold (B. cernua) with simple leaves and drooping heads. The species all occur in wet ground.

Blepharipappus scaber (Fringe-cup) W. It is confined to the dry belt of British Columbia.

Brachyactis angusta (Rayless Aster) NEP. It occurs on saline soil.

Brauneria angustifolia (Purple Cone-flower) P. It occurs on dry soil.

Brickellia (Thoroughwort) W. 2 sp.

Chaenactis Douglasii (Moming Brides) W. It occurs in dry situations.

Chrysanthemum (Chrysanthemum) A. $3 \mathrm{sp.}$

Chrysopsis (Golden Aster) PW. 5 sp.

Chrysothamnus (Rabbit-brush) PW. 3 sp. Prairie Rabbit-brush (C. frigidus) is the only species found on the prairie.

Cirsium (Thistle) NESPW. $15 \mathrm{sp.} \mathrm{Many} \mathrm{of} \mathrm{the} \mathrm{species} \mathrm{are} \mathrm{biennial.}$

Coreopsis (Tickseed) ESPW. $6 \mathrm{sp.} \mathrm{Two} \mathrm{species} \mathrm{occur} \mathrm{in} \mathrm{southern} \mathrm{Ontario,} \mathrm{namely,}$ Lance-leaved Tickseed (C. lanceolata) with simple leaves and Tall Tickseed (C. tripteris) with the lower leaves divided. Of the prairie species Garden Tickseed (C. tinctoria) is annual and has brown or partly brown ray-flowers while Stiff Tickseed (C. palmata) is perennial and has bright-yellow ray-flowers.

Crocidium multicaule (Single-headed Groundsel) W.

Diplopappus (Double-crowned Aster) EPW. 2 sp.

Erechtites hieracifolia (White Fireweed) ESP. It is one of the first species to occupy burnt ground.

Erigeron (Fleabane) ANESPW. 47 sp.

Eriophyllum (Woolly Sunflower) W. 2 sp.

Eupatorium (Thoroughwort) ESPW. 6 sp. Of the eastern species with opposite leaves and white flowers Boneset ( $E$. perfoliatum) occurs in marshes and has long pointed leaves connate at the base, while White Snakeroot (E. urticaefolium) occurs in woods and has stalked ovate leaves.

Gaillardia aristata (Blanket-flower) PW. It has punctate leaves. 
Gnaphalium (Cudweed; Everlasting) ANESPW. 13 sp. Clammy Everlasting (G. dccurrens) is an annual or biennial species with a fragrant odour, viscid glands and decurrent leaves.

Grindelia (Gum-weed) PW. 8 sp.

Gutierrezia (Broom-weed) P. $2 \mathrm{sp.}$

Haplopappus (Iron-plant) PW. $12 \mathrm{sp.} \mathrm{In} \mathrm{some} \mathrm{species} \mathrm{the} \mathrm{ray-flowers} \mathrm{are} \mathrm{very} \mathrm{short}$ or absent.

Helcnium (Sneezeweed) ESPIV. 3 sp. Eastern Sncezeweed ( $H$.autumnale) is the only species found in the east; it occurs in wet ground and is considered poisonous.

Helianthella Douglasii (Flat-seeded Sunflower) W.

Helianthus (Sunflower) ESPIV. $19 \mathrm{sp.}$

Heliopsis (Ox-eye) ESPIW. 2 sp.

Hemizonella (Opposite-leaved Tarweed) W. 2 sp.

Hymenopappus filifolius (Prairie-everlasting) P.

Jaumea carnosa (Bald Sunflower) W. It occurs in salt marshes on the coast.

Layia glandulosa (White-rayed Tarweed) W. It occurs in sandy places.

Leptilon canadense (Horseweed) NESW. It occurs mostly as a weed in fields and waste ground.

Liatris (Blazing Star; Button-snakeroot) ESP. 6 sp.

Luina hypoleuca (Creamy Ragwort) W. It occurs on mountain cliffs.

Machaeranthera (Aster) PIW. $2 \mathrm{sp.} \mathrm{Tansy-leaved} \mathrm{Aster} \mathrm{(M.tanacetifolia)} \mathrm{is} \mathrm{an} \mathrm{annual}$ with pinnately lobed or divided leaves and is confined to the prairie. Biennial Aster ( $M$. canescens) is a biennial with simple leaves.

Madia (Tarweed) PW. $6 \mathrm{sp}$. Clustered Tarweed (M. glomerata) has linear leaves and flower-heads in a compact cluster with ray-flowers sometimes absent; it is the only species found on the prairie.

Matricaria (Chamomile) ANEW. 2 sp. Pineapple-weed ( $M$. suaveolens) is a sweetscented plant devoid of ray-flowers and with a four-lobed corolla on the disk-flowers. It occurs in the western region but is also found elsewhere as an introduced weed.

Megalodonta Beckii (Water Marigold) ES.

Mesadcnia (Indian Plantain) S. 2 sp. Pale Indian Plantain (M. atriplicifolia) has palmately lobed leaves and occurs in woods while Tuberous Indian Plantain ( $M$. tuberosa) has ovate usually entire leaves and occurs in wet places.

Mikania scandens (Climbing Hempweed) S. It occurs in swampy ground.

Petasites (Sweet Coltsfoot) NEPW. $7 \mathrm{sp.} \mathrm{Of} \mathrm{the} \mathrm{three} \mathrm{eastern} \mathrm{species} \mathrm{Arrow-leaved}$ Swect Coltsfoot ( $P$. sagittata) has arrow-shaped leaves which are slightly toothed or wavy on the margin. All the species occur on wet ground.

Polymnia canadensis (Leafcup) S. It occurs in damp shaded places.

Psilocarphus (Woolly Bladder-fruit) W. $2 \mathrm{sp.}$

Ratibida (Cone-flower) SPIY. $2 \mathrm{sp.} \mathrm{Gray-headed} \mathrm{Cone-flower} \mathrm{(} R$. pinnata) has a short fruiting head and is confined to southern Ontario, while Prairie Cone-flower ( $R$. columnaris) has brownish-yellow ray-flowers and a long fruiting head; it occurs on the prairie and B.C.

Rudbeckia (Cone-flower) ESPW. $3 \mathrm{sp.} \mathrm{Of} \mathrm{the} \mathrm{two} \mathrm{eastern} \mathrm{species} \mathrm{Black-eyed} \mathrm{Susan}$ ( $R$. hirta) is a hispid biennial with simple leaves and purple disk-flowers; while Tall Coneflower ( $R$. laciniata) is a glabrous perennial with divided leaves and a conical fruit-head.

Saussurea (Saw-wort) APW. 2 sp.

Senecio (Ragwort; Groundsel; Squaw-weed) ANESPW. 42 sp. Marsh Groundsel (S. palustris) is an annual with hollow stem and the upper leaves somewhat clasping; its distribution is mainly in northern swampy places.

Sericocarpus rigidus (White-topped Aster) W. It occurs in dry ground.

Silphium (Rosin-weed; Compass-plant) S. $3 \mathrm{sp.} \mathrm{Cup-plant} \mathrm{(S.} \mathrm{perfoliatum)} \mathrm{has} \mathrm{the}$ upper leaves connate-perfoliate and occurs in moist soil; Whorled Rosin-weed (S. trifoliatum) has the middle leaves in whorls of 3 or 4 and occurs in woods; Dock-leaved Rosinweed (S. terebinthinaceum) has alternate, mostly basal leaves which are cordate at the base.

Solidago (Golden Rod) NESPW. $51 \mathrm{sp.} \mathrm{White} \mathrm{Golden-Rod} \mathrm{(S.} \mathrm{bicolor)} \mathrm{has} \mathrm{white}$ ray-flowers; it occurs in dry soil in the East.

Tanacetum (Tansy) NEW. 2 sp.

Tetradymia canescens (Four-flowered Rabbit-brush) W. It occurs in dry soil.

Thelesperma marginatum (Narrow-leaved Bur-marigold) P. It occurs on dry soil.

Townsendia (Townsendia) PW. $2 \mathrm{sp.} \mathrm{Dwarf} \mathrm{Townsendia} \mathrm{(T.} \mathrm{exscapa)} \mathrm{is} \mathrm{a} \mathrm{short-}$ stemmed perennial confined tu dry soil on the prairie; Biennial Townsendia (T. Parryi) is a biennial species found on the western mountains.

Vernonia (Iron-weed) SP. $4 \mathrm{sp.} \mathrm{Prairie} \mathrm{Iron-weed} \mathrm{(V.} \mathrm{corymbosa)} \mathrm{is} \mathrm{the} \mathrm{only} \mathrm{species}$ found on the prairie.

Wyethia amplexicaulis (Mule-ears) W. It occurs in moist ground. 


\section{CHAPTER XXIII}

\section{SPECIAL GROUPS}

Sometimes the name of a plant can be more readily determined from a consideration of its manner of growth. The number of Canadian genera belonging to some particular group is obviously much smaller than the total number of genera in the country; consequently the genus to which the plant belongs must be one of a comparatively small number. By excluding those already known to belong to a different genus the choice is still further restricted. The more important of these special groups are outlined below.

\section{CLIMBING PLANTS}

A. Root-climbers are exemplified by a species of Rhus and by Tecoma.

B. Twiners are exemplified by Celastrus, species of Lonicera, and Menispermum, all of which are shrubs. Among herbaceous twining species are Amphicappa, Calystegia, Cuscuta, Dioscorea, Glycine, Ipomoea, Mikania, species of Polygonum, and Strophostyles.

C. Leaf-climbers are found in Adlumia and species of Clematis.

D. Tendril-climbers are found in Echinocystis, Lathyrus, Parthenocissus, Sicyos, species of Smilax, Vicia, and species of Vitis.

E. Hook-climbers are exemplified by species of Galium, species of Polygonum, and species of Rubus.

\section{CARNIVOROUS PLANTS}

This group can usually be recognized by the peculiarities of the leaves. It comprises four genera, namely, Drosera, Pinguicula, Sarracenia, and Utricularia. 'The first three occur in swampy ground and the last usually in water.

\section{PARASITIC AND SAPROPHYTIC PLANTS}

A. Semi-parasites are green but derive part of their nourishment from other plants. This group is exemplified by Arceuthobium which grows on the branches of coniferous trees. Others, such as Castilleja, Euphrasia, Pedicularis, etc., are attached to the roots of the other plants but the semi-parasitic habit in this case is not so obvious.

B. Total parasites are devoid of green colouring matter. They are exemplified by the genus Cuscuta, which twines round the stems of other plants, and by the members of the family Orobanchaceae, which are root-parasites.

C. Saprophytes contain little or no green colouring matter and are found chiefly among decaying vegetation. They are exemplified by Bartonia which has some green colouring matter, Cephalanthera, Corallorrhiza, and by the family Monotropaceae, and one species of Pyrola.

\section{AQUATIC PLANTS}

There is no very hard and fast distinction between water-plants and plants growing in swamps. Various intermediate stages can be found between those which are entirely submerged and those in which the roots only are immersed. 
While the vast majority of plants belonging to this group occur in fresh water a few genera are found in the sea.

A. Plants without any differentiation into stem and leaf. This condition occurs in the two genera Lemna and Wolffia.

B. Plants found in the sea. This group includes Phyllospadix and Zostera.

C. Plants with all the leaves submerged. Examples of this group are Callitriche autumnalis, Ceratophyllum, Elodea, Eriocaulon, Littorella, Lobelia Dortmanna, Najas, Podostemon, species of Potamogeton, species of Ranunculus, Subularia, Utricularia, Vallisneria, and Zannichellia.

D. Plants with floating leaves occur in Brasenia, Caltha natans, Heteranthera, Limnobium, Nymphaea, Nymphoides, Nymphozanthus, Polygonum amphibium, species of Potamogeton, species of Sparganium.

E. Plants with some of the leaves submerged and some exposed to the air. This type occurs in species of Callitriche, Hippuris, Juncus militaris, Megalodonta, Myriophyllum, Nasturtium aquaticum, Proserpinaca, and Ranunculus delphinifolius.

F. Plants with the roots and lower part of the stem only immersed in water or mud. This group includes Acorus, Alisma, Asclepias incarnata, Calla, species of Caltha, species of Carex, Cicuta, Dianthera, Echinodorus, Elatine, Heleocharis, Eriophorum, Juncus effusus, Lilaea, Limosella, Lophotocarpus, Ludurgia, Lysimachia thyrsiflora, Menyanthes trifoliata, Nelumbo, Peltandra, Pontederia, Potentilla palustris, Rhynchospora, species of Rumex, species of Sagittaria, Saururus, species of Scirpus, Sium, species of Sparganium, Symplocarpus, Typha, species of Veronica, Xyris montana, and Zizania.

\section{TREES}

A. Cone-bearing trees. With the exception of Larix these are all evergreen and are dealt with in Chapter III.

B. Evergreen trees with broad leaves and fleshy fruits. Arbutus is the only example of this group.

C. Deciduous trees with opposite leaves. Included in this group are Acer, Fraxinus, and Gymnocladus.

D. Deciduous trees with alternate pinnately compound leaves. Examples are Carya and Juglans.

E. Deciduous trees with inconspicuous flowers, which are often unisexual and in catkins or dense clusters. In this group are included species of Alnus, species of Betula, Castanea, Fagus, Ostrya, Platanus, Populus, Quercus, species of Salix, and Ulmus.

F. Deciduous trees with showy flowers include Liriodendron, Nyssa, Prunus, and Tilia.

\section{SPINY PLANTS}

A. Plants with spiny leaves include Astragalus montanus, Cirsium, Juniperus communis, Mahonia, and Salsola Kali.

B. Plants with bristles or prickles on the stem are included in the genera Echinopanax, Mammillaria, Opuntia, species of Ribes, Rosa, species of Rubus, species of Smilax and Xanthoxylum.

C. Plants with long thorns which are usually modified branches. Examples are Crataegus, Gleditschia, Prunus nigra, Sarcobatus, and Shepherdia argentea.

\section{PLANTS WITH STINGING HAIRS}

Only two genera are included in this group, namely Laportea and Urtica. $33532-6$ 


\section{AROMATIC PLANTS}

In this section are included plants that secrete resin or volatile oil in their tissues, but plants with sweet-scented flowers or fleshy fruits are not taken into consideration.

A. Resinferous plants are exemplified by most Canadian members of the group of Gymnosperms and by the fruiting catkins of Myrica Gale.

Gummy secretions are found in connection with the bracts of Grindelia and the bud-scales of Populus balsamifera.

B. Plants with aromatic roots and rhizomes are exemplified by Achlys, Aralia, Asarum canadense, Balsamorrhiza, Ligusticum scoticum, Panax and Osmorrhiza.

C. Plants with aromatic bark. Included here are Betula lutea, Liriodendron, Magnolia, and Ulmus fulva.

D. Aromatic leaves are found in Achlys, Acorus, Artemisia, Benzoin, Carya, Comptonia, Gaultheria procumbens, Hierochloë odorata, Hypericum, Juglans, many genera of the family Labiatae, Liriodendron, Magnolia, Mimulus , moschatus, Myrica, Ptelea, Rhus crenata, Sassafras, Tanacetum, and Xanthoxylum.

E. Aromatic fruits occur in many genera of Umbelliferae.

\section{PLANTS WITH MILKY JUICE}

Milky juice can be most readily detected in the younger parts of the plant where it flows out if the stem or leaf is broken. It is usually white in colour but is orange-red in Sanguinaria. It occurs also in Apocynum, Asclepias, Calystegia, Campanula, the family Cichoriaceae, Euphorbia, Lobelia, Morus, Papaver, and Rhus.

\section{PLANTS WITH WINGED FRUITS}

The wing on the fruit is provided for the purpose of dispersal by wind. Sometimes the wing is derived from a bract or other structure.

A. Herbaceous plants with winged fruits are exemplified by Angelica, Heracleum, Lomatium, Oxyria, Rumex and Statice.

B. Woody plants in this group include Acer, Alnus, Betula, Carpinus, Fraxinus, Liriodendron, Ostrya, Ptelea, Tilia, and Ulmus.

\section{PLANTS WITH HAIRY FRUITS}

In this case also the hairs serve for the dispersal of the fruits. Sometimes they are attached, not to the fruit but to some subsidiary structure. Examples are found in species of Anemone, Calamagrostis, various members of the families Carduaceae and Cichoriaceae, Clematis, Dryas, Eriophorum, Geum ciliatum, Phragmites, Typha, and Valeriana.

\section{PLANTS WITH HOOKED FRUITS}

Fruits of this type are adapted for distribution by animal agency. In this case also the hooks are of various types and may occur on the fruit or be derived from bracts or other structures.

A. The hooks or bristles occur on the fruit in Bidens, Caucalis microcarpa, Circaea, Ctenospermum, C'ynoglossum, Daucus pusillus, Desmodium, species of Galium, species of Geum, Glycyrrhiza, Lappula, Osmorrhiza, Ranunculus recurvatus, and Sanicula.

B. The hooks are on subsidiary structures in Agrimonia, Phryma, and Yanthium.

Note-A more detailed account of these special groups will be found in Bulletin No. $5 \mathrm{~S}$ New Series, "A Survey of Canadian Plants in Relation to their Environment", Ottawa, 1926, by the same author. 


\section{CHAPTER XXIV}

\section{USEFUL PLANTS}

Only the more important of the vild plants of Canada which are of service directly or indirectly to mankind are mentioned in this chapter. There are probably very few wild plants which do not fill some niche in the economy of nature either as food for wild animals or as food for insects which in turn may be eaten by birds or fishes. Further, a large number of wild plants were formerly, and are still to some extent, used by various Indian tribes for food, medicinal purposes, fishing nets, and domestic utensils.

\section{EDIBLE PLANTS}

The flowering shoot of the parasitic plant known as Poque (Boschniakia strobilacea) is edible but in the more important plants belonging to this group the edible part is either the underground organs or else the fruit; in the nutbearing species the edible part is the seed.

\section{A. Edible Roots, Tubers, or Bulbs}

Blue Camas (Camassia). One species occurs in southern Ontario and three in British Columbia.

Bitter Root (Lewisia rediviva). Occurs in the dry interior of British Columbia.

Ground-nut (Glycine Apios). An eastern species.

Chinook-licorice (Lupinus littoralis). Occurs on the sands of the Western coast.

Indian Bread-root (Psoralea esculenta). On the prairie.

Wild Caraway (Camım Gairdncii). Occurs in British Columbia.

Tobacco-root (Valeriana edulis). It occurs from Ontario to British Columbia.

Edible thistle (Cirsium, edule). Occurs in British Columbia.

\section{B. Edible îruits (Fleshy).}

Of the plants which bear fleshy, edible fruits the great majority are shrubs or small trees. Very few herbaceous plants have edible fruits.

(a) Herbs.

Northern Comandra (Comandra livilla). Occurs across Canada.

May-apple (Podophyllum peltatum) Eastern.

Strawberry (Fragdiria sp.) Wiclely distributed.

Smooth-fruited Prickly Pear (Opuntia humifusa). In southern Ontario.

Bramble (Rubus sp.). There are several herbaceous species with red fruits of which the Cloudberry ( $R$. Chamaemorus) and Arctic Bramble ( $R$. arcticus) extend across the northern parts of the continent.

(b) Dwarf Shrubs.

Crowberry (Empetrum nigrum). Occurs across Canada.

Creeping Snowberry (Chiogenes hispidula). Distributed across Canada.

Cranberry (Oxycoccus). Widely distributed.

Blackberries and Raspberries (Rubus sp.) may be grouped here. Most of the species occupy a sort of intermediate position between herbs and shrubs. 
They occur in both the East and West but are found principally in the more southern parts of the Dominion.

(c) Shrubs or Trees.

Hackberry (Celtis sp.). Occurs both in east and west.

Red Mulberry (Morus rubra). Occurs in Ontario.

North American Papaw (Asimina triloba). In southern Ontario.

Silver-berry (Elaeagnus commutata). Occurs across Canada.

Buffalo-berry (Shepherdia sp.). Widely distributed.

Gooseberry and Currant (Ribes $s p$.). Widely distributed.

Plum and Cherry (Prunus sp.). Widely distributed.

Juneberry (Amelanchier sp.). Widely distributed.

Hawthorn (Crataegus sp.). Mostly Eastern.

Chokeberry (Pyrus sp.). Eastern.

Grape (Vitis sp.). Eastern. fruits.

Blueberry (Vaccinium sp.) Widely distributed. Some species have red

Huckleberry (Gaylussacia sp.). Eastern.

Blue Fly-honeysuckle (Lonicera coemilea). Occurs across Canada.

Elder (Sambucus sp.). Widely distributed. tributed.

High-bush Cranberry, Nannyberry, etc., (Viburnum sp.). Widely dis-

\section{Nuts with Fidirle Seeds}

Butternut and Walnut (Juglans sp.). Eastern.

Hickory (Carya sp.). Eastern.

Hazelnut (Corylus sp.) Widely distributed.

American Chestnut (Castanea dentata). Occurs in southern Ontario.

\section{FORAGE PLANTS}

Only the more important pasture plants are mentioned here. There is stili much room for investigation on the feeding value and relative abundance of many species of wild plants.

\section{(1) Monocotyledons}

(a) Grass Family (Graminecie).

Colorado Bluestem (Agropyron Smithii). Prairie and western.

Big Bunch-grass (Agropyron spicatum). Western.

Slender Wheat-grass (Agropyron tenerum). Widely distributed.

Big Bluestem (Andropogon furcatus). Eastern and prairie.

Blue Grama-grass (Bouteloua gracilis). Prairie.

Short-awned Brome-grass (Bromiıs marginatus). Western.

Buffalo-grass (Buchloë dactyloides). Prairie.

Big Sand-grass (Calamovilfa longifolia). Widely distributed.

Tussock-grass (Deschampsia caespitosa). Widely distributed.

Spike-grass (Distichlis spicata). Widely distributed.

Wheat Lime-grass (Elymus triticoides). Prairie.

Sheep's Fescue (Festuca ovina). Western.

June-grass (Koeleria cristata). Widely distributed.

Smooth Spear-grass (Poa laevigata). Widely distributed.

Tall Meadow-grass (Panicularia nervata). Widely distributed.

Small Cord-grass (Spartina gracilis). Prairie and western.

Rough-leaved Dropseed (Sporobolus asperifolius). Prairie and western.

Feather Bunch-grass (Stipa viridula). Prairie and western. 
(b) Sedge Fanily (Cyperaceae).

Tall Swamp-sedge (Carex exsiciata). Western.

Elk-grass (Carex Geyeri). Western.

Sheep Sedge (Carex illota). Western.

(c) Rush Family (Juncaceae).

Rush (Juncus Parryi). Western.

Wood-rush (Luzula parviflora). Widely distributed.

(2) Dicotyledons

Fire-willow (Salix scouleriana). Prairie and western.

Fireweed (Epilobium angustifolizim). Widely distributed.

Tall Mountain-bilberry (Vaccinium membranceum). Western.

Blue Beardtongue (Pentastemon procerus). Western.

Black-berried Elder (Sambucus melanocarpa). Western.

Western Valerian (Valeriana sitchensis). Western.

Mountain-dandelion (Agoseris glauca). Prairie and western.

Woolly Weed (Hicracium cynoglossoides). Western.

Woolly Yarrow (Achillea lanulosa). Widely distributed.

Butterweed (Senecio triangularis). Prairie and western.

\section{FOODS OF WILD DUCKS AND OTHER GAME}

A very large number of plants furnish food for birds and mammals. Bears are very fond of sweet juicy fruits such as the various species of Blackberry (Rubus). The fleshy roots of the Western Yellow Waterlily (Nymphozanthus polysepalus) are a favourite food of deer. The berries of Crowberry (Empetrum nigrum) are eaten by wild geese. Numerous species of plants-especially those with underground tubers-furnish food for wild ducks. Some of the most important of these are as follows:

Wild Rice (Zizania aquatica). Eastern. The seeds are eaten.

Eel Grass or Wild Celery (Vallisneria spiralis). Eastern. Both the leaves and buds are eaten.

Fennel-leaved Pondweed (Potamogeton pectinatus). Widely distributed. The tubers are eaten.

Wapato or Muskrat Potato (Sagnttaria latifolia). Widely distributed. The tubers are eaten.

Chufa (Cyperus esculentus). Eastern. Tubers edible.

Water-shield (Brasenia Schreberi). Widely distributed. The seeds are eaten.

Eastern Yellow Waterlily (Nymphozanthus advena). Eastern. The seeds are eaten.

\section{MEDICINAL PLANTS}

The number of wild Canadian seed-bearing plants mentioned as official in the British Pharmacopoeia and the United States Pharmacopoeia is compara- tively small and comprises the species listed below.

\section{(1) Herbs}

American White Hellebore (Veratrum viride). Occurs across Canada.

Bloodroot (Sanguinaria canadensis). Eastern.

May-apple (Podophyllum peltatum). Eastern.

Seneca-snakeroot (Polygala Senerja). Eastern and prairie. $33532-7 \frac{1}{3}$ 
Black Snakeroot (Cimicifuga raiemosa). Occurs in Ontario.

Golden Seal (Hydrastis canadensis). Occurs in Ontario.

Indian Tobacco (Lobelia inflata). Eastern and prairie.

Tar-weed (Grindelia squarrosa). Prairie.

\section{(2) SHRUBS}

Juniper (Juniperus communis). Occurs across Canada.

Sassafras (Sassafras officinale). Occurs in southern Ontario.

Prickly Ash (Xanthoxylum americanum). Eastern.

Witch-hazel (Hamamelis virginiona). Eastern.

Burning-Bush (Euonymus atropurpureus). Occurs in Ontario.

Sacred Bark (Khamnus purshiana). Western.

Checkerberry (Gaultheria procumbens). Eastern.

Bearberry (Arctostaphylos Uva-Ursi). Occurs across Canada.

Nannyberry (Viburnum Lentago). Eastern.

\section{(3) TREFS}

Balsam-fir (Abies balsamea). Eastern and northern.

Sweet Birch (Betula lenta). Eastern.

Red Elm (Ulmus fulva). Eastern

Black Cherry (Prunus serotina). Eastern.

\section{PLANTS THAT FURNISH TIMBER}

The timbers of commerce serve a great variety of purposes, being used for building construction, furniture, vehicles, boats and shipbuilding, boxes and crates, tools and implements, paper-pulp, railway-ties and telegraph-poles, as well as being a most important fuel.

Timbers may be classified in various ways according to their properties. A few brief notes on these qualities may be of interest.

\section{(1) HARDNESS}

The hardest Canadian species of wood are Hickory, Dogwood, Sugar Maple, Sycamore, and Hornbeam.

Next in order of hardness are Ash, Oak, Elm, Beech, Cherry, Birch and Black Gum.

Among the soft woods are Chestnut, Tulip, Poplar, Douglas Fir, Fir, Yellow Pine, Larch, Basswood, Hemlock, Cottonwood, Spruce.

The softest woods are White Pine and Willow.

\section{(2) Creavibility}

The woods that are hardest to split comprise Black Gum, Elm, Sycamore, Dogwood, Beech, Maple, Birch, Hornbeam.

In a medium class come Oak, Ash, Larch, Cottonwood, Basswood, Tulip, Poplar, Hickory.

The woods most easily split are Chestnut, Pine, Spruce, Fir, Cedar.

\section{(3) Heating Power Per Cord}

The woods possessing greatest heating power are Hickory, Beech, Hornbeam, and heartwood of Pine.

Next to these are Oak, Ash, Birch, and Maple. 
Inferior in heating power are Spruce, Hir, Chestnut, Hemlock, and sapwood of Pine.

The timbers with lowest heating power are White Pine, Alder, Basswood, and Cottonwood.

\section{SAND-BINDING PLANTS}

In certain localities shifting sands are liable to cause trouble and the only permanent remedy is to induce the growth of certain species of plants, the rhizomes and roots of which bind the sand together. Only a comparatively few species of plants will grow in such a dry medium, the most important of these being the Marram-grass (Ammophila arenaria). Next in order may be mentioned Sea Lyme-grass (Elymus arenanius) Sea Lungwort (Mertensia maritima), Sea Purslane (Minuartia peploides) Sea Bindweed (Calystegia Soldanella), and Beach Pea (Lathyrus maritimus).

Other plants have been found acting as sand-binders at Point Pelee in Lake Erie. These are the trailing variety of Common Juniper (Juniperus communis), Big Sand-grass (Calamovilfa longifolia), Fragrant Sumac (Rhus crenata) and Bearberry (Arctostaphylos Ci'a-Ursi).

\section{PLANTS USED FOR TANNING}

A large number of plants contain tannin in their tissues but it is only certain species which contain it in sufficient quantity to be of commercial importance. It is most abundant, as a rule, in the liark of trees but may also occur in the wood or in the leaves. species.

1. Tannin is found in considerable quantities in the bark of the following

Hemlock (Tsuga canadensis). Eastern.

White Spruce (Picea canadensis). Eastern and Northern mainly.

Tamarack (Larix Laricina). Eastern and northern.

Balsam Fir (Abies balsamea). Enstern and northern.

White Oak (Quercus alba). Eastern.

Chestnut Oak (Quercus Prinus). Southern Ontario.

Red Oak (Quercus rubra). Eastern.

2. The wood of the Chestnut (Castanea dentata) furnishes tannin. This species occurs only in southern Ontario.

3. Among the various species of plants used for tanning purposes the Sumacs occupy an important position. The leaves and young stems of the following species are collected.

Dwarf Sumac (Rhus copallina). Ornire in southerr Ontario.

White or Smooth Sumac (Rhus glabra). Extends across Canada.

Staghorn Sumac (Rhus hirta). Eastern. 


\section{INDEX TO LATIN NAMES-FAMILIES, GENERA, AND SYNONYMS}

A.

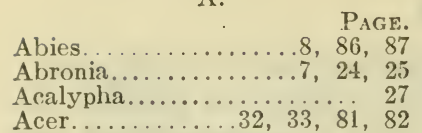

Acerates $=$ Gomphocarpus.

Achillea............77, 78, 85

Achlys........... . 38,82

Acnida.

Acomastylis $=$ Geum.

Aconitum............36, 37

Aconogonum $=$ Polygonum.

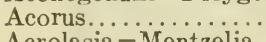

Acrolasia = Mentzelia.

Actinea.

Actinclla = Actinea

Adenocaulon. .

Adlumia.

Adopogon.

Adoxa

Agalinis $=$ Gerardia .

Agastache...

Agoseris.

Agrimonia.

Agropyron. .

Agrostis........

Aletris.

Alisma.

A.lionia.

Allium.

Allocarya

Allotropa.

Alnus.

Alopecurus.

$12,81,82$

(1)
Archangelica = Angelica, and Coclopleurum.

A

Arabidopsis = Arabis

Arabis

ARACEAE.

Aragallus = Oxytropis.

Aralia

ARALIACEAE

Arbutus.

Arceuthobium

Archemora=Oxypolis.

Arctagrostis......

$.36,37$ Arctostaphylos.......58, 86, 87

36, 37 Arctostaphylos.........58,
76, 78 Arctous=Arctostaphylos.

Arenaria = Minuartia.

75, 78 Arethusa...

40, 80 Argentina=Potentilla

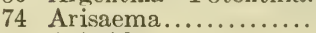

54, 56 Aristida.

Armeria = Statice.

66 Arnica................77, 78

74, 85 Aronia = Pyrus

$44,45,82$ Artemisia..

18, 84 Aruncus.

14, 16, 18 Asarum

Asarum.

$\ldots \ldots \ldots 75,78,82$

44,45

22,23

6,12

Cacalia = Mesadenı.

B

PAGE.

Brachyactis.........77, 78

Brachyelytrum........14, 16, 18

Brasenia.........37, 38, 81, 85

Brauneria............... 77,78

51,82 Braya................... 41

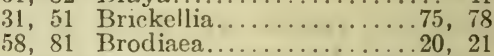

Bromus............ 14, 84

Buchloë.......14, 15, 18, 84

Buchnera............... 68

Rulbilis = Buchloë.

Bupleurum..........51, 53

CACTACEAE.......4, 30, 50

Cakıle................40,4!

Calamagrostis........16, 18, 82

Calamintha=Clinopodium.

Calamovilfa...14, 16, 18, 84, 87

Calandrinia............. 39

Calceolaria $=$ Hybanthus.

Calla.................... 81

Callitriche...........24, 25, 81

Calochortus.......... 20, 21

Calopogon................, 23

10, 81 Asimina.......................

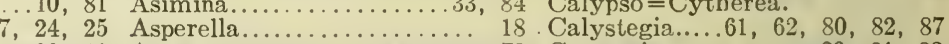

Alsine $=$ Stellaria, Spergularia

and Minuartia.

Alsinopsis $=$ Minuartia .

AMARANTACEAE.

Amarantus.

Amarella= Gentiana.

AMAR YLLIDACEAE.

Ambrosia.

AMBROSIACEAE

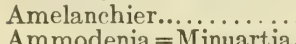

Ammodenia = Minuartia.

Ammophila.......14, 15, 18, 87

Amorpha................. 42,47

Amphicarpa.........46, 47, 80

Amsinckia...

Anaphalis.

Andromeda.

Andropogon

Androsace.

Anemone.

Anemonclla=Syndesmon.

Angelica.

Anogra = Oenothera.

Antennaria

Anthopogon=Gentiana.

Anticlea = Zygadenus.

Antiphylla.

Anychia....

Apargidium

Aphanes =Alchemilla.

Aphyllon=Thalesia.

Apinus $=$ Pinus.

Apios = Glycine.

Aplectrum

Aplopappus $=$ Haplopappus.

Apocynum........ 7, 55,

Aquilegia.

20. 21 Aster.

63 Astragalus.

57 Atclophragma = Astragalus.

14, 15, 18 Athysanus.

25,28

10,22

73

Balsamorrhiza......... $76,78,82$

Cassandra=Chamaedaphne.

Barbarea = Campe.

Castalia $=$ Nymphaea

Atragene $=$ Clematis

Atriplex....

Avena.

.40, 41 Capnoides = Corydalis.

78 Camassia............20, 21, 83

CAMPANÜ̈ӒEAE.....55, 71

Campe................, 41

CAPRIFOLIACEAE 54, 55, 70

24, 28 Cardamine............. 41

16,18 CARDUACEAE......73, 74,82 Carex..........12, 13, 81, 85 Carpinus.............9, 82 Carum..............53, 83 Carya..... $7,25,26,81,82,84$ B

Bartonia.................61, 80

Batidaea $=$ Rubus

$7 \dot{7}, 78$ Beckmannia...........

8 Benzoin

BERBERIDACEAE..6, 32, 38

37,82

53,82

75,78

Besseya= Synthyris.

Betula 9

$.52,53$

BETULACEAE....... 82,80

Bicuculla= Dicentra.

Bidens.

Bilderdykia = Polygonum

Bistorta = Polygonum .

49 Blephariglottis = Habenaria.

24, 25 Blepharipappus..............

74 Blephilia........................ 66

Blitum................. 28

Boehmeria.

Boisduvalia $=$ Oenothera

Bolelia

22, 23 BORAGINACEAE.......56, 62

Boschniakia...........67, 83

56,82 Bouteloua.

36,37 Boykinia = Therophon. 
Chamomilla $=$ Matricaria. Cheiranthus $=$ Erysimum. Cheirinia =Erysimum .

\section{Chelone.}

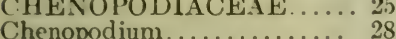

Chimaphila............... 57

Chiogenes..............59, 83

Chondrophylla = Gentians.

Chondrosea $=$ Saxifraga .

Chrysanthemum........77, 78

Chrysopsis............77, 78

Chrysospeenium......... 7, 48, 49

Chrysothamnus...........75, 78

CICHORIACEAE........73, 82

Cicuta ...............55, 81

Cimicifuga..........36, 37, 86

Cinna.............14, 16, 18

Circaea...............50, 82

Cirsium.........75, 78, 81, 83

CISTACEAE........... 31, 43

Cladium..............12, 13

Cladothamnus............... 58

Clarkia.................. 50

Claytonia.............. 39

Clemaıis..30, 32, 36, 37, 80, 82

Cleome................. 32,34

Clinopodium................65, 66

Clintonia................. 21

Cochlearia.

Coeloglossum = Habenaria.

Coelopleurum............... 53

Coleosanthus = Brickellia .

Collinsia 67,68

Collinsonia...............65, 66

Coslomia.................. 64

Comandra.............24, 26, 83

Comarum = Potentilla.

COMPOSITAE $\ldots \ldots \ldots \ldots . .54,73$
Comptonia........

Conioselinum...........52, 53

Conobea $\ldots \ldots \ldots \ldots \ldots \ldots \ldots \ldots$
Conopholis............... 68

CONVOL VULACEAE...55, 61

Coptidium $=$ Ranunculus.

Coptis................. 36, 37

Corallorrhiza........22, 23, 80

Corema...........6, 7, 33, 34

Coreopsis................76, 78

Corispermum............... 28

Cornus.......... 30, 32, 33, 34

Corydalis................ 40

Corylus..................29, 84

Coryphantha = Mammiliaria.

Cosmia = Calandrinia.

Cracca $=$ Tephrosia.

Crantzia = Lilaeopsis.

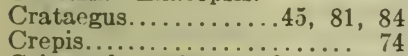

Criosanthes = Cypripedium.

Crocanthemum = Helianthemum.

Crocidium .............

CRUCIFERAE........... 32,40

Crunocallis=Claytonia.

Cryptantha.

Cryptotaenia............... 52,53

Ctenophyllum = Astragalus.

Ctenospermum..........63, 82

Cubelium $=$ Hybanthus.

CUCURBITACEAE.... .55, 71

Cuscuta........... $54,56,80$

Cyanococcus $=$ Vaccinium .

Cyclachaena.

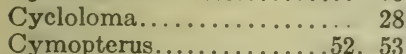

Cynoglossum.........6. 83,82
Cynoxylon $=$ Cornus.

Cynthia = Adopogon.

CYPERACEAE.

Cyperus............12, 13, 85

Cypripedium...............22, 23

Cytherea................ 23

\section{$\mathrm{D}$}

Datibarda.

Danthonia.

$\ldots \ldots \ldots .44,45$

Dasiphora = Potentilla.

Dasystephana $=$ Gentiana.

Dasystoma $=$ Gerard 1 .

Daucus..............

Delphinium...........36, 37

Dentaria.

Deringa $=$ Cryptotaenia .

Deschampsia.....14, 17, 18, 84

Desinodium..........46, 47, 82

Deycuxia $=$ Calamagrostis

Dianthera...........55, 56,81

Diapensia.................54, 56

Dicentra.................. 40

Diervilla...

Digitaria = Panicum.

Diholcos = Astragalus

Dioscorea........6. $9,10,80$

Diplopappus............. 77,78

Diplogon $=$ Chrysopsis

Direa.............. 7, 25, 26

Disporum............... 21

Distegia = Lonicera

Distichlis........14, 15, 18, 84

Dodecatheon................ 60

Doellingeria = Diplopappus.

Dondia $=$ Suacda.

Douglasia.

Drabe................... 60

Draba.................. 41, 42

Drosace $=$ Androsace

Drosera...........30, 34, 80

Dryas................44, 45, 82

Drymocallis $=$ Potentilla .

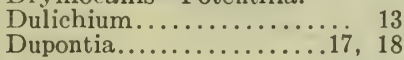

\section{$\mathrm{E}$}

Eatonia $=$ Sphenopholıs

Echinacea =Brauneria.

Echinochloa = Panicum.

Echinocystis

71,80

Echinodorus

10,81

Echinopanax......33, 34, 51, 81

Echinospermum =Lappula.

Elaeagnus..........25, 26, 84

Elatine........... $7,30,34,81$

Eleocharis = Heleocharis.

Elephantella = Pedicularis.

Ellisia................ 62

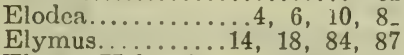

Elyna = Kobresia.

Empetrum..6, 7, 33, 34, 83, 85

Endolepis=Atriplex.

Eprgaea................. 58

Epilobium.............50, 85

Epipactis............... 23

Epiphegus............66, 67

Eragrostis.............14, 17, 18

Erechtites............... 75,78

ERICACEAE.......7, 54, 57

Erigenia.............. 53

Erigeron...................... 78

73 Eriocaulon.................. 81

Eriocoma=Oryzopsis.

Eriogonum.........25, 27, 28

Eriophorum........... $13,81,82$
Eriophyllum

Erxlebenia = Pyrola.

Eryngium

Erysimum.

Erythronium.

Eucephalus =Astcr.

Euonymus..

Eupatorium

PAGE.

76,78

51,53

41,42

20,21

Euphorbia.

$32,34,86$

75,78

EUPHORBIACEAE …27, 82

Euphrasia......67, 68, 69, 80

Eurotia................. 28

Euthamia=Solidago

Eutrema.............41, 42

F

FABACEAE.......... 31,46

FAGACEAE............25, 29

Fagus..............29, 81

Falcata = Amplicarpa.

Fatsia =Echinopanax .

Ferula = Leptotaenia (partly)

Festuca..........14, 18, 84

Fimbristylis...........12, 13

Fissipes =Cypripedium

Floerkea..........6, 31, 34

Fluminia.............. 17,18

Fragaria..............44, 45, 83

Franseria................. 73

Frasera................. 61

Fraxinus.......7, 54, 56, 81, 82

Fritillaria............20, 21

FUMARIACEAF.......... 41,40

G

Gaertneria $=$ Franseria.

Gaillardia.............76, 78

Galeorchis............ 23

Gaultheria............58, 82,86

Gaura.................... 50

Gaylussac1a...........50, 84

Gayophytum..............50, 51

Gentiana.............. 61

GENTIANACEAE......56, 61

Geoprumnon $=$ Astragalus .

Geranium...............31, 34

Gerardia.................... 68,69

Geum............44, 45, 82

Gilia..................... 64

Gillenia.................... 44,45

Glaux................ 7,60

Gleditschia............ 32, 34, 81

Glchnia.

Glyceria $=$ Panicularia .

Glycine.......46,47,80,83

Glycosma $=$ Washingtonia

Glycyrrhiza............47, 82

Gnaphalium.............. 75,79

Godetia $=$ Oenothera

Gomphocarpus.

Goodyers = Paremium

Gormania =Sedum

GRAMINEAE.

$.9,14,84$

Graphephorum = Fluminia and Trisetum.

Gratiola.

Greeneocharis=Piptocalyx

Grindelia........76, 79, 82, 86

Grossularia $=$ Ribes

Gu,ierrezia....

76,79

Gymnocladus.

$32,34,81$

$\mathrm{H}$

Habenaria.

23

Halenia.

61 
Haplopappus............77, 79

Harpaecarpus $=$ Madia.

Harrimanella = Cassiope

Hedeoma.............65, 66

Hedysarum...........46, 47

Helenium............76, 79

Heleocharis.............13, 81

Helianthella............77, 79

Helianthemum .

Helianthium $=$ Echinodorus

Helianthus............77, 79

Heliopsis................ 76, 79

Helıotropium............. 63

Hemicarpha..............12, 13

Hemieva $=$ Suksdorfia.......

Hemitomes.............. 57

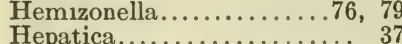

Heracleum..........5 5 53, 82

Hesperopeuce $=$ Tsuga .

Hesperoscordum =Brodiaea .

Heteranthera............10,

Heterisia = Saxifraga.

Heterocodon $=$ Campanula .

Heuchera...

Hibiscus.

Hicoria = Carya.

Hieracium

Hierochloë

Hippuris

Hoita $=$ Psoralea

Holodiscus.

Homalobus = Astragalus

Homalocenchrus = Leersia.

Honkenya $=$ Minuartia.

Hookera = Brodiaea.

Hordeum.

Hosackia.

Houstonia

Hudsonia...

Hutchinsia.

Hybanthus.

Hydastylus = Sisyrinchium.

Hydatica $=$ Saxifraga

Hydrastis..........36, 37, 86

Hydrocotyle.

HYDROPHYLLACEAE 56, 62

Hydrophvllum.........., 62

Hymenopappus............75, 79

Hymenoxys $=$ Actinea .

Hypericum.

Hypopitys.

Hypoxis.

Hystrix = Asperella

\section{I}

Ibidium $=$ Spiranthes

Ilex.

Ilicioides $=$ Nemopanthus

Ilysanthes.....

Impatiens.

Ionactis $=$ Diplopappus.

Ipomoea.

IPI

IRIDACEAE............................... 22

Isanthus.

Isnardia.

Isopyrum

Isotria.

$30,34,82$

Iva.

\section{$\mathrm{J}$}

Jacksonia $=$ Cleome

Jaumea.............76, 79

Jeffersonia.

Juglans.... $7,25,26,81,82,84$
JUNCACEAE.

Juncoides = Luzula.

Juncus.............
Juniperus....... $10,81,85,81,86,87$

\section{$\mathrm{K}$}

Kalmia

Kentrophyta = Astragalus

Kneiffia = Oenothera.

Kobresia....

Kocleria.

Koellia = Pycnanthemum

Koenigia................

Krigia...

Kruhsea = Streptopus

Krynitzkia=Cryptantha.

Kuhnistera $=$ Petalostemon

\section{LABIATAE.....54,55, 65, 82}

Laciniaria = Liatris.

Lactuca. .

74

Lagotis.............. $55,68,69$

Laportea................. 27, 81

Lappula..............663, 82

9 Larix...............8,81, 87

Lathyrus........46, 47, 80, 87

LAURACEAE .......6, 33, 38

Lavauxia = Oenothera.

Layia................78, 79

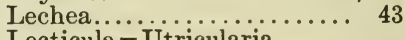

Lecticula = Utricularia

Ledum .............. 58, 59

Lemna.........4, 6, $4,10,81$

LEMNACEAE......... 4

LENTIBULARIACEAE.55, 67

Lepachys $=$ Ratibida .

Lepargyraea = Shepherdia.

Lepidium.

Lepigonum = Spergularia.

Leptamnium $=$ Epiphegus.

Leptandra $=$ Veronica.

Leptarrhena = Saxifraga.

Leptasea $=$ Saxifraga

Leptaxis $=$ Tolmiea.

Leptilon...

Leptodactylon = Gilia.

Leptotaenia...

Lespedeza.

Lesequerella....

Leucanthemum $=$

Chrysanthemum.

Leucocoma=Eriophorum.

Leucophysalis = Physalis.

Lewisia............... 39, 83

Liatris................. 75,79

Ligusticum..........52, 53, 82

Lilaea............. 10,81

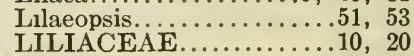

Lilium............6, 20, 21

Limnanthemum $=$ Nymphoides.

Limnanthes............. 34

Limnia = Claytonia

Limnobium............10, 81

Limnobotrya = Ribes.

Limnorchis = Habenaria.

Limonium............7, 55, 56

Limosella............. $68,69,81$

Linanthus = Gilia.

Linaria

Lindera = Benzoin.

Linnaea.

Linoides $=$ Millegrana.

Linum.................31, 34

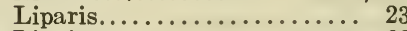

Lippiadendron............ $38,81,86$
L PAGE.

Listera................ 23

Lithophragma............... 49

Lithospermum........... 63

Littorella......... $75,56,81$

Lloydia...............20, 21

Lobelia.........71, 81, 82, 86

LOBELIACEAE........55, 71

Loiseleuria............58, 59

Lomatium............52, 53, 82

Lomatogonium = Pleurogyna.

Lonicera...........70, 80, 84

Lophanthus=Agastache.

Lophiola.................. 22

Lophotocarpus............... 81

Ludwigia...........50,51, 81

Luetkea...............44, 45

Luina.................75, 79

Lupinus.........46,47,83

Luzula...............10, 85

Lychnis..................

Lycopus...............65, 66

Lygodesmia...............74

Lysias= Habenaria.

Lysichiton............. 12

Lysiella = Habenaria

Lysimachia...........60, 81

Lythrum................ 31,34

M

Machaeranthera........78, 79

Macounastrum $=$ Koenigia .

Macrocalyx $=$ Ellisia

Madia...............76, 79

Magnolia................... 38,82

MAGNOLIACEAE. . 6, 32, 38

Mahonia.........32, 34, 38, 81

Maianthemum..........20, 21

Mairania =Arctostaphylos.

Malus $=$ Pyrus

MALVACEAE.......7, 30, 43

Malvastrum............... 43

Mammillaria..............50, 81

Mariscus $=$ Cladium

Matricaria.............77, 79

Medeola.............6, 20, 21

Megalodonta..........77, 79, 81 Megarrhiza = Echinocystis.

Meibomia $=$ Desmodium .

Melampyrum..........68, 69

Melica............14, 17, 18

Menispermum............. 34,80

Mentha................... 66

Mentzelia..............31, 34

Menyanthes..............61, 81

Menziesia.............58, 59

Merathrepta $=$ Danthonia.

Meriolix=Oenothera.

Mertensia..............63, 87

Mesadenia.................. 75,79

Micrampelis $=$ Echinocystis.

Micranthes=Saxifraga.

Micromeria.............65, 66

Microseris..............73, 74

Microsteris.............. 64

Microstylis................. 23

Mikania............75, 79, 80

Milium................. 16, 18

Mimulus...........68, 69,82

Minuartia..........39, 40, 87

Mitchella................ 70,71

Mitella...............48, 49

Mitellastra $=$ Mitella.

70 Moehringia $=$ Minuartia .

Moldavica.............6. 65,66

Monarda................65, 66

Moneses................. 57

Monolepis................. 28

Monotropa............... 57 
MONOTROPACEAE 54 PAGE.

Montia..... 39 Montiastrum $=$ Claytonia.

Morus..........25, 26, \&2, \$4

Muhlenbergia............ 16

Mulgedium = Lactuca. .

Munroa................14, 15, 18

Muscaria=Saxifraga.

Musenium = Musineon.

Musineon.............52, 53

Myosotis................. 63,64

Myosurus.............36, 37

Myrica............25, 26, 82

Myriophyllum...4, $7,24,26,81$

Myzorrhiza=Orobanche.

\section{$\mathrm{N}$}

Nabalus $=$ Prenanthes.

Naiocrene=Clay tonia.

Najas..........4, 6, 9, 10,81

Nardosmia = Petasites

Nasturtium........41, 42, 81

Naumburgia = Lysimachia.

Navarretia $=$ Gilia .

Negundo $=$ Acer.

Neillia = Physocarpus.

Nelumbium $=$ Nelumbo

Nelumbo............37, 38, 81

Nemesia = Smilax.

Nemopanthus...........33, 34

Nemophila............... 62

Neobeckia................4i, 42

Nephrophyllidium $=$ Menyanthes

Nesaea..................... 34

Nesodraba = Draba

Newberya $=$ Hemitomes.

Nicotiana.

Nuphar $=$ Nymphozanthus.

Nuttallia = Mentzelia and Osmaronia.

Nyctelea =Ellisia .

Nymphaea..........37, 38, 81

NYMPHAEACEAE..6, 31, 37

Nymphoides...........61, 81

Nymphozanthus... $37,38,81,85$

Nyssa............33, 34, 81

$$
\mathrm{O}
$$

Oakesia $=$ Uvularia

Ochrocodon = Fritillaria .

Ocrearia $=$ Saxifraga .

Odostemon= Mahonia .

Oenanthe.

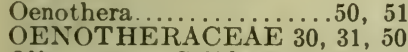

Oligoneuron=Solidago.

Olsynium $=$ Sisyrinchium .

Onosmodium...........63, 64

Opulaster $=$ Physocarpus.

Opuntia.............50, 81, 83

ORCHIDAC̈.̈. E........10, 22

Orchis..................... 23

Oreocarya..................... 64

Orobanche.................. 67

OROBA NCHACEAE $54,66,80$

Orophaca = Astragalus.

Orthocarpus............68, 69

Oryzopsis.................. 18

Osmaronia.............. 45

Osmorrhiza.........52, 53, 82

Ostrya..............29, 81, 82

Oxalis................. 31,34

Oxybaphus $=$ Allionia.

Oxycoccus.............59, 83

Oxygraphis $=$ Ranunculus.

Oxypolis..............52, 53

Oxyria...........27, 28, 82

Oxytropis.

Ozomelis=Mitella.
Pachylophus=Oenothera.

Pacliystima........... 32, 34

Padus $=$ Prunus.

Panax.

Panicularia...

$\ldots \ldots, 17,18,84$

Panicum.

$\begin{array}{ll}14,17, & 19 \\ \ldots .40,82\end{array}$

PAPAVERACEAE.......31, 40

Parietaria................. 27

Parnassia................ 48, 49

Paronychia..............24, 26

Parrya................ 41, 42

Parthenocissus.....7, 32, 34, 80

Pectiantia = Mitella

Pectocarpus $=$ Ctenospermum.

Pedicularis.

Pediomelum = Psoralea.

$68,69,80$

Pentastemon..........67, 69, 85

Penthorum............ $7,31,34$

Peramium.............. 23

Peritoma $=$ Cleome.

Persicaria $=$ Polygonum.

Perularia $=$ Habenaria.

Petalostemon.

46,47

Petasites. .

77,79

Peucedanum =Lomatium (partly)

Phaca $=$ Astragalus.

Phacelia...............

Phalaris............

Phaseolus.

62

Phellopterus=Glehnia (partly)

Philadelphus.........32, 48, 49 Philotria=Elodea

Phippsia.

$.15,19$

Phleum.

15,19

Phlox.

Phragmites.......14, 17, 19, 82

Phryma............55, 56, 82

Phyla=Lippia.

Phyllodoce...........58, 59

Phymosia = Sphaeralcea

Physalis................ 64

Physaria................. 4 i, 42

Physocarpus................44, 45

Physostegia = Dracocephalum

Phytolacca.......... 7, 24, 26

Picea.................... 8, 87

Pilea................... 27

PINACEAE........... 8

Pinguicula.............67, 80

Pinus................. 8

Piperia = Habenaria.

Piptocalyx............63, 64

Plagiobothrys...........63, 64

Plantago............ $7,55,56$

Platanus...............25, 26, 81

Platyspermum..........41, 42

Plastystigma........... 30,40

Plectritis $=$ Valerianella .

Pleiacanthus=Lygodesmia

Pleurogyna............. 61

Pneumaria $=$ Mertensia

Poa..........14, 17, 19, 84

Podophyllum......6, $38,83,85$

Podostemon....4, 7, 24, 26, 81

Pogonia..............22, 23

Polanisia............... 31,34

POLEMONIACEAE.54, 56, 64

Polemonium............. 64

Polycodium $=$ Vaccinium .

64

Polygala...........31, 35, 85

POLYGONACEAE...7, 24, 27

Polygonatum.............
Polygonella = Polygonum.

Page.

Polygonum.... . $, 27,28,80,81$ Polymnia..............76, 79

Pontederia...............10, 81

P’opulus...........29, 81, 82

Porteranthus $=$ Gillenia .

PORTULACACEAE.30, 31, 39

Potamogeton.4, 6, 9, 11, 81, 85

Potentilla..........44, 45, 81

Poteridium $=$ Sanguisorba .

Prenanthes.

Primula................ 60

PRIMULACEAE........55, 59

Prosartes $=$ Disporum .

Proserpinaca.......7, 24, 26, 81

Prunus.........45, 81, 84, 86

Psedera = Parthenocissus

Pseudotsuga............., 8

Psoralea.............46,47, 83

Psoralidium $=$ Psoralea .

Ptelea...............48, 82

Pterospora.............. 57

Ptilocalais $=$ Ptilophora

Ptilophora...............

Puccinellia...........14, 17, 19

Pulsatilla................. 37

Purshia..............44, 45

Pycnanthemum............65, 66

Pyrola.........54, 56, 57, 80

PYROLACEAE........7, .57

Pyrrocoma = Haplopappus.

Pyrus...............45, 84

Quamasia $=$ Camassia.

Quercus...........29, 81, 87

\section{$\mathrm{R}$}

Radicula $=$ Nasturtium

Radiola = Millegrana.

RANUNCULACEAE

6, 7, 31, 36

Ranunculus.........37, 81,82

Ratibida.................. 77,79

Razoumofskya = Arceuthobium.

Rhamnus.........7, $33,35,86$

Rhexia.................30, 35

Rhinanthus................. 68

Rhodiola $=$ Sedum

Rhododendron...........58, 59

Rhodora $=$ Rhododendron

Rhus........32, 35, 80, 82, 87

Rhynchospora...........13, 81

Ribes........33, 48, 49, 81, 84

Robertiella = Geranium

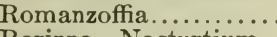

Rosa.............44, 45, 81

ROSACEAE.....30,32, 33, 43

Rubacer $=$ Rubus.

RUBIACEAE.........55, 70

Rubus....44, 45, 80,81, 83, 85

Rudbeckia............76, 79

Rulac $=$ Acer .

Rumex.........27, 28, 81, 82

Ruppia...............4, 9, 11

RUTACEAE..........32, 48

\section{$\mathrm{S}$}

Sabbatia

Sabina $=$ Juniperus.

Sagina..

Sagittaria

39,40

. $\ldots 10,11,81,85$

Salicornia..............25, 29 
Salix........... $7,29,81,85$ Ptenanthella=Stenanthium.

Salsola..............28, 81 Stenanthium..........

Sambucus...........70, 84, 85 Stenophyllus = Fimbristylis.

Samolus............59, 60 Stenotus= Haplopappus.

20,21

Triplasis...........14, 17, 19

Tripterocalyx $=\mathrm{A}$ bronia .

Trisetum...........16, 17, 19

Triteleia $=$ Brodiaea.

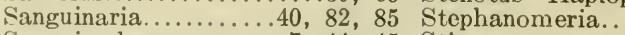

Sanguisorba.........7, 44, 45 Stipa.............. 19,84

Sanicula.........51, 52, 53, 82 Stomoisia = Utricularia.

Sarcobatus................ 81

Streptopus.

Strobus = Pinus.

Sarracenia...........30, 35, 80 Strophostyles........46, 47, 80

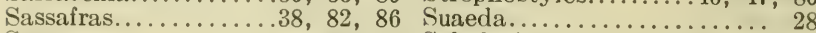

Saururus............24, 26, 81 Subularia............... 42,81

Saussurea..............75, 79 Suksdorfia..............48, 49

Savastana $=$ Hierochloë

Saxifraga

Svida = Cornus

SAXIFRÄGÄEÄ......... 4 , 49 Symplocarpus............... 70

Schedonnardus.........15, 19 Syndesmon.............. 37

Scheuchzeria............. 11 Syntherisma=Panicum.

Schizachyrium $=$ Andropogon .

Schoenocrambe $=$ Sisymbrium .

Scirpus..............13,81

Scleria.................... 12

Scolochloa $=$ Fluminia.

Scorzonella $=$ Microseris and Apargidium.

Scrophularia.

$\mathrm{T}$

Taenidia..............52, 53

Talinum.................... 39

Tanacetum...........76, 79, 82

SCROPHLT A RIACEAT 55,67

Scutellaria.............65, 66

Sedum...............31, 35

Selinum = Conioselinum (partly)

Senecio............. $77,79,85$

Sericocarpus...........78, 79

Sericotheca $=$ Holodiscus.

Shepherdia.......25, 26, 81, 84

Sibbaldia $=$ Potentilla.

Sibbaldiopsis= Potentilla.

Sicyos.

Taraxacum ..........

Taxus............

Tecoma................ 8

Telesonix = Saxifraga.

Tellima................ 49

Tephrosia..................... 47

Tetradymia.............. 75,79

Trollius...............36, 37

Troximon =Agoseris .

Tsuga................ 8, 87

Turritis $=$ Arabis

Typha.........9, 11, 81, 82

$\mathrm{U}$

Ulmus......25, 26, 81, 82, 86

UMBELLIFERAE...31, 51, 82

Unamia $=$ Aster..

Unifolium = Maian themum .

Urtica................27, 81

URTICACEAE............24, 27

Urticastrum $=$ Laportea.

Utricularia.........67, 80,81

Uva-ursi = Arctostaphylos.

Uvularia..............21, 22

\section{V}

VACCINIACEAE......54, 59

Vaccinium...........59, 84, 85 Vagnera = Smilacina

Valeriana........72, 82, 83, 85

VALERIANÄ̈EAE.....55, 72

Valerianella.............. 72

Vallisneria........10, 11, 81, 85

Veratrum..............21, 22,85

Verbena...................6 66

VERBENACEAE........55, 66

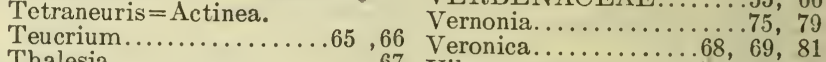

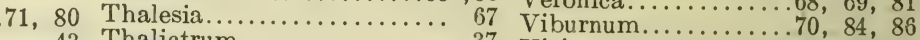

Sidalcea................. 43

Sideranthus $=$ Haplopappus.

Sieversia $=$ Geum .

Silene. .

Thalictrum............. 37

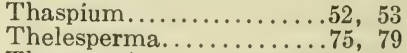

39, 40 Thermopsis.............46, 47

Sisymbrium.............41, 42 Therorhodion $=$ Rhododendron.

Sisyrinchium...................

Sium.............52, 53, 81

Smelowskia.............41, 42

Smilacina............... 21

Smilax........ 6, 20, 21, 80, 81

SOLANACEAE.......56, 64

Solanum................ 64

Solea $=$ Hybanthus.

Solidago.

Sophia $=$ Sisymbrium

Sorbus.

$.77,79$

Sorghastrum........

Sparganium............ 11,81

Spartina.........14, 15, 19, 84

Spathyema $=$ Symplocarpus.

Spatularia = Saxifraga

Specularia.

Spergularia.

..39, 40

Sphaerostigma = Oenothera

Sphenopholis...........17, 19

Spiraea.................4, 45

Spiranthes.

Spirodela = Lemna

Sporobolus........14, 16, 19, 84

Stachys....

Thlaspi...............41, 42

Thuja.................. 8

Thysanocarpus.............40, 42

Tiarella................. 49

Tigridia $=$ Sisyrinchium

Tilia............32, 35, 81, 82

Tillaea................30, 35

Tillaeastrum $=$ Tillaea.

Vicia............46, 47, 80

Viola..................... 48

VIOLAC̈EAE............... 48

Viscaria $=$ Lychnis

Vitis......... 33, 35, 80, 84

Vitis-Idaea $=$ Vaccinium

\section{W}

Wahlbergella = Lychnis

Waldsteinia.............44, 45

Washingtonia $=$ Osmorrhiza.

Wolffia.........4, 6, 9, 11, 81

Wyethia................ 76,79

Tissa = Spergularia.

Tithymalopsis = Euphorbia

Tithymalus $=$ Euphorbia .

Tium $=$ Astragalus.

Tofieldia.

Tolmiea.....

Tonestus $=$ Haplopappus.

Torresia $=$ Hierochloë.

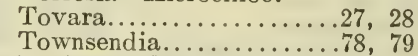

Toxicoscordion $=Z$ ygadenus .

Tracaulon= Polygonum .

Trautvetteria

Triadenum $=$ Hypericum .

Triantha=Tofieldia

Tricratus $=$ A bronia .

Trientalis.

$\mathrm{X}$

Xanthium.............73, 82

Xanthoxalis $=$ Oxalis.

Xanthoxylum.....48, 81, 82, 86

Xerophyllum..........21, 22

Xylophacos $=$ Astragalus.

$\mathrm{X}$ ylosteon $=$ Lonicera

Xyris..............10, 11, 81

Youngia $=$ Crepis. 37

Trifolium..................... 47

Staphylea.............32, 35

Statice........... $7,54,56,82$

Steironema $=$ Iysimachia.

Stellaria...

39,40
Triglochin................. 11

Trillium.......6, $10,20,21,22$

Triosteum............... 70

\section{Z}

Zannichellia.....4, 6, 9, 11, 81

Zanthoxylum = Xanthoxylum.

Zizania.......14, 16, 19, 81, 85

Zizia................... 52,53

Zostera...........4, 9, 11, 81

Zosterella = Heteranthera.

Zygadenus.............20, 22 
PAGE

Adam and Eve..

Adder's mouth.

Adder's tongue

Adder's tongue, Yellow........

Agrimony................. 4

Ague-tree.

Alder.

$\ldots \ldots \ldots \ldots \ldots, 89,87$

Alexanders, Heart-leaved.... 5

Alkali-grass. .............. 18

Alum-root............... 49

Anemone................ 37

Angelica.

Angelica, Purple-stemmed...

Antelope-brush.............

Arbutus, Trailing............ 58

Arnica.

Arnica, Rayless........... 78

Arrow-arum............... 12

Arrow-grass............... 11

Arrow-grass, Creeping....... 11

Arrow-grass, Marsh............

Arrow-grass, Sea............

Arrow-head................

Arrow-head, Sea............. 10

Arrow-wood............... 70

Arum, Water................. 12

Ash..................56, 86

Ash, Black............... 56

Ash, Blue............... 56

Ash, Prickly..........48, 86

Ash, Red...

Ash, White

Aspen

Asphodel, False...............

Aster.................78,

Aster, Biennial................. 7

Aster, Double-crowned.......

Aster, Golden................

Aster, Rayless.

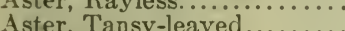

Aster, White-topped..........

Avens.

Avens, Mountain............ 45

Awlwort, Water.

\section{B}

Baby's Breath

Baeria, Sea $. \cdots . . . . . . . .6$

Ball-cactus............... 50

Ball-cactus, Yellow.......... 50

Balm, ............... 60

Balsam-apple

Balsam-apple, Wild.......... 71

Balsam-fir................ 86

Balsam-root............. 78

Balsam-root, Arrow-leaved....78

Bamboo-sedge.............. 13

Baneberry...................... 37

Baneberry, White...........

Barley.................. 18

Bartonia.

Bartonia, Purple.

Bartonia, Yellow.................

Bartsia, Alpine............... 68

Basil....................... 66

Basil, wild.................... 66

Basswood................. 86,87

Bayberry.................. 26

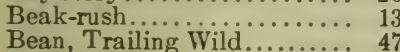

Bean, Wild................ 47
Bearberry, Alpine......... 5

Bear-grass......................... 22

Beard-grass.............. 18

Beard-tongue, Blue ........... 85

Beard-tongue, Hairy............. 6

Bedstraw.............. 7

Bedstraw, Northern..........

Bedstraw, Sweet-scented.... 7

Beech..................29, 80

Beech, Blue............. 29

Beech-drops.............. 67

Beggar-ticks.

Bellflower.

Bellflower, Tall

Bellflower, White

Bellwort.

Bent-grass. . A.................

Bergamot.

Betony, Wood..................... 69

Bilberry.

Bilberry, Red

Bilberry, Tall Mountain....

Bindweed

Bindweed, Dwarf

Bindweed, Great.

Bindweed, Sea..........62, 8

Birch..................29, 86

Birch, Sweet............ 86

Biscuit-root................ 53

Bitter-root............... 39

Bittersweet, Climbing....... 34

Blackberry $\ldots \ldots \ldots \ldots \ldots . . . .83,85$

Black-eyed Susan........... 79

Bladder-fruit, Woolly....... 79

Bladder-nut.............. 35

Bladder-pod.............. 42

Bladder-pod, Double........ 42

Bladderwort............ 67

Bladderwort, One-flowered.. 67

Blanket-flower............. 78

Bleeding-heart.............. 40

Bleeding-heart, One-flowered 40

Bloodroot..............40,85

Blueberry.................

Blue-hearts.................... 68

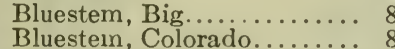

Bluestem, Colorado........ 8

Bluets.................... 71

Bluets, Fringed.................

Bog-bean................ 6

Bolelia................ 7

Bottle-sedge.................... 13

Bowman's root................ 45

Bramble..............45, 83

Bramble, Ärtic............. 83

Bread-root................... 47

Bread-root, Indian........... 83

Bread-root, Sainfoin.......... 47

Brides, Morning............. 78

Brome-grass.............. 18

Brome-grass, Short-awned... 84

Bronze-bells.............. 21

Brookweed.

Broom, Sweet......................

Broom, Northern Sweet..... 47

Broomrape...............6. 67

Broomrape, Woolly-stamened

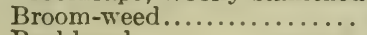

Buckbrush.
B

PAGE

Buckthorn............. 35

Buckthorn, Alder-leaved..... 35

Buffalo-berry ............26, 8

Buffalo-berry, Smooth....... 26

Buffalo-berry, Thorny....... 26

Buffalo-grass............ 18 , 4

Buffalo-grass, False.......... 18

Bugbane.................. 37

Bugbane, False.............. 37

Bugle-weed............... 66

Bug-seed.............. 29

Bulrush....................

Bunchberry.............. 34

Bunch-grass, Big........... 84

Bunch-grass, Feather....... 81

Bur-cucumber, One-seeded... 71

Bur-marigold............. 78

Bur-marigold, Narrow-leaved 79

Bur-marigold, Nodding...... 78

Burnet................. 45

Burnet, Great.............

Bur-ragweed............... 73

Bur-ragweed, Annual....... 73

9 Bur-reed................. 11

Bush, Benjamin................... 38

Bush, Burning..........34, 86

Bush-clover................. 47

Bush-cranberry, High.....70, 84

Bush, Hobble............ 70

Bush-honeysuckle............. 70

Buttercup................. 37

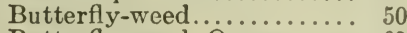

Butterfly-weed, Orange......... 62

Butterfly-weed, Pink....... 50

Butterfly-weed, Scarlet....... 50

Butternut.............26, 84

Butterweed................ 85

Butterwort................... 67

Button-bush................ 71

Button-snakeroot............. 79

Cactus, Purple............ 50

Calamint, Smooth............... 66

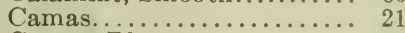

Camas, Blue................. 83

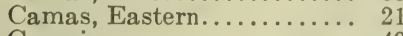

Campion................... 40

Canary-grass, Reed.......... 19

Cancer-root................... 67

Cancer-root, One-flowered... 67

Caraway.................. 53

Caraway, wild................ 83

Cardinal-flower............ 71

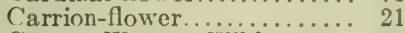

Carrot, Western Wild........ 53

Catchfly.............. 40

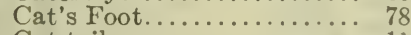

Cat-tail.................. 11

Cedar.................... 86

Cedar, Western............. 8

Cedar, White............. 8 . 8

Chaffweed.................. 60

Chamomile.................. 79

Checkerberry.............. 8,86

Cherry............45, 84, 80

Cherry, Black.............. 86

Chervil.................. 53

Chestnut.............29, 86,87

Chestnut, Ämerican........ 84

Chickweed ............ 40

Chickweed, Forked............ 25

44 Chickweed, Mouse-ear....... 40 
C

Chinonk-licorice

Chokeberry.

Chokeberry, Black

Chrysanthemum

Chufa.

Cicely, Sweet

Cinquefoil.

Cinquefoil, Five-flowered.

Clearweed

Cleft-lip.

Clematis, Woolly.

Clintonia, Yellow

Clotbur.

Cloudberry.

Clover.

Clover, Buffalo

Clover, Owl's.

Clover, Prairie Owl's

Club-fruit.

Club-rush.

Cocklebur

Coffee-tree, Kentucky

Cohosh, Blue.

Colic-root.

Collomia

Coltsfoot, Sweet.

Coltsfoot, Arrow-leaved

Sweet.

Columbine.

Columbine, Wild

Columbo, American

Comandra, Northern

Compass-plant.

Cone-flower

Cone-flower, Gray-headed.

Cone-flower, Prairie.

Cone-flower, Purple.

Cone-flower, Tall. .

Cone-plant.

Coolwort.

Copper-bush

Coral-root.

Cord-grass

Cord-grass, Small

Cornel.

Corn-salad.

Corn-salad, Spurless.

Corydalis.

Corydalis, Pink.

Cotton-grass

Cottonwood

Cowbane.

Cowberry.

Cow-parsnip

Cowslip, American

Cowslip, Virginian.

Cow-wheat.

Crab-apple.

Cranberry.

Cranesbill.

Cream-cups.

Creeper, Virginian

Cress, Alpine.

Cress, Bitter

Cress, Naked

Crosswort.

Crowberry

Crowberry, Broom

Crowberry, Northern.

Crowfoot

Cucumber-root, Indian.

Cucumber-tree

Cudweed.

Culver's root.

Cup, Broad.

Cup, Indian

Cup-plant.

Currant

Currant, Golden...
PAGE

C

PAGE

PAGE

83 Cut-grass.

45,84 Cypress-sedge..
Cypress, Yellow.

\section{D}

Dandelion.

Dandelion, Dwarf

Dandelion, Mountai

Death-camas.

Deerberry. .

Deer-cabbage

Desert-pink.

Devil's Club. .

Devil's Tongue.

Dewdrop.

Dock.

Dodder.

Dogbane.

Dogwood, Äiternate-leaved..

Dogwood, Flowering........ 34

Dogwood, Western.......... 34

Dragon-head.

Dragon-head, False

Dragon-root.

Dragon's mouth.

Drop-cup.

Dropseed.

Dropseed, Rough-leaved..... 84

Duckweed............... 10

Duckweed, Greater........... 10

Duckweed, Rootless.

Dutchman's Breeches.

Dwarf-parsley................

\section{$\mathrm{E}$}

Eel-grass.

Eel-grass, Sea.................. 85

Elder...............70, 84

Elder, Black-berried.........70, 85

Elder, Poison.

Elder, Purple-berried..........

Elder, Red-berried.

Elder, Wax-berried

Elephant-flower.

Elk-grass.

Elm....................... 86

Eryngo.

Everlasting..............

Everlasting, Clammy.................... 79

Eyebright.............. 69

Fairies, Pink $F$

Fairy-bells.

Fairy-bells, Downy

Fan-weed.

Feather-grass.

Felwort, Mars

Fescue-grass. .

Fiddle-neck.

Figwort.

Fir.

Fir, Balsam

Fir, Douglas.

Fireweed.

Fireweed, White

Fire-willow.

Flag

49 Flax, Yellow
Ditch-grass.

Ditch-stonecrop

Flag, Sweet.

18 Fleabane.

F

78

Ty-honeysuckle, Blue.....70, 84

Foamflower............. 49

Fog-fruit.................. 66

Fool's Huckleberry.......... 59

74 Forget-me-not............ 64

74 Forget-me-not, Smaller....... 64

85 Forget-me-not, White....... 64

74 Foxtail................. 18

22 Fringe-cup................ 49, 78

Frog's Bit............... 10

Frost-weed.............. 43

4 Fumitory, Climbing........ 40

G

Garlic................ 21

Gentian.............................. 61

Gentian, Spurred.......... 61

Gerardia............... 69

Germander....................... 66

Ghost-pipes............. 67

Giant-hyssop...................... 66

Giant-hyssop, Fragrant..... 66

Gilia................... 64

Gilia, Dense-flowered.......... 64

Gilia, Dwarf............... 64

Ginger, Eastern Wild......... 25

Ginger, Western Wild....... 25

Ginger, Wild.............. 25

Ginseng................ 51

Ginseng, American......... 51

Ginseng, Dwarf............. 51

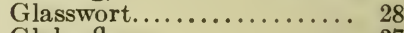

Globe-flower............ 37

Globe-mallow............ 43

Goat's Beard................. 45

Goat's Beard, Virginian..... 74

Goat's Chicory............. 74

Goat's Rue............... 47

Golden-rod................ 79

Golden-rod, White.......... 79

Gold-fields............... 78

Gold-thread.................... 37

Gold-thread, Common...... 37

Gold-thread, Western........ 37

Gooseberry...............49, 84

70 Goosefoot.................. 28

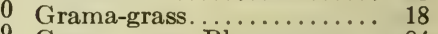

Grama-grass, Blue......... 84

Grape...................... 84

Grass, Blue-eyed.............. 22

Grass, Bottle-brush......... 18

Grass, Dwarf................. 19

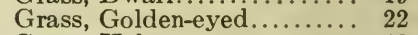

Grass, Holy............. 18

Grass, Indian............. 19

Grass of Parnassus......... 49

Grass, Orange............. 34

50 Grass, Salt-meadow......... 19

21 Grass, White............ 18

21 Grass, Yellow-eyed............. 11

42 Grass-pink................. 23

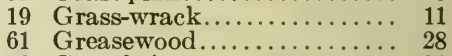

26 Greenbrier................... 21

18 Gromwell................... 63 


\section{$\mathrm{H}$}

PAGE

26,84

Hackberry .........

Hackberry, Western

Hair-grass

Hair-grass, Crested

Harbinger of Spring

Harebell. .

Hare's Ear, Arctic.

Haw, Black

Hawksbeard

Hawkbit, Annual.

Hawkweed

Hawthorn

Hazelnut

Hazelnut, Beaked

Heart, Floating.

Heath, Mountain.

Heather, American

Heather, False.

Heather, Ped.

Heather, Yellow.

Hedge-hyssop.

Hedge-hyssop, Clammy

Hedge-hyssop, Golden..

Hedge-nettle.

Hedge-parsley

Heliotrope

Hellebore, American IVhite

Hellebore, False.

Helleborine................. 23

Hemlock............8, 86, 87

Hemlock, Eastern.......... 8

Hemlock, Ground......... 8

Hemlock-parsley.......... 53

Hemp, Indian........... 56

Hemp, Water............. 28

Hempweed, Climbing......... 79

Hickory ...........26, 84,86

Hill-lettuce................ 74

Hog-peanut............... 47

Hole-pod............... 42

Holly................... 34

Holly, Mountain........... 34

Hollyhock, Wild ........... 43

Honewort................ 53

Honey-locust.............. 34

Honeysuckle............. 70

Hop-tree................ 48

Horehound, Water............ 66

Hornbeam.............29, 8

Hornwort.............. 26

Horse-balm.............. 66

Horse-gentian............. 70

Horse-mint, Prairie........... 66

Horseweed ............... 79

Hound's-tongue............ 63

Hound's-tongue, Northern... 63

Huckleberry ..........59, 84

Hutchinsia, Spreading...... 42

Hyacinth, Wild........... 21

Indigo, False......

\section{I}

Indigo, White

Indigo, Wild

(n)

Indigo, Yellow. .

Inkberry ..................

Iris.

Iron-plant. . . . . . . . . . .

Iron-weed

Iron-weed, Prairie............

Ironwood.

Ivy, Poison

J

Jack-in-the-pulpit

Jacob's Ladder.

Jewel-weed.

47

12
PAGE

M

Page

Jewol-weed, Spurless.

34 Madrona

Juneberry

June-grass. .

45, 84 Maids, Red

84 Mallow, False

Juniper, Common............. 87

Mallow, Fal

Mandrake, Wild ............ 48.38

Manna-grass............ 18

K Maple.

62 Maple, Broad-leaved .......... 33

Kidney-leaf

Maple, Manitoba.

Kidney-saxif

Knotweed.

49

Knotweed, Arctic............... 28

Knotweed, Virginian........ 28

Maple, Silver.

Maple, Sugar.

Maple, Vine.

Mare's Tail

Marigold, Fastern Marsh.

Marigold, Marsh

Labrador-tea

\section{$\mathbf{L}$}

Labrador-tea, Broad-leaved.

Lace-pod

59 Marigold, Yellow Marsh

59 Marigold, Water.

.............. 42 Marram-grass..

Ladies Tresses........... 23 Marsh-grass

Lady's Mantle.

Lady's Slipper.

Larch.................... 84

Larkspur.................. 37

Laurel.................... 58

Laurel, Mountain............ 58

Laurel, Pale............... 59

Laurel, Sheep............... 59

Laurel, Sticky............. 34

Lead-plant. . .

Leafcup

Leather-leaf..............

Leatherwood.................

Leopard's Bane..............

Lettuce.

Lettuce, Large-flowered Blue

Lettuce, Miner's.............

Lettuce, Tall Blue...........

Licorice, Wild ................

Lilaeopsis.

Lilaeopsis, Eastern

Lilaeopsis, Western.

Lily............

(n.

Lily, Sand.

Lily-of-the-valley, Wild.....

Lion's-heart, Eastern........

Lion's-heart, Western......

Lips, Blue.

Liver-leaf.

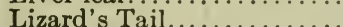

Lobelia.

Lobelia, Water.

Loco-weed

Loco-weed, Yellow

Loiseleuria, Trailing

Loosestrife, Fringed

Loosestrife, Tufted

Loosestrife, Winged

Loosestrife, Yellow

Lotus, American..

Lousewort.

Lousewort, Purple

Lousewort, Swamp

Lovage.

Lovage, Scottish.

Love-grass.

Lungwort.

Lungwort, Lance-leaved

Lungwort, Sea..

Lupin.

Lupin, Wild.

64 Lyme-grass, Sea.

Lyme-grass
Marsh-elder, Burweed..........

Marsh-pennywort......... 53

Marsh-pennywort, Roundleaved

May-apple.

Mayflower, Eastern.......... 21

Meadow-beauty........... 35

Meadow-grass............ 19

Meadow-grass, Tall........ 84

Meadow-parsnip.......... 53

Meadow-parnsip, Early...... 53

Meadow-rue...............

8 Meadow-sweet............ 45

6 Melic-grass.............. 18

Mercury, Three-seeded...... 27

4 Mermaid-weed............. 26

39 Milk-vetoh.............. 47

74 Milkweed............... 62

7 Milkweed, Four-leaved..... 62

53 Milkweed, Green........... 62

53 Milkweed, Showy......... 62

21 Milkweed, Whorled........... 62

21 Milkwort.............. 35

21 Milkwort, Fringed........... 35

34 Milkwort, Whorled......... 35

1 Millet-grass.............. 18

66 Millet, Indian............ 18

66 Mint................. 66

68 Mistletoe, Dwarf ............ 25

37 Mistletoe, Eastern Dwarf.... 25

26 Mitrewort............... 49

71 Mitrewort, Naked.......... 49

71 Mitrewort, Two-leaved...... 49

47 Mcck-orange............. 49

47 Monkey-flower................ 69

59 Monkey-flower, Cut-leaved.. 68

60 Monkey-flower, Square-stem-

34 Monkshood...................... 37

60 Moonseed .................. 34

56 Moss-heather............. 58

38 Moss pink.............. 64

69 Mountain-ash............. 45

69 Mountain-ash, Sharp-leaved.. 45

69 Mountain lover............ 34

Mountain-mint............ 66

53 Mountain-pink........... 60

18 Mountain-rice.................. 18

63 Mountain-sorrel............. 28

63 Mousetail.................. 37

87 Mudwort.................. 69

47 Mugwort................. 78

47 Mulberry................. 26

18 Mulberry, Red............ 84

87 Mule-ears................. 79

84 Musk-plant.............. 69
38,53

4 Mermaid, False........... 34

33 Milkweed, Green-flowered... 62

60 med 
MAGE

MLuskrat Potato

Musk-root.

Mustard.

Myrtle, Bog.

\section{$\mathrm{N}$}

Nannyberry...

Needle-grass

Nettle.

Nettle, False.

Nievitas.

Nightshade, Cut-leaved.

Nightshade, Enchanter's. .

Ninebark....

Nut-grass...

Nut-rush.

\section{$\mathrm{O}$}

Oak,

Oak, Chestnut

Oak, Garry....

Oak, Red.

Oak, White.

Oat.

Oat, False

Oat-grass.

Ocean Spray

Old Man Root.

Onion.

Orache.

Orchid, Hooded.

Orchid, Phantom

, Round-leaved....... 23

, Whorled.

Oregon-grape.

Ox-eye.

\section{$P$}

Paint-brush, Indian

Painted-cup............... 68

Painted-cup, Scarlet......... 68

Panic-grass................ 19

Papaw, North American....33, 84

Pappus-grass, Arctic......... 18

Parsley, Forked............ 53

Parnsip, Wild.............. 53

Parsnip, Mountain Wild...... 53

Partridge-berry........... 71

Partridge-foot.

Pasque-flower

Pea, Beach.

Pea, Veined.

Pear, Prickly

Pear, Smooth-fruited Prickly

Pearlwort.

Pellitory

Pennyroyal, Eastern.............. 66

Pennyroyal, False.

Pennyroyal, Mock

Pennyroyal, Narrow-1.

Pepper-grass.............. 42

Phlox.

Phlox, Annual.

Phlox, Blue.

Phlox, White Prairie.........

Physic, Indian............... 45

Pickerel-weed.

Pigmy-weed.

Pigweed.

Pigweed, Winged.

Pimpernel, False.

Pimpernel, Yellow.

Pine.

Pine, Pitch.

Pine, Prince's

Pine, White.

8

85 Pine, Yellow.

PAGE

Pineapple-weed............... 79

Pine-drops.

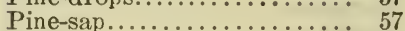

Pine-sap, Crownless........... 57

Pin-weed..................... 43

Pipe, Indian

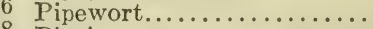

Pipsissewa....

Pitcher-plant.

\section{Plantain.}

Plantain, Indian

44

Plantain, Pale Indian........

Plantain, Tuberous Indian. .

Plum.

Plum, Indian.

Pokeweed.

$\ldots \ldots 26$

Pondweed, Fennel-leaved..... 85

Pondweed, Horned.................

Popcorn-flower.............. 64

Poplar...................29, 86

Poppy................... 47,83

Poque.................67, 83

Potato-vine, Wild.........................

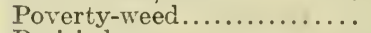

Prairie-bean.

Prairie-clover

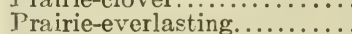

Frairie-parsley.

Prairie-smoke.

Prairie-star. .

Prickle-fescue.

Primrose.

Primrose, Evening.............

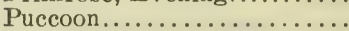

Puccoon, Hoary. ............

Purslane, Marsh............ 51

Putty-root............... 23

\section{Q}

Queen-cup.

Quillwort, Flowering............

\section{$\mathrm{R}$}

Rabbit-brush. Rabbit-brush, Prairie....... Ragweed.

Ragweed, Great................

Ragweed, Prairie...............

Ragweed, Tansy-leaved.....

Ragwort.

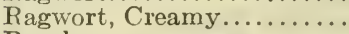
Raspberry

Rattle, Northern Yellow...

Rattle, Yellow..............

Rattlesnake-plantain.........

Rattlesnake-root.

Rattlesnake-root, Glaucous .

Ray-pimpernel.

Rayweed, Dotted

Rayweed, Eastern Dotted...

Redbud.

Redroot.

Reed, Indian.

Reed-grass

Reed-grass, Wood.............

Reed-mace.................

Rhododendron

Rhododendron, Dwarf...... Rhododendron, Early

Flowering.

Rhododendron, Tail............

Rhododendron, Western......
Rabbit-brush, Four-flowered
$\mathrm{R}$

PAge

Rhododendron, White-

flowered............... 59

Rib-sedge............... 13

Rice, Wild.............19, 85

Rice-root................. 21

River-cress.............. 42

River-weed.............. 26

10 Rock-cress............... 41

7 Rock-cress, Arctic.......... 41

Rocket, Sea............ 41

Rock-pink.............. 39

Rose................. 45

9 Rose-mallow............. 43

9 Rosemary, Wild............ 58

4 Rose-pink................ 61

5 Rose-pink, Square-stemmed. 61

Rosin-weed.............. 79

Rosin-weed, Dock-leaved.... 79

Rosin-weed, Whorled........ 79

Round-pod............... 41

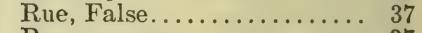

Rue-anemone.................. 37

Rush................ 85

$\mathrm{S}$

Sage-brush............ 78

Sage-brush, Common.................... 78

St. John's Wort........... 34

47 St. John's Wort, Marsh...... 34

79 Salal.................. 58

53 Salt-grass............... 18

45 Saltwort, Prickly............ 28

49 Sand-bur...............18, 73

18 Sand-cherry, Western......... 45

60 Sand-grass, Awned........... 19

51 Sand-grass, Awnless......... 18

63 Sand-grass, Big............84, 87

3 Sand-puffs................. 25

Sand-spurry.............. 40

Sandwort................... 40

Sanicle.................. 53

Sarsaparilla................... 51

Sarsaparilla, Bristly....... 51

Sarsaparilla, Wild.......... 51

21 Sassafras................. 86

10 Satin-grass...................... 18

Saw-wort.................. 79

Saxifrage............... 49

78 Saxifrage, Bulbous......... 49

79 Saxifrage, Eastern Golden... 49

78 Saxifrage, Golden............ 49

73 Saxifrage, Purple........... 49

73 Scale-sedge.................. 13

73 Scorpion-grass............. 64

73 Scorpion-grass, Opposite-

leaved ................ 63

79 Scorpion-weed............... 62

83 Scurvy-grass............... 41

69 Sea-angelica.............. 53

69 Sea-angelica, Eastern.......... 53

23 Sea-angelica, Western........ 53

74 Seablite.................. 28

74 Sea-lavender................ 56

60 Sea-milkwort............. 60

78 Sea-pink................... 56

78 Sea-plantain................. 56

34 Seal, Golden............37, 86

34 Seed-box..................... 51

19 Seed-box, Many-fruited....... 51

18 Seed-box, Yellow............ 51

18 Service-berry............... 45

18 Sheep-sedge............... 85

11 Sheep's Fescue............... 84

59 Shore-glehnia............... 53

59 Shore-weed................ 56

Short-husk, Bearded......... 18

59 Silver-berry.............26, 84

59 Silver-green.............. 78

59 Single Beauty............ 57 


\section{PAGE}

\section{$\mathrm{S}$}

Skeleton-weed.

Skeleton-weed, Purple........

Skullcap.

Skunk-cabbage, Eastern....

Skunk-cabbage, Western.....

Skunk-weed

Skunk-weed, Prairie.........

Skunk-weed, Small-flowered.

Slough-grass.

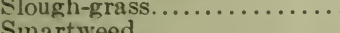

Snake-mouth..................

Snake-root............37,

Snake-root, Black...........37,

Snake-root, Seneca..........35, 85

Snake-root, White......... 78

Sneezeweed

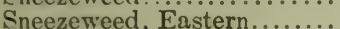

Snowberry..................

Snowberry, Creeping........ 59,

Solomon's Seal.

Solomon's Seal, False.........

Sorrel....................

Spear-grass.................

Spear-grass, Smooth.........

Speed well.

Speed well, Marsh.............

Spice-bush.

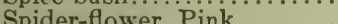

Spike-grass................

Spikenard, American.........

Spike-rush.

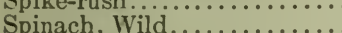

Spring Beauty.............

Spruce............. 86 ,

Spruce, White.............

Spurge.

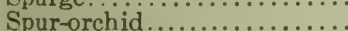

Squaw-root.................

Squaw-weed...................

Staff-tree.

Star, Blazing..............21,

Star, Shooting.................

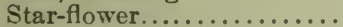

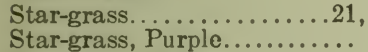

Star-grass, Woolly...........

Star-tulip

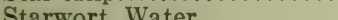

Steeple-bush..............

Stick-leaf.

Stickseed ..................

Stickseed, Forked............

Stitchwort................

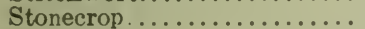

Strawberry................45,

Strawberry, Barren......... 45

Strawberry-blite ............ 28

Strawberry-bush.............

Sumac.

Sumac, Dwarf.................

Sumac, Fragrant............

Sumac, Scented.............. 35

Sumac, Smooth........... 35, 8

Sumac, Staghorn.........35,

Sumac, White..............

Sundew....................

Sundew, Round-leaved.......

Sunflower.

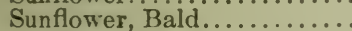

Sunflower, Flat-seeded........

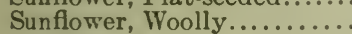

Surf-grass.................

Swamp-candles..............

Swamp-sedge, Tall...........

Sycamore.
$\mathrm{T}$

4 Tamarack

Tansy

Tar-weed

Tar-weed, Clustered

Tar-weed, Opposite-leaved..

Tar-weed, White-rayed.

Tassel-pond weed

Tea, New Jersey

18 Tear-thumb.

Thistle.

Thistle, Edible

Thorough-wax.

Thoroughwort

Tickseed.

Tickseed, Garden.................

Tickseed, Lance-leaved........

Tickseed, Stiff...............

Tickseed, Tall

Tick-trefoil

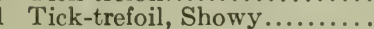

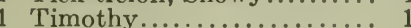

Tinker's weed.................

9 Toadflax.

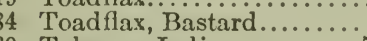

69 Tobacco, Indian...........71, 86

69 Tobacco, IVild

38 Tobacco-root.

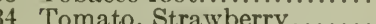

84 Toothwort.

1 Toothwort, Cut-leaved.......

Toothwort, Two-leaved.....

Townsendia.

9 Townsendia, Biennial.........

Townsendia, Dwarf.

Trefoil, Bird's-foot.

Trumpet-creeper.

Tulip.

Tulip-tree. .

Tumble-grass, Prairie..........

Turnip, Indian...............

Turtle-head.

Turtle-head, Eastern.....................

60 Turtle-head, Western........

Tussock-grass. .

Twayblade.

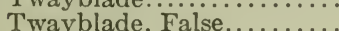

Twig-rush..................

Twinberry, Black...........

Twin-flower.

Twin-leaf. .

Twisted-stalk ..........

Umbrella-plant.

Umbrella-plant............

8

Valerian

\section{$\mathrm{V}$}

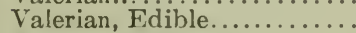

Valerian, Western.

Vanilla-leaf

Venus's Looking-glass..........

Vervain.

Vervain, Blue

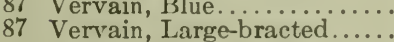

34 Vervain, Nettle-leaved......

34 Vetch.

79 Vetch, Pale.

79 Vetchling.

79 Violet.

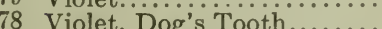

10 Violet, Green..................

60 Virgin's Bower.

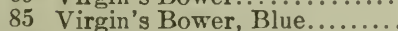

Virgin's Bower, White.......

66
PAGE

IV

PAGE

87 Wake-robin

22

9 Wake-robin, Western......... 22

86 Wall-flower.............. 42

79 IValnut.................26, 8

79 Walnut, Black............ 26

79 Wapato................. 85

11 Water-blinks.............. 39

34 Water-celery.................. 53

28 Water-cress................ 42

78 Water-hemlock............ 53

83 Water hemlock, Bulb-

bearing.

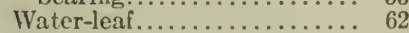

Vater-leaf, Appendaged....... 62

Water-leaf, Broad-leaved.... 62

Water-leaf, Virginian........ 62

Waterlily, Eastern Yellow... 85

8 Waterlily, Tuberous White... 38

Waterlily, Western Yellow.38, 85

7 Vaterlily, White........... 38

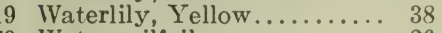

70 Water-milfoil................ 26

69 Water-nymph.............. 10

26 Water-parsnip................. 53

86 Water-plantain............... 10

64 Water-plantain, Dwarf....... 10

83 Water-shield...............38, 85

64 Water-stargrass............. 10

41 Water-weed.................... 10

42 Water-willow.............34, 56

41 Water-wort................... 34

9 Wedge-grass................ 19

9 Weed, Clammy............ 34

9 Wheat-grass................ 18

7 Wheat-grass, Slender....... 84

6 Whisker-grass............ 19

6 Whitlow-grass............. 42

8 Whitlow-wort............. 26

19 Whorl-grass, Water........... 18

12 Wicopy................... 26

68 Willow................29, 86

8 Willow-herb................. 50

8 Willow-herb, Yellow......... 50

84 Wind-flower............... 37

3 Winterberry.............. 34

Winter-cress............... 41

3 Winter-fat................... 28

70 Wintergreen, ............57, 58

70 Wintergreen, Chickweed..... 60

38 Wintergreen, Leafless........ 57

21 Witch-grass ............... 19

Witch-hazel................. 84

Wolfberry................ 70

28 Wood-mint................ 66

25 Wood-nettle.................. 27

IVood-rush..............10,85

Wood-sage.................. 66

72 Wood-sorrel..................... 34

72 Wood-sorrel, White.......... 34

85 Woolly-weed.............. 85

38 Wormwood................ 78

71 Woundwort........................... 66

66 IVoundwort, Marsh............. 66

66 Wrapper-sedge............ 13

66

47

47

47

48

21

48
37

37
37

37

7 Yew. Western............... 8

Y

Yamp................. 53

Yam-root, wild............ 10

Yarrow.................... 78

Yarrow, Woolly............ 85

Yerba Buena............. 66

49 


